Historic, Archive Document

Do not assume content reflects current scientific knowledge, policies, or practices. 



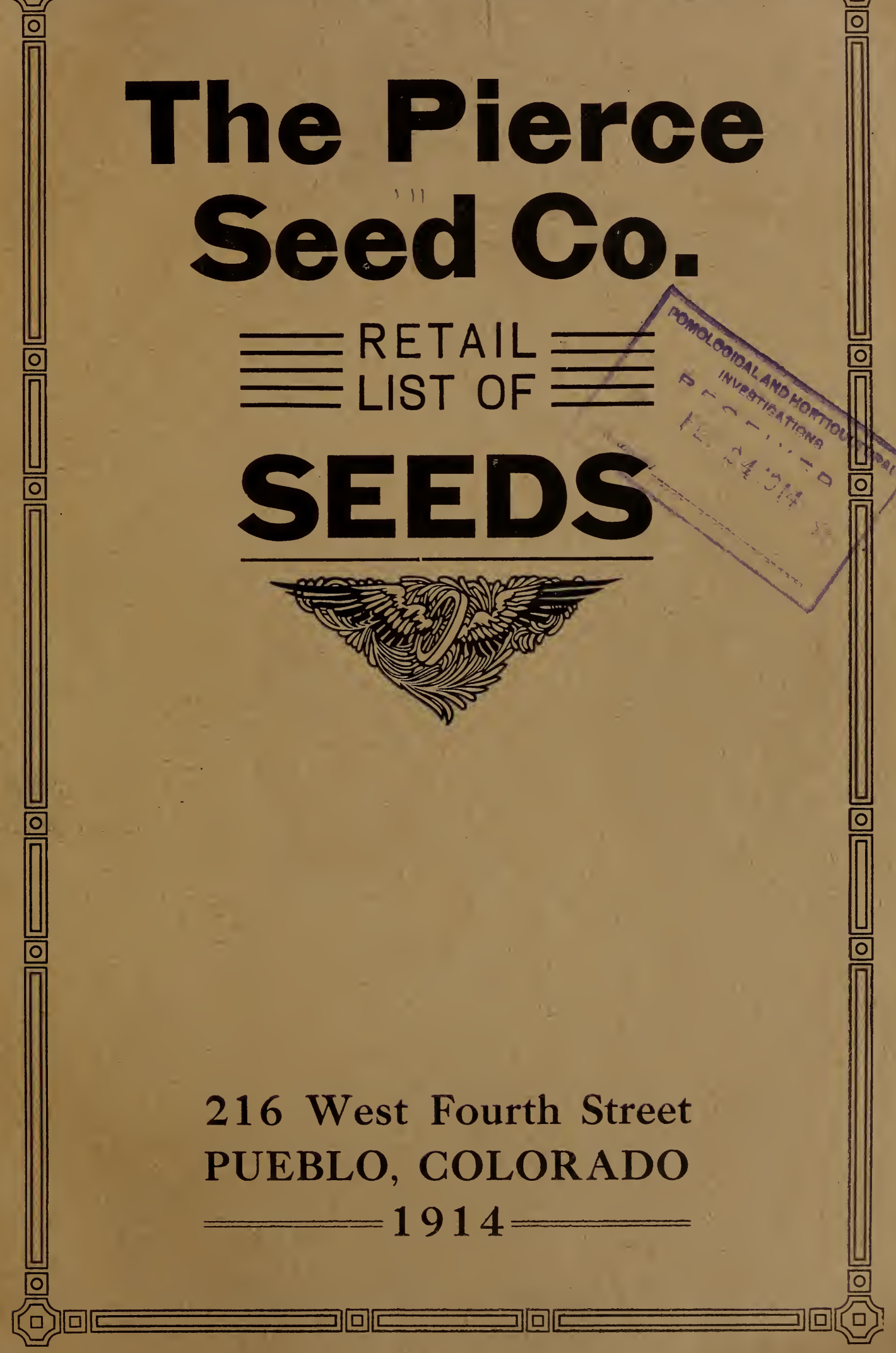




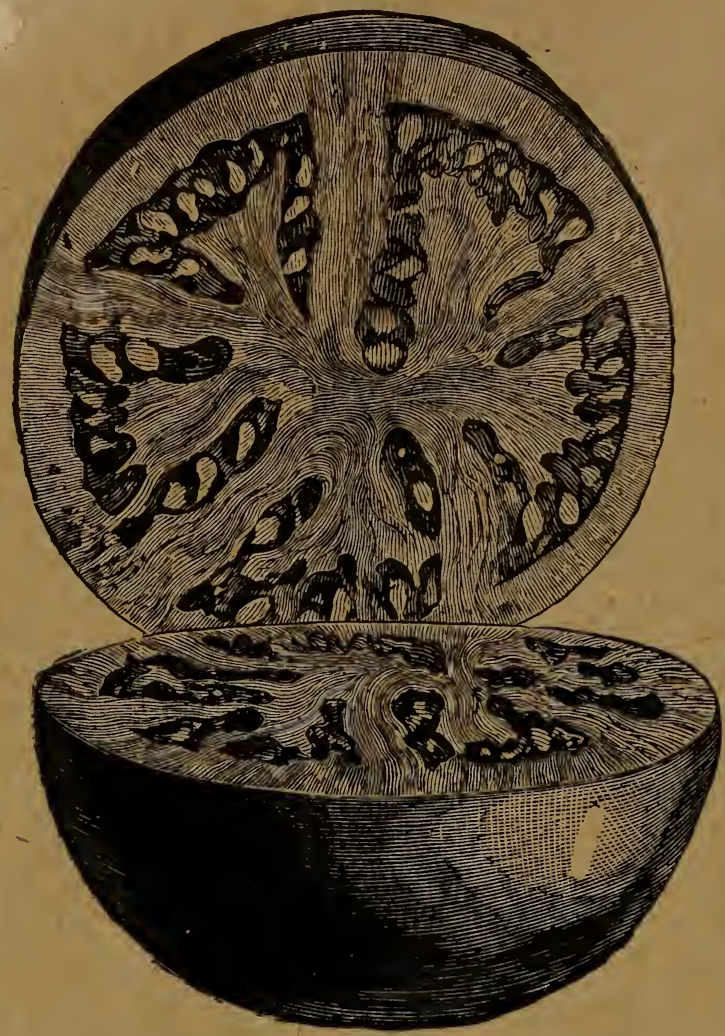

\section{The Three Best} Early Tomatoes SPARKS' EARLIANA

Very early. The fruit is unusually solid, but few seeds, and attractive red color, very productive.

\section{CHALK'S EARLY JEWEL}

Some consider this variety the best early tomato. It is large, smooth, fine flavor, bright red, strong grower and prolific.

Price, each per oz. 20c postpair

\section{JUNE PINK}

One of the early choice tomatoes, enormous bearer, fruit is of medium size, smooth and attractive shape, in c- or a pleasing pink. Oz. 30c. After three years trial these three have give $n$ the best results.

TRY BONNIE BEST and EARLY MICHIGAN. - Two good early Tomatoes that may suit your soil better than some others you have tried. Oz. 30c

\section{GRIMM ALFALFA}

Withstands drouth and frost better than any other variety.

Try a few pounds and get a start. See description on page thirty-four.

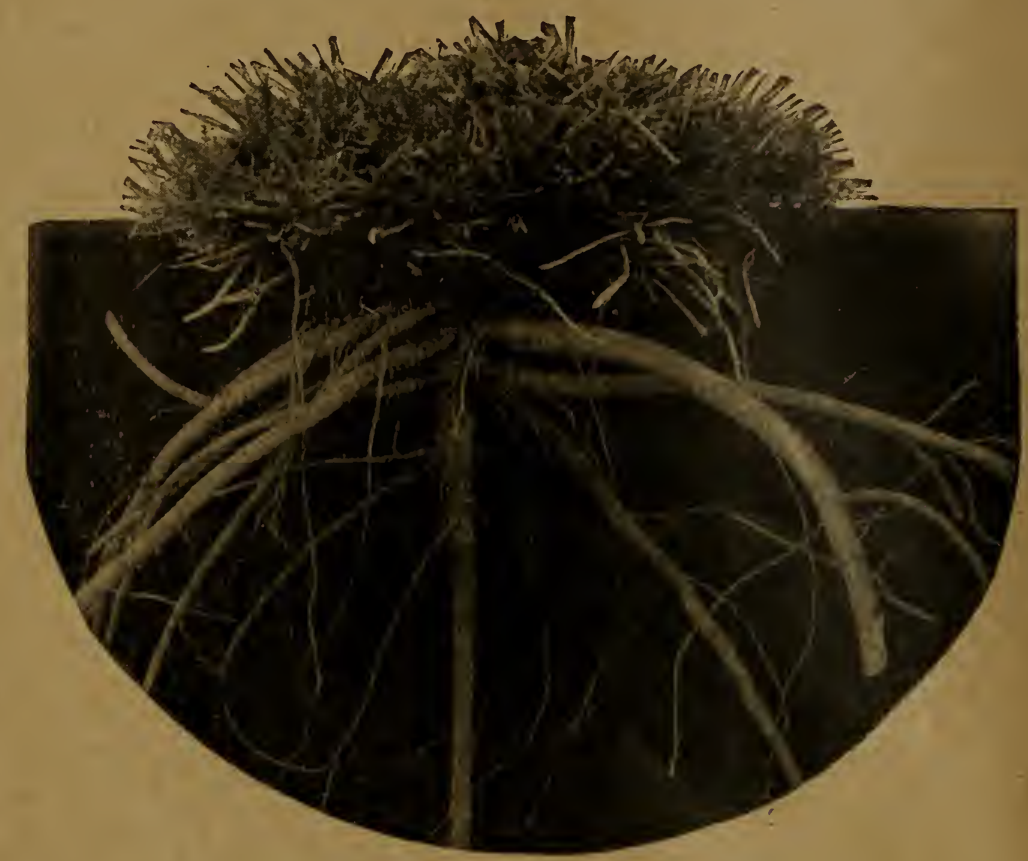




\section{ORDER SHEET}

Please be particular to Write Your NAME AND AdDREss Distinctly aNd IN Full with each order. Be particular to give express office, as some orders can be sent cheaper by prepaid express than by mail. ORDER EARLY, so that order can be filled before stock is broken.

No Goods Sent C. O. D. Our Terms are Cash with All Orders

\section{THE PIERCE SEED C0., Pueblo, Colo.}

\section{Please Forward the Following Order :}

216 WEST FOURTH STREET
Your Name

Postoffice

Express Office

County

State
Amt. Enclosed, P.O. Order, \$

“ “ Postal Note, $\$$

“ “ Draft - \$.

“ “ Cash - $\$$

Total, $\$$

Date $191 \ldots$

THE PIERCE SEED CO. gives no warranty, express or implied, as to description, purity. productiveness or any other matter of any seeds or bulbs they send out, and they will not be in any way responsible for the crop. If the purchaser does not accept the goods on these terms they are at once to be returned.

THE PIERCE SEED COMPANY.

Lbs.

0z. Pkts.

Name of Seeds or Other Articles Wanted

Price 


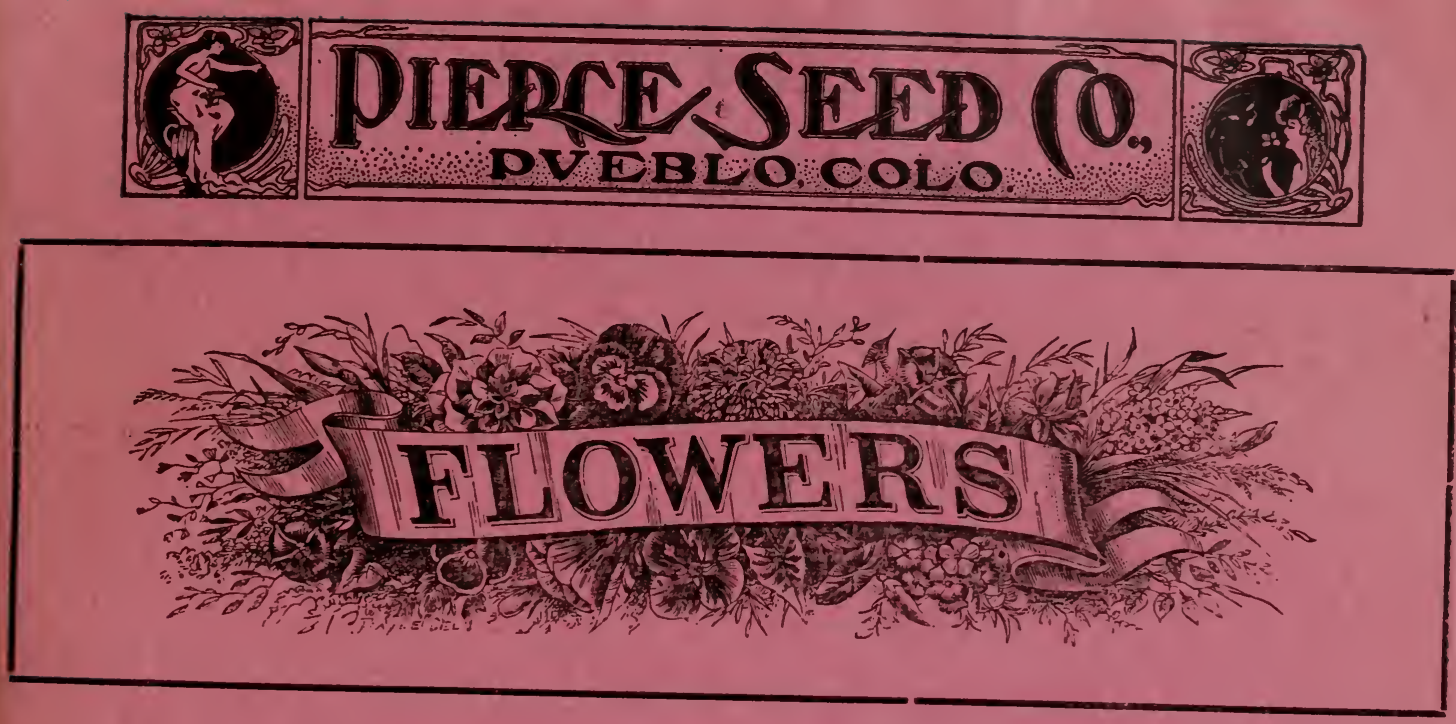

\section{SUMMER FLOWERING BULBS}

Should be put in the ground as soon as the season will permit. A light covering of old straw or litter will be a good protector from early changeable wcather. If you have never grown flowering bulbs, try them this season, as they are much more satisfactory than growing flowers from seeds.

MADERIA-A beautiful, showy vine, $5 \mathrm{c}$ each.

\section{Double Pearl Tuberose}

Height, twenty to twenty-four inches. Flower louble and large, and very fragrant. Price Extra large size bulbs, $10 \mathrm{c}$; three for $25 \mathrm{c}$, postpaid.

\section{GLADIOLI}

White and light shades, pink and rose, scarlet and red striped and varigated. Price: 5c each; 40c per dozen, postpaid.

AMERIOA-Conceded to be one of the finest ra. rieties for cutting or bedding. Color a beautiful soft flesh pink. 5c each; 50c per dozen.

BRENCHEYENSIS - A most beautiful vermilion scarlet. $5 \mathrm{c}^{-}$each; $50 \mathrm{c}$ per dozen.

GANDAVENSIS-Fine flower, large and beautiful color. Mixed, 40c per dozen.

LEMOINES -Very fine, choice mixed. 40c per doz. This stock is the finest grown, and you will be more than pleased if you blant our collection.

\section{CANNAS}

The most desirable bedding p'ant; we offer some of the most popular rarieties. Price, 10c each; per dozen, $\$ 1.00$.

AUSTRIA-Green foliage of remarkably strong growth; flowers very large, color pure yellow with light klotches of red in the throat. 5 feet.

DUKE OF MARLBOROUGH-Dark, rich velvety maroon. One of the deepest and richest colored cannas. 4 feet.

PRESIDENT McKINLEY - Brilliant crimson with cearlet shading. 3 feet.

ALSACE-Creamy white. $31 / 2$ feet. PRESIDENT CLEVELAND - Largest flowers,
bright orange flowers. 3 feet.

ITALIA-Green foliąe, bright red, bordered with golden yellow. 3 feet.

BLACK PRINCE-Intense dark relvet maroon. strong grower, ceep green leaves edged with purple. 3 to 4 feet.

WYOMIXG-Called King of the Giants. Rich purple foliage; abore this are borne plumes of massive orarge colored blossoms. 7 feet.

MIXED VARIETIFS- $75 \mathrm{c}$ per dozen.

WINTER AND EARLY SPRING FLOWERING BULBS, SUCH AS HYACINTHS TULIPS, CROCUS, NARCISUS, PAPER WHITE AND OTHER VARIETIES, CHINA SACRED LILY, TEMBER, WRITE FOR. PRICE LIST. AND FREESIAS, WTLL BE READY ABOTT SEP. 


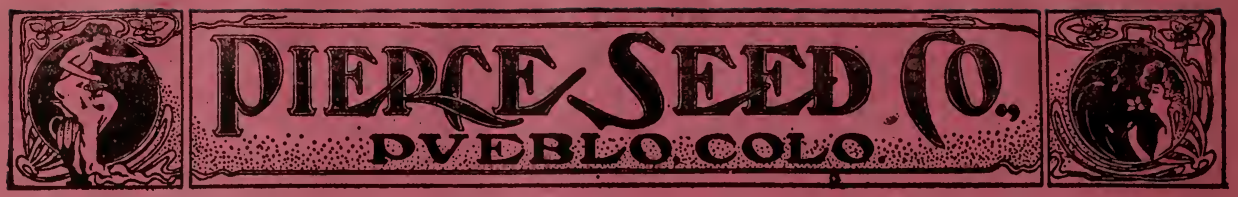

DAHLIAS

CULTIVATION-While the Dahlia is one of the easiest of all flowers to cultivate, it by no means follows that it requires no attention. In fact, no tower cultivated will give such a generous response to good cultivation as the Dahlia. Deep and thorough stirring of the soil during the early growth of the plant is indispensable to success T'he Dahlia, with but few exceptions, should be given an open, sunny situation for at least a portion of each day. It is a rank feeder and should be given a rich soil and kept free from grass and weeds. Cultivation should cease when the blooms appear. After this a liberal supply of water in dry weather will be all they require. Plant the bulbs two or three feet apart, according to the size and habit of the plant. The bulbs should be planted about three or four inches below the surface, lay. ing the bulb on its side.. Varieties growing three feet in height should be tied to stakes to prevent falling. Plant about the first of April in this latitude.

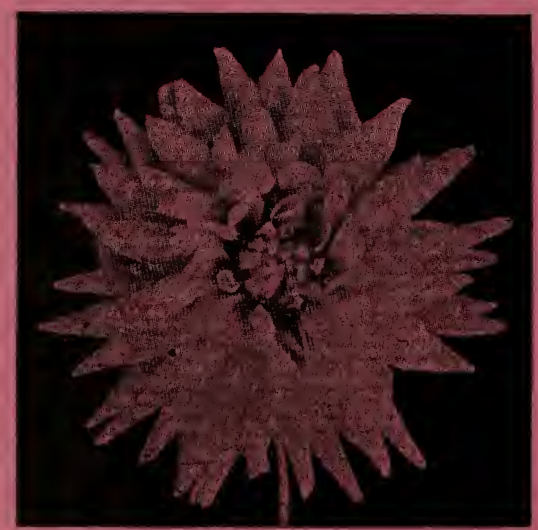

\section{NOVELTIES.}

Height 20c each; $\$ 2.00$ per dozen.

Feet

YELLOW DUKE-A showy variety in form very much like the Grand Duke Alexis, but with far better stem. Color clear bright yel-

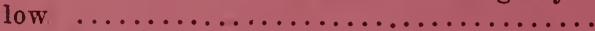

DOUNTRY GIRI_-Base of petals golden yellow, suffused with salmon rose. Flowers very large and perfect in form. An exceptionally fine Dahlia. ................ $31 \frac{1}{2}$

KRIE ivHILDE - A beautiful cactus form, with long pointed petals. Color, a beautiful shell pink, shading to white at the center. Undoubtedly this variety is the best of its

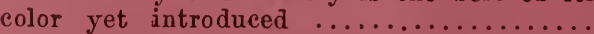

MME. DAEL-An immense decorative dahlia, entitled to first place among all the shell pinks. It is very large and yet chaste in form,;stems are exceptionally long. Color, soft shell pink. A noble dahlia ..........
Feet High

Approximate

COUNTESS OF LONSDALE-The freest flowering Cactus Dahlia in the collection, and perfect in form. Color, an exquisite shade of rich salmon with just a suspicion of apricot at the base of the petals. Towards the tips the color deepens gradually to the

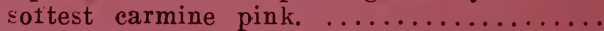

MRS. WINTERS-Its color is a pure waxy white, which shows no tint or variation in the strongest sunlight. Very free bloomer, producing flowers from 5 to 7 inches in diameter with beautiful pointed petals. About 3 feet high. It it the grandest of all

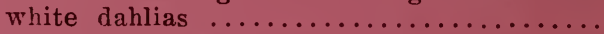

JACK ROSE (Decorative)-Dark crimson red. In color similar to the rose of this name. Flowers are large and full. Flowers well

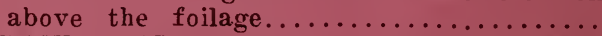

GRAND DUKE ALEXIS-Very large; its petals are beautifully quilled; color is pure white when slightly shaded, but overspread with delicate lavender when grown in bright sunlight

\section{DOUBLE VARIETIES}

Price, 15c each; $\$ 1.50$ per dozen, postpaid. A. L. CHAISE-Creamy white streaked with purple. Sometimes solid purple...........

CREAM OF THE VALEY-Creamy pink, shad ing to a crimson tip. Very large, stem long

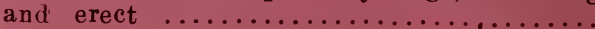

DREERS WHITE-Pure white resernbling in form the popular Grand Duke Alexis .......

THE BARON - A strong, robust grower. Bright yellow. Flowers sometimes tipped

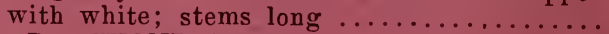

A. D. LIVONI-Rich pink; finely formed; $a$ very handsome flower $\ldots \ldots \ldots \ldots \ldots \ldots$.

BON TON-A fine ball shaped flower of a leep garnet red, sometimes tipped and

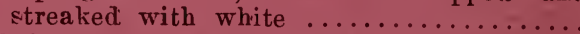

FIRE BALI, A most intense dark red with long stem $\ldots \ldots \ldots \ldots \ldots \ldots \ldots \ldots \ldots \ldots$

ALORY DE LYON-The largest white Dahlia in cultivation; almost round as a ball .....

KAISER WILHELM-One of the grandest flowers in eultivation; of immense size and perfect form; deep yellow, tipped and shaded with cherry red ................

LADY MILDMAY -A very beautiful flower, white ground, shaded to pink; very large

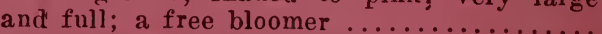

MISS DODD-Purest yellow of exquisite form and color; a remarkably handsome flower...

PJONEER-The nearest approach to a black Dahlia of any yet introduced. For com bined excellence it has no superior........

PURPLE GEM-Rich, royal purple, clear and constant; this variety is a decided improvement over all other varieties; a first class flower

SNOW-A beautiful pure white, long stems, excellent for cutting 


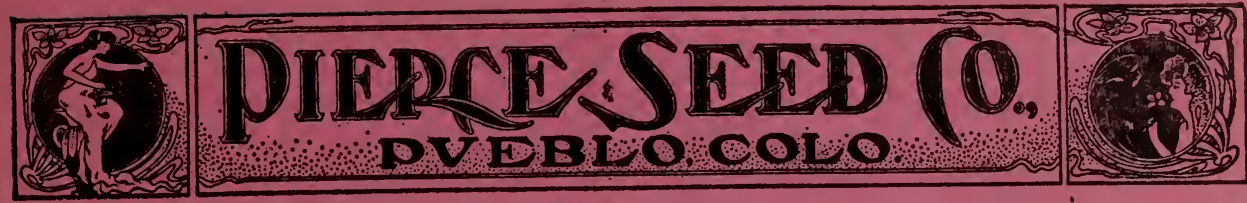

\section{DAHLIAS-Continued}

\section{CACTUS AND DECORATIVE VARIETIES.}

Cactus varieties have long pointed petals. The decorative types are distinguished by their broad flat petals. These two types are comparatively new and possess all the richness of color found in the older types, and surpass them in point of usefulnes for decorative purposes.

Approximate Feet High

MRS. BENNETT - Soft crimson, large and well formed. Petals broad and pointed...

DR. GATES (Decorative)-This new Dahlia is a lovely shade of shell pink, shading to blush at the base of the petals. As a vari-

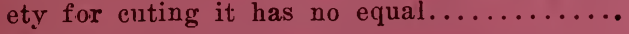

GENESTA - Rich orange bronze. A fine autumn sharle $\ldots \ldots \ldots \ldots \ldots \ldots \ldots \ldots \ldots \ldots$

GOLDEN SUN-A large massive flower. Golden yellow, shaded. Lighter in the center ..

GYPSY MAID-Orange scarlet petals. Long and pointed $\ldots \ldots \ldots \ldots \ldots \ldots \ldots \ldots \ldots$

EARL OF PEMBROKE (Cactus) - A grand Dahlia, looking more like a chrysanthemum; petals long and narrow; color rich dark pur-

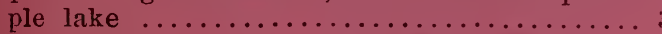

EUGENE TEELE-A very fine, deep scarlet. Produces in long stems; valuable for cutting

FLORADORA (Cactus) - A most valuable addition to the cactus list. A marvel of pro ductiveness and of exquisite form. Deep

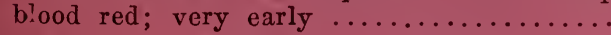

GEN. BULLER (Castus)-Cardinal with crimson shading. Each petal tipped with pinkish white. Stems long. An extra fine Dahlia..

GOLDEN TREASUFE (Decorative)-A beautiful burnt orange color; flowers large and

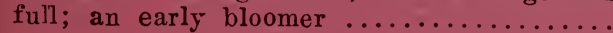

GRAND MOGUL (Decorative) - Intense scarlet, variegated with pure white, frequently a scarlet $\ldots \ldots \ldots \ldots \ldots \ldots \ldots \ldots \ldots \ldots$

JUANITA FORD (Decorative)-Flowers very large, borne on long stems. Color deep cardinal red. An excellent variety for cutting

\section{BOX COITECTION OE DAHLIAS FOR $\$ 1.00$}

These collections are put up in a neat telescope box packed ready to ship. 13 rarieties, unlabled. A wide range of colors, red, white, pink, yellow and variegated. No two alike, and all double.
Approximate

Feet High

MRS. A. PEART (Cactus)-Ivory white; a graceful flower; free and constant bloomer

MRS. HARTONG (Decorative)-Very large, exquisite form; color, light fawn, diffused with pink; handsome..$\ldots \ldots \ldots \ldots \ldots \ldots$.

HENRY PATRICK-Pure white; one of the very best. Flowers are very large. Stems long $\ldots \ldots \ldots \ldots \ldots \ldots \ldots \ldots \ldots \ldots$

IRS. LINDER (Decorative)-This new decorative Dabiia we consider one of the best. Its color is a beautiful creamy white, shading to blush pink. Of perfect outline .......

PRINCE OF ORANGE (Cactus) - A marvel of productiveness; plants nearly hidden with the large, well formed flowers; rarely a deformed flower seen; color, apricot, orange,

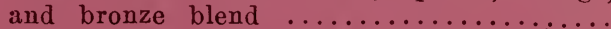

SPOTLESS QUEEN (Cactus)-Purest white, an excellent variety for cutting purposes .

STANDARD BEARER-Rich fiery scarlet; one of the very best $\ldots \ldots \ldots \ldots \ldots \ldots \ldots \ldots$

ZEPHYR (Cactus) - A light, feathery form of unique coloring; rosy pink, shading to heliotrope. An early and profuse bloomer 4 Price, Each, 15c; per dozen, $\$ 1.50$; postpaid. 


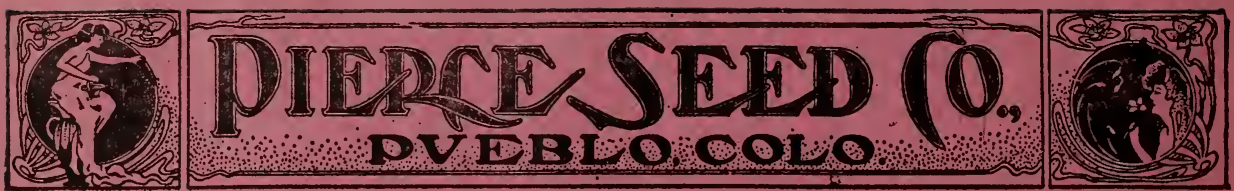

FLOWERING SWEET PEAS

PREPARING THE SOIL-Select a warm, sunny place, and if possible prepare the ground in the iall by a liberal application of well rotted manure. If your soil is adobe, use old coarse manure in the spring. Place the fine manure as much in the trenches as possible.

SOWING THE SEED-After you have the soil well prepared, make a trench six inches deep, sow the seed about one inch apart in the trench, and cover two inches. As the vines grow, draw the earth up to them until the ground is level or slightly lower between the rows. Lnother way: Make two trenches six inches deep from six to eight inches apart, and the double rows from eighteen inches to two feet apart, making the ground lower between the rows.

A FEW HINTS- Prepare the ground and get the seed in as early as possible

Have the ground moist (not soggy wet) when you sow the seed.

Do not irrigate until the plant is through the ground; sprinkle rows to keep the ground moist.

When nicely started, do not iet them want for water; sprinkle the vines two or three times a week, but not in the heat of the day.

A small quantity of fertilizer mixed with the ground in the bottom of the trench before planting is very beneficial, and the plant appreciates mulching.

Keep all flowers cut off if you want continuous bloom. When they go to seed, that ends flowers.

Owing to the short crop and high price of Sweet Pea Seed, we are listing only the very best of shades in the Grandiflora and Spencer types of Sweet Peas.

\section{DO NOT USE FRESH MANURE}

WHITE.

DOROTHY ECKFORD-The grandest pure white;

very fine; the largest white.

BLANCHE BURPEE-Pure white; immense size.

\section{LIGHT YELLOW, ORANGE OR SALMON.}

STELLA MORSE-Large flowers; a combination yellow and pink which is quite distinct and very attractive

HON. MRS. E. KENYON- This is the best yellow to date; large flowers, long stems and very prolific.

DORA BREADMORF-Buff tinged pink, large.

\section{I-IGHT SHADES OF RED.}

JANET SCOTT-Bright pink, large flowers; fine.

PRIMA DONNA-A clear pink, hooded, choice va riety.

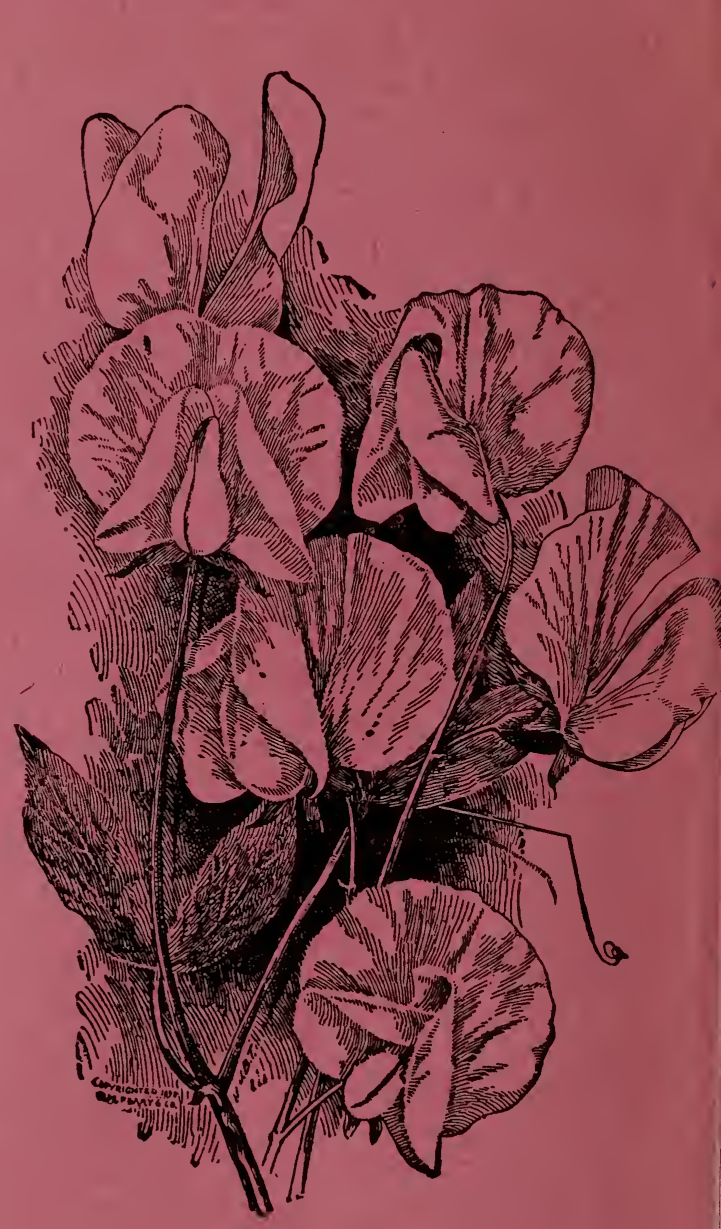

DARK SHADES OF PINK.

ROYAL ROSE-Fine deep rose colored.

\section{SHADES OF RED.}

PRINCE OF WALES-Rose crimson self color; very large and fine.

SALOPIAN-Brilliant scarlet.

KING EDWARD VII.-Bright red or crimson scarlet; very large, open form. 


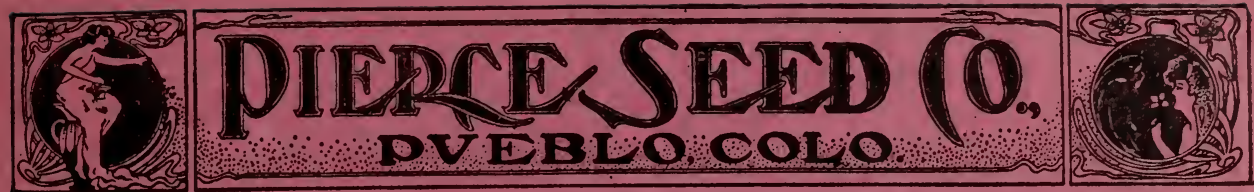

\section{FLOWERING SWEET PEAS}

\section{SOME OF THE MOST SATISFACT ORY VARIETIES GROWN.}

\section{RED AND WHITE, IIGHT WINGS.}

EXTRA EARLY BT'ANCIHE FERRY-Pink and white; extra early variety.

BLANCHE FERRY-Pink and white.

\section{SCARLET AND MAROON.}

OTHELLO-Very dark maroon; large size hooded form.

SHAZADA-Dark maroon with a tinge of purple in standard inner portion of wings.

\section{LAVENDER AND LIGHT BLUD.}

COUNTESS RADNOR-Delicate lavender.

LADY GRIESEL HAMILTON-Standard mauve, wings lavender; large size, hooded form; the largest and light shade of lavender.

\section{BLUE AND PURPIE}

BRILLIANT BLUE-Blue.

CAPTAIN OF BLUES-Purple blue.

NAVY BLUE-

\section{STRIPED AND VARIEGATED.}

AMERICA-Bright blood red, striped white.

Price: Ounce, 15c; $4 \mathrm{oz}$. of one kind for $40 \mathrm{c}$, on all separate colors.

ECKFORDS-Finest mixed, 15c oz.; 2 oz., 25c

PERENNIAL OR HARDY SWEET PEAS-Mixed. Oz., 15c.

SWEET PEAS-Postpaid at above prices.
NEW WAVED SPENCER TYPE SWEET PEAS

This class derived its name from Countess Spencer, the first one of this type discovered in 1902. This type has an upright, round standard from one and three quarters to two inches wide and is wavy and fluted at the outer edges. Its wings large, drooping and wavy at the outer edge. Vines thrifty and strong; long stems, and sometimes four blooms to the stem..

ASTA OHN- Waved Spencer. Large pure lav. ender with tint of pinkish rose. Oz.,45c.

BLANCH FERRY SPENCER - Standard bright crimson rose wings, white tinged with pink. Oz., $45 c$.

COUNTESS SPENCER - The original Spencer beautifully waved.. Very large, ciear bright pink. Oz., 30c.

DAINTY SPENCER-Waved Spencer. Large size. white with pink edge a little deeper on back of standard. Oz.., 30c.

KING EDWARD-Very large pure bright red or erimson scarlet. $\mathbf{O z}$., $35 \mathrm{c}$.

MRS. SANKEY - Waved Spencer type. Large size, pure white. Oz.., 40c.

OTHELLO SPENICER-Deep velvety maroon, the rery best maroon Spencer. Oz., 35c.

WHITE SPENCER - Very large, of the purest white. Oz॰, $40 c$

MIXED “SPENCER” SWEET PEAS-The above varieties of mixed Spencers. Oz., 35c. 


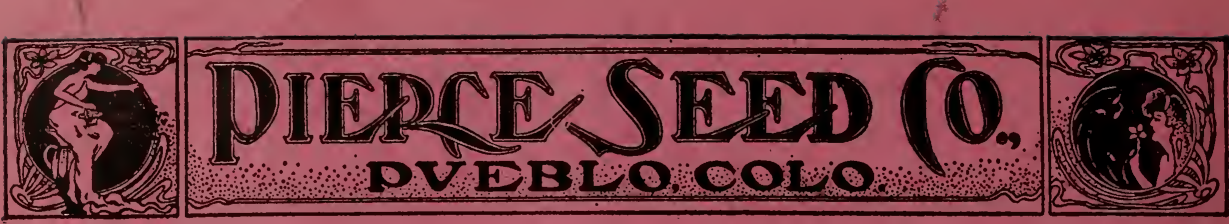

\section{Hardy Perennial Roots and Bulbs}

START A PERENNIAL FLOWER BED THIS SP RING AND EACH YEAR ADD A FEW MORE

VARIETIES AND SEE HOW SATISFACTORY THEY ARE.

\section{PEONIES}

(Hardy.)

\section{FESTIVA MAXIMA.}

A rare variety of great beauty, exceedingly showy and of large size; flowers perfectly double; pure white, flaked with crimson spots ifi center. each, $40 \mathrm{c}$.

AGIDA.

Early, brilliant deep red.

\section{ANDRE LAURIES.}

Late rose, long stems, violet red.

\section{HUMIE.}

Immense, late pink, cinnamon scented flower.

\section{L'ESPERENCE.}

Early fragrant pink, very large.

\section{QUEEN VICTORIA.}

Standard white, choice for cut flowers.

\section{VICTORIA TRI-COLOR.}

Outer petals pale rose, mottled with pink center over yellowish white, with a few red marks.

Price: Each, 25c; set of 6 for $\$ 1.00$

\section{WHITE.}

Un-named.

\section{DOUBLE RED.}

Un-named.

DOUBLE PINK.

Un-named.

Price: Each, 20c; 6 for $80 c$.

\section{HOLLYHOCKS}

\section{MAMMOTH DOUBIE FRINGED \\ "ALTEGHANY"}

The mammoth flowers are wonderfully formed of loosely arranged fringed petals, which look as if made from finest China silk; mixid colors; 10c each; $\$ 1.00$ per dozen.

\section{(Double Strong Field Roots.)}

The flowers, which are as elegant in shape as a Camelia, form perfect rosettes of the most lovely shades'; separate colors in red, white, yellow, pink and maroon. Price: $10 \mathrm{c}$ each; $\$ 1.00$ per dozen.

\section{PHLOX}

(Hardy)

Red, pink, white, lavender, lilac, deep purple, pale pink with red eye, pure white with pink eye, salmon scarlet, strong. healty roots; 10c each; $\$ 1.00$ per dozen, postpaid.

\section{GOLDEN GLOW}

\section{(Hardy)}

\section{DOUBLE RUDBECKIA.}

One of the brightest and most showy among the hardy plants, and of the earliest culture; grows four to five feet high, producing numerous sterns which are laden with double golden yellow flowers, in size and general appearance resembling a Cactus Dahlia. Price, $10 \mathrm{c}$ each; $\$ 1.00$ per dozen.

\section{BLEEDING HEART}

(Hardy)

Producing graceful sprays of heart-shaped link and white flowers; each, $25 \mathrm{c}$.

\section{COLUMBINE}

\section{ROCKY MOUNTAIN COLUMBINE ROOTS AQUILEGIA. (Hardy)}

Can be planted in the fall or early spring.Price, per root, postpaid, 10c to20c.

\section{IRIS}

\section{GERIMANICA.}

IRTS (Germanica)-Blue, bronze, lavender, pink yellow and creamy white; $10 \mathrm{c}$ each; $\$ 1.00$ per dozen.

\section{TIGRUM}

TIGRUM (Tiger Lily)-10c each; $\$ 1.00$ per dozen.

\section{SHASTA DAISY}

SHASTA DAISY-A mammoth new daisy, pro ducing pure white flowers with yellow center; 10c each; $\$ 1.00$ per dozen.

\section{ALASKA DAISY}

BURBANK'S ALASKA DAISY - Flowers four inches across. Excellent for cutting and will keep a full week in water. Keep the blossom buds cut off until the plants are well established. Plant in rich soil; give the plants lots of room and plenty of water. Strong plants, 15c each; $\$ 1.50$ per dozen. 


\section{Hardy Perennial Roots and Bulbs}

GYSOPHILA PANICULATA (Baby's Breath)A beautiful perennial, two or three feet in height; minute pure white flowers. For eutting purposes it is exquisite, especially in combina. tion with high colored flowers. Price 10c each.

GOLDEN ROD-A strong growing plant, producing rich golden yellow bloom in July and August. Price, 10c each.

HARDY ASTERS (Michaelmas Daisy)-Late flow. ering hardy plants giving a wealth of bloom at a season when most other harày flowers are past. We have three colors, blue, white, light lavender. Price, $10 \mathrm{c}$ each.

SWEET WILLIAM-A general favorite with all. Mixed eolors. Price, 10c each.

CARNATION (Hardy)-Mixed colors, from pure white to dark red. Price, 10c each.

\section{HARDY POMPONE CHRYSANTHEMUMS-They} are profuse bloomers and continue to flower long after other flowers are gone. Color, red, white, purple, yellow. Price, $10 \mathrm{c}$ each.

ORIENTAL POPPY-Perfectly iardy.. Its large orange searlet flowers make it one of the most showy of all plants; when cut before the sun strikes the flower in the early morning it will last a long time as a eut flower. Price $10 \mathrm{c}$ each.

PENSTEMON (Barbatus)-A hardy native penstemon producing brilliant searlet flowers and long spikes. Price, 10c each.

\author{
HARDY VINES.
}

(LEMATIS (Paniculata)-A vine of very rapil growth, with handsome, clean, glossy green foliage. Flowers of medium size, pure white, borne in immense sheets of a most delicious and penetrating fragrance. The flowers appear in September. Should be provided with trellis or something to elimb on as soon as it starts its growth. Price, 2 year old, $25 \mathrm{c}$ each.

CLFMIATIS (Jackmani) - This variety with its strong, healthy growth and rich, deep velvaty purple flowers is the most satisfactory of its class. Should be pruned early in the spring. Price, $75 \mathrm{c}$ each.

CINNAMON VINE ROOTS-This is a rery rapid growing vine when roots are well established. Foliage bright glossy green, small white flowers, very fragrant. Price, $10 \mathrm{c}$ each; 3 for $25 \mathrm{c}$.

HONEYSUCKLE (Halleana)-A vigorous grower. Flowers yellow and white, very fragrant. Price, $25 \mathrm{c}$ each.

HONEYSUCKLE—Searlet Trumpet. A rapid growing Honeysuckle, with clusters of trumpet shaped flowers. Price, 25c each.

WISTERIA-A rapid climber, producing long sprays of purple flowers. 2 yr. old roots, $25 \mathrm{c}$ each

Manual on the Peony, by C. S. Harrison. Price, $25 \mathrm{c}$.

Manual on the Dahlia, by W. W. Wilmore. Price, $25 \mathrm{c}$.

Manual on the Phlox, by C. S. Harrison. Price, $25 \mathrm{c}$.

With $\$ 2.00$ worth of hardy plants or bulbs we will give one of the three Manuals offered on this page, provided it is requested at time of purchase.

We Prepay Postage on Garden and Flower Seeds except Peas, Beans ond Corn. 


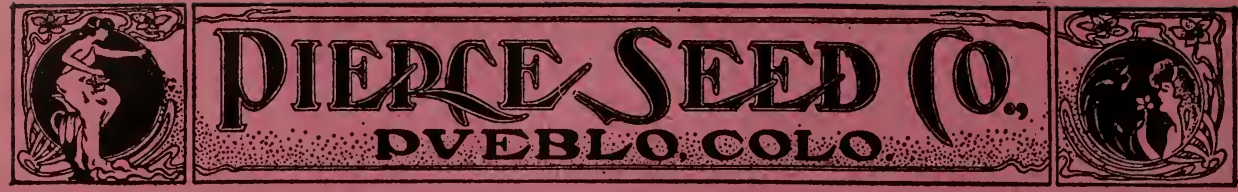

\section{FLOWER SEEDS}

Flower Seeds sent by mail on receipt of price. Full cultural directions on each package. In our list you will find $A, B$, or $P$, to each variety. A for ANNUALS, which grow, bloom and die the first year from seed. B for BIEN:NIALS, bloom the second year from seed, then die; though many, it sown early in the spring, will flower the first year. $\mathrm{P}$ for PERENNIALS, usually bloom the second

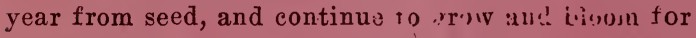
many years; some will also bloom the first year if sown early.

Alyssum, Sweet (A) white.

Acrolinub (A) everlasting.

Ageratum (A) Tom Thumb, blue.

Amaranthus (A) Joseph's Coat.

Aster (A) China, mixed.

Aster (A) Comet mixed.

Asparagus (P) ornamental.

Aquilegia (P) Columbine mixed.

Bachelor Button (A) mixed.

Balsams, (A) double extra choice mixed.

Bellis (P) pure white, double daisy.

Calendula (A) Pot Marigold, double mixed.

Cilliopsis, (A) mixed.

Canipanula, (A) Canterbury Bells.

Canna, (A) Crozy's finest mixed.

Candytuft, (A) fine mixed.

Candytuft, (A) white.

Carnation, (A) double mixed.

Carnation, (A) Margaret.

Centaurea, (A) Margaritea, sweet scented.

Centaurea, (A) eyanus cornflower.

Celosia, (A) Cockscomb, dwarf mixed.

Chrysanthemum, (A) double mixed.

Chrysunthemum, (A) single mixed.

Clematis, (A) blue.

Cobea, (A) scandens.

Columbine, (P) double mixed.

Coreopsis, (A) fine mixed.

Cosmos, (A) fine mixed.

Cosmios, (A) early mixed.

Cypress Vine, (A).

Cucumber, Wild, (A).

(Yalifornia Poppy, (A) yellow.

Dahlia, (A) double mixed.

Dianthus, (A) China pink, double mixed.

Feverfew, (A).

Four O'Clock, (A).

Foxglove, (P) mixed..

Geranium, mixed.

G'obe Amaranths, (A) mixed.

Gourds, (A) ornamental.

Giallardia (A).
Heliotrope, (P) mixed.

Hollyhock, (B) Alleghany.

Hollyhock, (P) mixed, double mixed.

Humulus, (A) Japanese Hops..

Ice Plant, (A).

Job's Tears, (A) ornamental.

Larkspur, (P) finest mixed.

Lantana, (A) mixed.

Lathurus, (P) Sweet Peas.

Lobelia, (A) fine mixed.

Linum, (A) scarlet flax.

Marigold, (A) French Dwarf.

Matricara, (A) Unicorn Plant.

Mignonette, (A) large flowered.

Mignonette ,(A) sweet.

Morning Glory, tall.

Morning Glory, dwarf.

Musk Plant, (A).

Myocotis, (P) Blue Forgetr-Me-Not.

Nasturtium, dwarf.

Nasturtium,, (A) tall mixed.

Nicotiana, (A).

Pansy, (P) German mixed.

Pansy, (P) Giant Trimadean mixed.

Petunia, (A) fine mixed.

Phlox, (A) Drummondii, mixed.

Phlox, (A) Star of Quedlinburg, mixed.

Phlox, (P) mixed.

Pink, (A) China.

Poppy, (A) Carnation Flo wor.

Poppy, (A) Shirley.

Pcppy, (A) California, yellıw.

Poppy, (A) Iceland, double.

Portulaca,(A) mixed, double.

Portulaca (A) mixed single..

Salpiglosis, (A) dwarf mixed.

Salvia, Splendens.

Scabiosa, (A) dwarf, mixed.

Smilax.

Snapdragon, (A) dwarf, mixed.

Stocks, (A) Cut and Come Again.

Sunflower, (A) double, globe shaped.

Sweet Peas, (A) mixed.

Sweet William, (P) double mixed.

Sweet William, (P) single, mixed.

Verbena, (A) mixed.

Violet, (P) blue, sweet scented.

Virginia Creeper.

Wall Flower, German, double mixed.

Wild Cucumber Vine.

Zinna, (A) dwarf, mixed.

ALL FLOWER SEEDS ON THIS PAGE, 5c PER PACKAGE.

WE PREPAY POSTAGE ON ALL GARD EN AND FLOWER SEEDS, EXCEPT PEAS, BEANS AND CORN. 


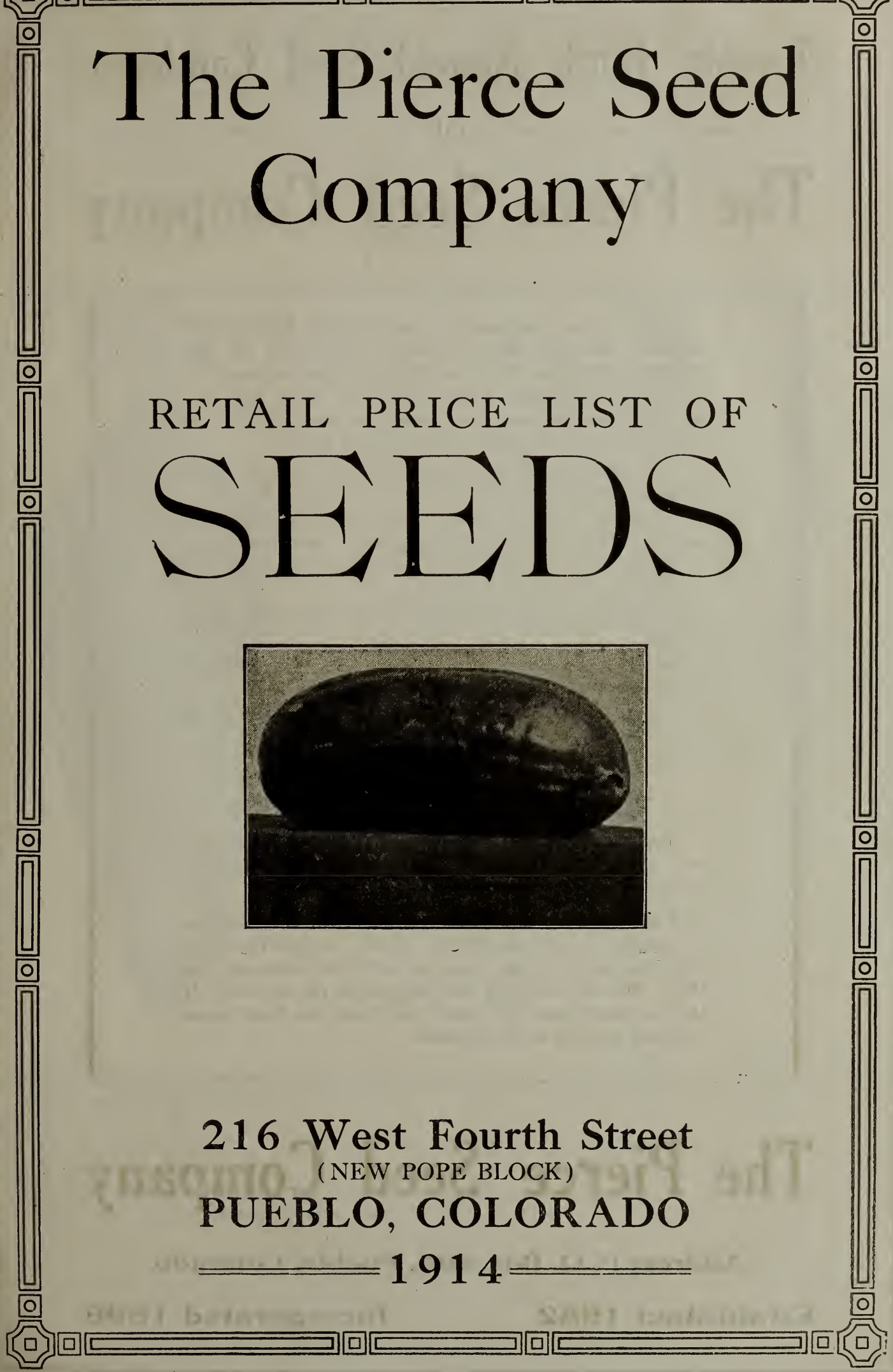




\title{
Twenty Ninth Annual Seed Catalogue
}

OF

\section{The Pierce Seed Company}

When in the city ask for the PIERCE SEED CO.'S STORE. You are always welcome. Owing to the new PARCEL POST LAW, all merchandise rates are regulated by weight and zone. Seeds, bulbs and plants still take the old rate of one - half cent for every ounce, and weight has been increased to Parcel Post weight.

We prepay postage on vegetable or flower seed in ounce, pound or packet orders, except when otherwise stated.

ERRORS. We exercise the utmost care in filling orders, yet in the rush of the busy season errors sometimes occur, in which event we wish to be promptly notified and will try and correct errors satisfactorily.

Money must be sent by Money Order, Registered Letter or Draft.

Of all seeds quoted in the 100-1b. lots, 25 pounds will be furnished at the same rate per pound.

We sell packets of any seeds quoted, at 5c and 10c per packet.?

Prices subject to present stock unsold.

\section{TERMS: CASH WITH ORDER}

NO WARRANTY-A great many ask us if we warrant our seeds. We do unt in any respect. We believe the seeds we offer are unsurpassed in quality.

THE PIERCE SEED CO. gives no wartanty, express or implied, as to description, purity, productiveness or any other matter of any seeds or bulbs they send out, and they will not be in any way responsible for the crop. If the purchaser does not accept the goods on these terms they are at once to be returned.

\author{
Address P. O. Box 495, Pueblo, Colorado
}




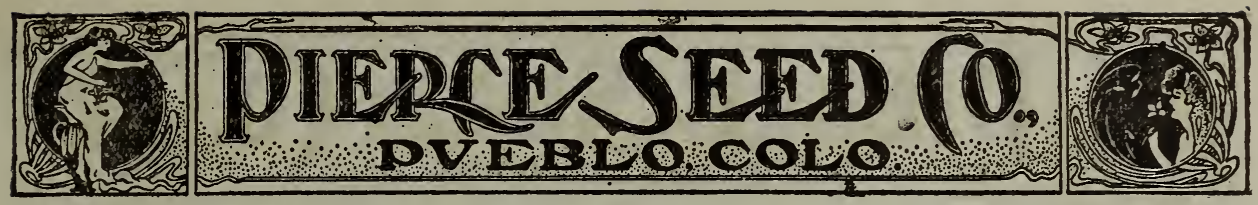

\title{
Sugar Beets and Mangel Wurzel
}

\author{
For Stock Feed
}

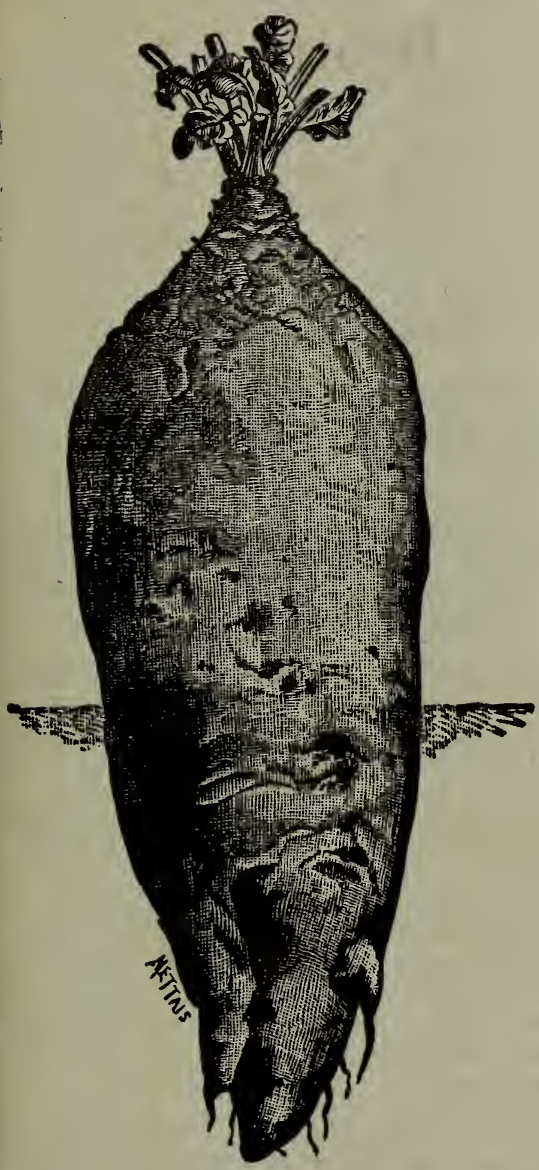

CULTURE-As all Mangels require a deep soil in order to grow well, plow and subsoil from a foot to 18 inches, and apply plenty of rich stable manure. Sow from April 10 to last of May, 4 to 5 pounds to the acre, in rows 18 inches to 2 feet apart, and thin to 18 inches in the rows. As soon as frost occurs, dig the crop. In order to be well preserved for gradual consumption during the winter, Mangel Wurzel should bo heaped to a height of 4 to 6 feet on a dry, sloping situation, and covered lightly with straw, hay or corn stalks and enough soil to keep the covering from blowing off. As soon as this soil becomes frozen, cover all about 8 or 10 inches deep with more soil. By following up this gradual process of covering, all danger of heating will be obviated and the roots will keep ind perfect order.

MANGEL WURZEL, MAMMOTH LONG. RED. One of the largest and best croppers.

GIANT STOCK FEEDING MANGEL WURZEL, OR HALF MANGEL, HALF SUGAR BELT. This variety is grown more each year; is a good yielding stock beet and suitable for all kinds of stock, producing nearly as heavy a yield per.acre as Mangel Wurzel.

MANGEL WURZEL, YELLOW GLOBE. Globe shape, medium size, and by some growers preferred to ather varieties.

MANGEL WURZEL, GOLDEN TANKARD. Valuable yellow fleshed variety, said to contain a large per cent of sugar; very productive; matures early, growing nearly all above the ground; is very easy to harvest.

LANE'S IMPERIAL SUGAR. This variety is considered one of the most desirable for general stock feeding. Good for cattle, hogs and sheep. Has more sugar than the Mangel Wurzel, but not as much as regular sugar beets. Some call this variety half sugar, half mangel.

WHITE FRENCH SUGAR. One of the best sugar beets for stock feeding.

Price-

Ib.

Mammoth Long Red Mangel Wurzel................... 40c

Yellow Globe Mangel wurzel......................... 40c

Golden Tankard Mangel wurzel..................... 40c

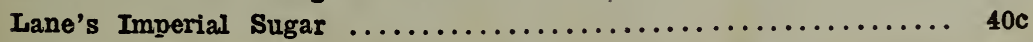

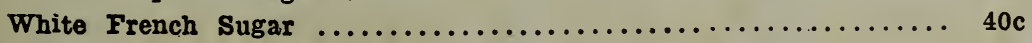

Giant stock Feeding Mangel........................ $40 \mathrm{c}$

We Make Special Prices on Iarge Iots.

$35 \mathrm{c}$

$35 \mathrm{c}$

$35 \mathrm{c}$

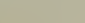

$35 \mathrm{c} \quad 30 \mathrm{c}$

$35 \mathrm{c} \quad 30 \mathrm{~d}$

$35 \mathrm{c} \quad 30 \mathrm{c}$

IT IS NOT UNCOMMON TO RAISE 40 TONS OF MANGEL WURZELS TO THE ACRE ON HIGHLY FERTILIZED LAND. 


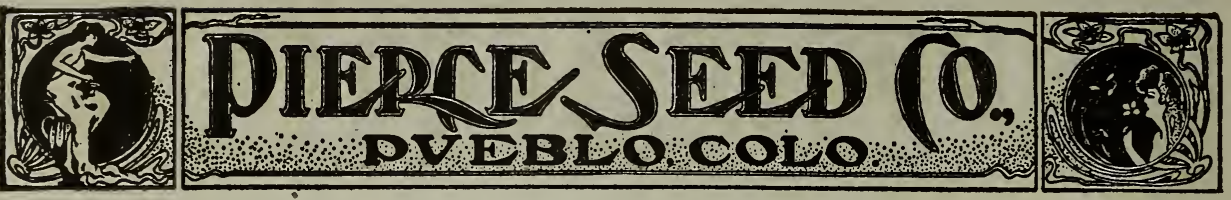

\section{Catalog \\ of

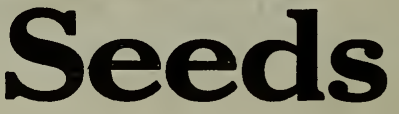

\section{Artichokes}

ARTICHOKES.-Require a deep, rich, sandy loam with plenty of well rotted manure. Sow seed in April or May; when large enough transplant in rows three to four feet apart, two feet in the rows. They reach maturity the second year. Also may be sown in hot bed in February and transplanted in May. In this way crop may be gathered frist season. The heads should be cut off before ripening for culinary purposes.

SELECTED LARGE GREEN GLOBE, PER OZ., 40c.

\section{Asparagus}

Sow in drills one foot aparts and when the plants are four or five inches high they should be thinned out so the plants will be nine inches apart in the rows. Keep the weeds ; down thoroughly the first year, else they choke down the young seejdlings. Thie deeper the soil and greater the abundance of manure that is used, the greater the crop. The experience of Colorado gardeners is

hat Aspa:agus can be cut

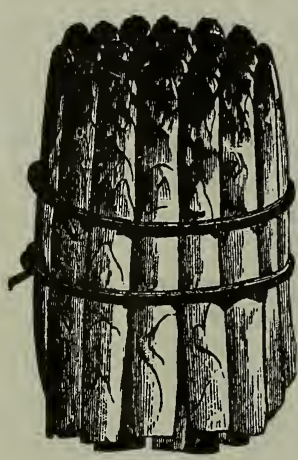

rom one to two years earlier than in the east. It is the most profitable crop grown on the market. $1 \mathrm{oz}$. sead to 6 feet of drill.

FARLY ARGENTEULL.-Earlivr, larger and better than the standard Conover's Colossal. Oz., 10c; 1/4 1b., 25c; 1b., 75c.

OOLUMBIAN WHITE MAMMOTH.-This is a very large white asparagus; it furnishes white shoots which stay white as long as fit for use. Seed produces 80 to 90 per cent of white plants. Oz., 10c; 1/4 1b., 25c; 1b., 75c.

( ONOVER'S COLOSSAL.-A standard variety. Oz., 10c; 1/4 Ib., 15c; lb., 50c.

E CAN SUPPLY ASPARAGUS ROOTS IN SEASON.-Two- year-old roots., per doz., 25c; per 100, by express, 75c; mail, per 100, $\$ 1.25$; special price per 1,000 on application.

\section{Beans}

60 POUNDS TO THE BUSHEL.

Select light, warm soil; plant when danger of frost is past in spring, about two feet apart, in drills; cover one inch deep; $1 \mathrm{lb}$. to 50 feet of drill. 75 to $90 \mathrm{lbs}$. seed to acre. Add 8c per pound for beans if sent by mail.

\section{DWARF OR BUSH.}

HOPKINS' RED VALENTINE.- Green pods; early; nearly whole crop can be picked at one time; desirable for market gardeners. Lb., 15c; 10 lbs., $\$ 1.25$.

BURPEE'S STRLNGLESS. (Green Pod).—Extra early stringless; a very fine bean for market gardeners and home use; pods round and fleshy, free from strings. Lb., 15c; 10 lbs., \$1.25.

GIANT STRINGLESS (Green Pod).-This bean has the same good qualities of Burpee's Sitringless Green Pod, but very much larger. Early and prolifie, Ib., 15c; $10 \mathrm{lbs}$., $\$ 1.25$.

REFUGEE.-Green pods; a very prolific bush sort; pods round; fine flavor; used extensively for canning. Lb., 15c; 100 lbs., \$12.50.

DAVIS' WHITE KIDNEY WAX.-Very productive; early; rustless; its commercial value as a white kidney bean is unsurpassed; in time of over-production as a snap bean let them go to seed and they will sell as a dry bean. Ib., $15 \mathrm{c} ; 10$ lbs., $\$ 1.25$.

PTNCII POD BIACK TAX-A very àsiruble round pod wax bean. Not as prolific as German or Prolific Elack Wax, but very fine flaror. Lb., $15 \mathrm{c}$.

CURRIE'S RUST PROOF.-Yellow pods, flat and long, a very desirable bean for market gardesers. Stand up well when shi! p:d. Ib., 15c; $10 \mathrm{lbs}$., $\$ 1.25$.

TO MARKET GARDENERS: We recommend for first planting of beans. Red Valentine and Stringless for green pod; Prolific Black Wax (round pod), Go'den Wax, and Wardell's Kidney Wax for yellow pod varieties. 


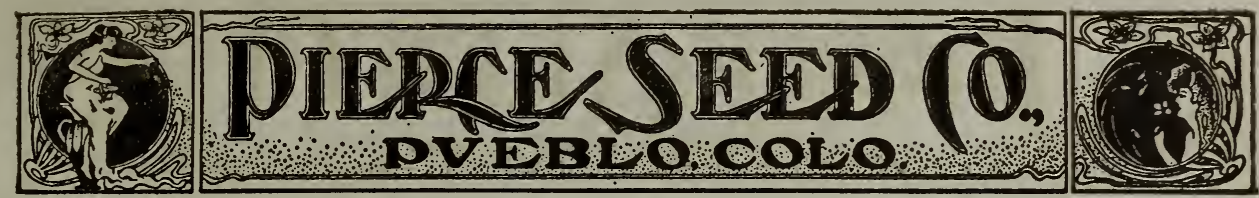

\section{Beans--Continued}

GOLDEN WAX OR BUTTER. - Yellow pods; stringless; early and fine quality; very desirable. Lb., 15c; $10 \mathrm{lbs}$., \$1.25.

BLACK WAX.-Prolific, round, yellow pods; stringless; earliest of wax varieties; superior for bean soup. Lb., 15c; $10 \mathrm{lbs}$., \$1.25.

WARDELL'S KIDNEY WAX.-Yeliow pods; very productive; pods long, broard, flat and of a very delicate yellow; brittle and entirely stringless; beans white and reddish purple at the eye; kidney shape; a very desirable market garder sort. Ib., 15c; 10 lbs. \$1.25.

BROAD WINDISOR.-The largest and best of the class of English dwarf bean; beans are eaten shelled. Ib., 15c.

MEXICAN LIMA.-A large white oval shaped bean, used in green state, same as limas and considered very fine when dry; they require no poles, being a dwarf bush bean. Lb., $15 \mathrm{c}$.

WHITE MARROWFAT.-Extensively grown for winter use; very proiuctive. Lb., $10 \mathrm{c}$.

BURPEE'S IMPROVED DWARF OR BUSH LIMA.-A perfect bush form of true, luscious, large lima bean; bushes grow from 18 to 20 inches high, of stout growth, yet branching vigorously; an immense yielder; the dry beans are larger than Henderson's Bush Lima. Lb., 20c.

NAVY.-Market price.

MEXICAN.-Market price.

Our strain of Mexican bean seed is the very hest. You should change your seed if you are a grower of Mexican beans. Our strain is what you should use. Uniform Pinto. A great yielding variety that sells on sight.

25 to $35 \mathrm{lbs}$. seed to acre.

\section{BEANS.-Pole or Running.}

EXTRA EARLY LIMA.-This new Lima Bean has all the good qualities of the Limas, but is much earlier, which makes it a good acquisition to Colorado. I.b., 20c.

SCARLET RUNNER.-Cultivated for the beauty of its flowers; also for a useful vegetable. Ib., 15c.

LAZY WIFE.-Pods long, dark green color; thick and fleshy, and very productive. Ib., 15c.

BURGER'S STRINGLESS (Pole).-This is a green pod, very much like the Kentucky Wonder or Old Homestead Pole Bean. Some list it as the White Kentucky Wonder. Lb., 20 c.

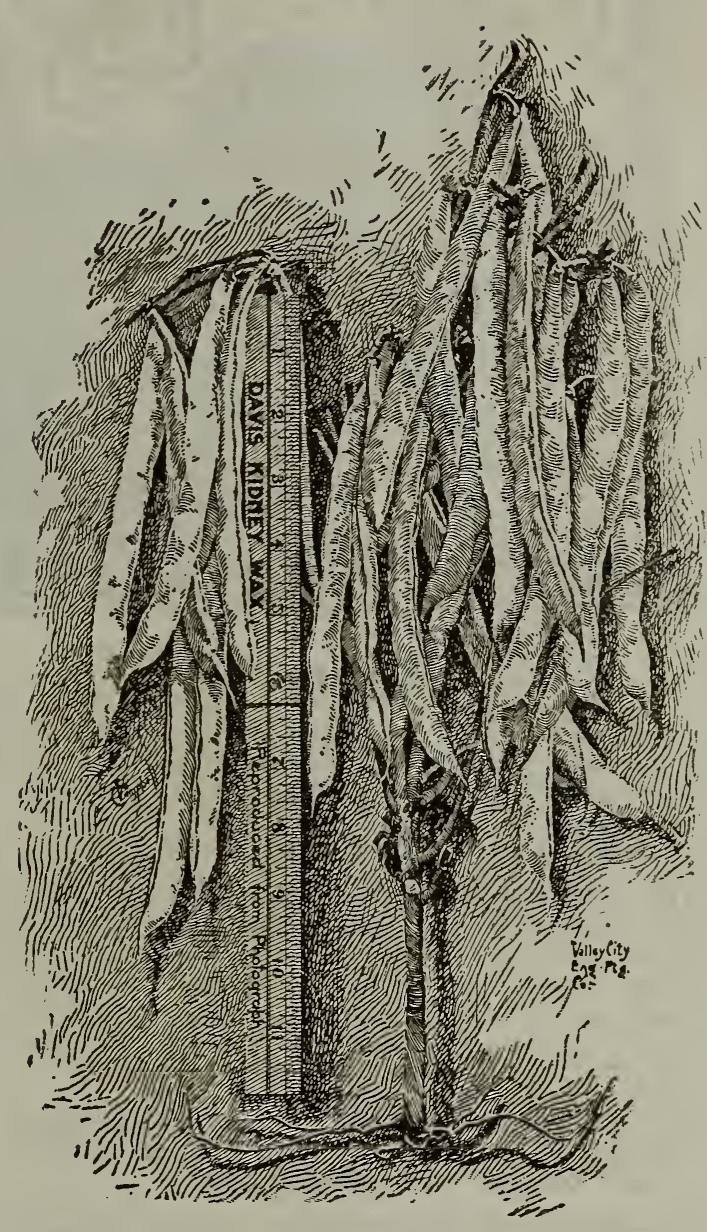

KENTUCKY WONDER OR OLD HOMESTEAD.This most popular variety is an improved.large strain of isouthern Prolific. They are so'id, meaty and strincless when young. and of fine quality. If pods are gathered as they mature the vines will continue to bear to the end of the season. Ib., $15 \mathrm{c}$.

DUTCH CASE KNIFE.-An early variety; large pcids; very productive; good for shell beans. L.b., 1 c.

CRANBERRY POLE OR HORTICULTURAL.-A popular old variety; very productive; to be used either for snap shorts or dry shell beans. Ib., $15 c_{\text {. }}$

Twenty-five pounds of Beans sold at 100-1b. rate. 

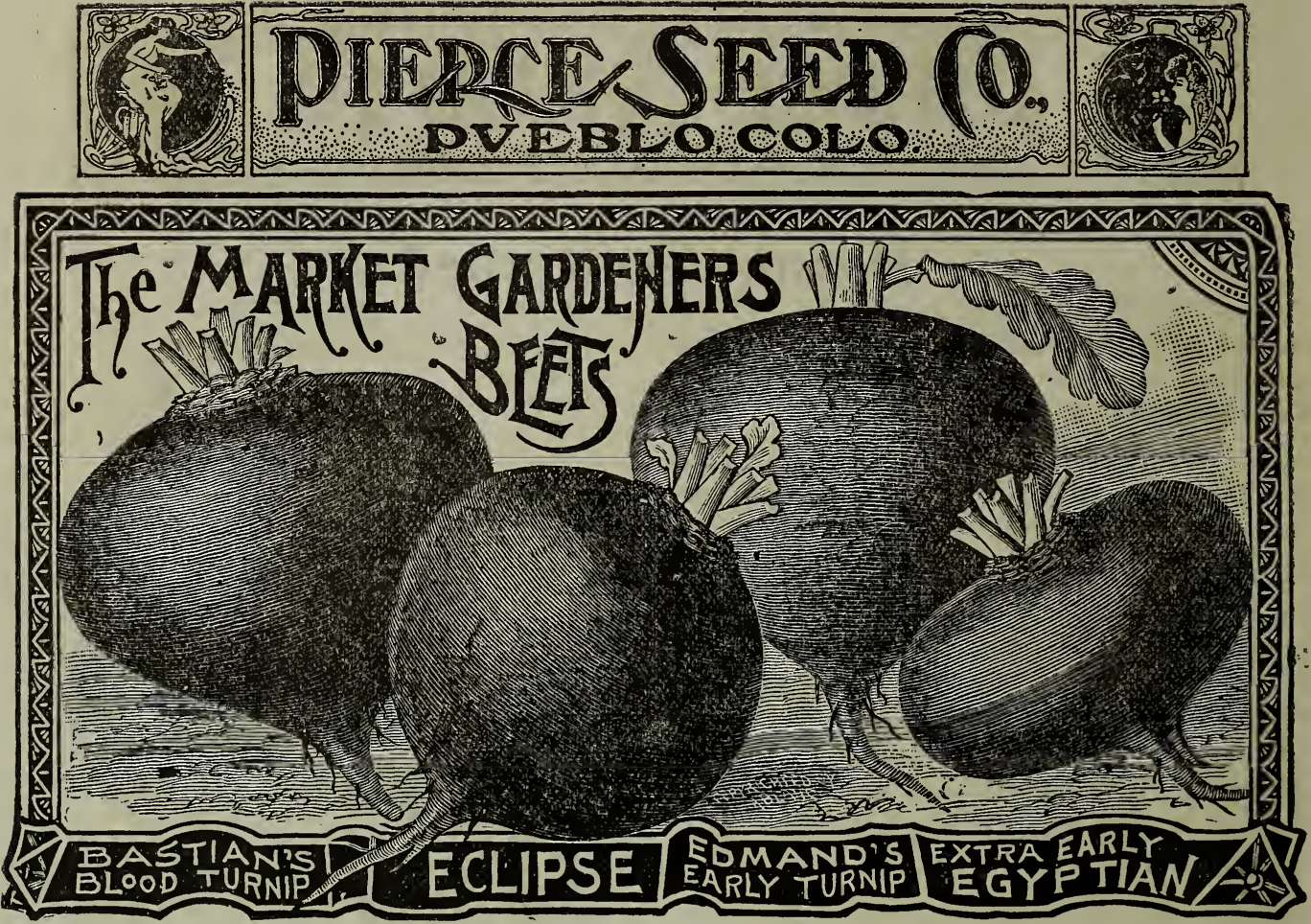

\section{Beets}

Beets require a rich soil. Sow in drills 14 to 16 inches apart, one inch in depth; thin to 4 or 5 inches. For early use, sow as soon as the ground can be worked in the spring.

1 ounce will sow 50 feet of drill.

EDMAND'S BLOOD TURNIP.-A second early and late variety of handsome round shape; the sikin is a very deep blood red; flesh also very dark; exceedingly sweet and tender in quality; they do not grow large, but of a good uniform size; good for butrching. Oz., $10 \mathrm{c} ; 1 / 41 \mathrm{~b} ., 30 \mathrm{c}$; 1b. $75 \mathrm{c}$.

NEW ECLIPSE.-An early variety; globe shape; small top; very sweet; flesh fine dark blood color. Oz., 10c; 1/4 1b., 30c; 1b., 75c.

DETROIT DARK RED TURNIP.-One of the most popular deep red turnip beets for market gardeners and home use. Tops small upright growing, roots globular and smooth, flesh deep bright red. Very crisp and tender. Oz., 10c; $1 / 4 \mathrm{lb}$., 30c; 1b., 75c.

DEWING'S IMPROVED EARLY BLOOD TURNIP.-Very early; grows to larga size. Oz., 10c;, 1b., 75c.

CROSBY'S IMPROVED EGYPTIAN.-A very superior strain of blood-red Egyptian; not so flat as the ordinary Egyptian; forms turnip-shaped beets in its early growth, thereby making it a very desinable early variety for bunching; few small tops, very small tap root; of very fine quality. Oz., 10c; 1/4lb., 30c ; 1b,. 80c.

I,ONG BLOOD.-A long red beet. Oz., 5c; $1 / 4$ lb., $15 \mathrm{c}$; 1b., $50 \mathrm{c}$.
WHITE FRENCH SUGAR-Although a sugar beet, it is extensively grown for stock feed. Ib., 40c; $10 \mathrm{lb}$. lots, 35c per lb.

LANE'S IMPROVED SUGAR.-An improvement on the White French Sugar; hardy; very productive; contains a large per cent of sugar; grown extensively for stock feed. Ib., 40c; 10 ib. $\operatorname{lot}_{\mathrm{S}} 35 \mathrm{c}$ per $\mathrm{lb}$.

For first sowing use Eclipse, Detroit Dark Red and Crosby's Improved Egyptian; they are a good bunching beet.

\section{MANGEI, WURZEI.}

Stock Feeding Varieties.

Special price 100 lbs. or over.

MAMMOTH LONG RED.-One of the largest and best croppers; fine quality. Ib., $40 \mathrm{c}$; 10 Ib. lots, $35 \mathrm{c}$ per $1 \mathrm{~b}$.

YELLOW GLOBE IMANGEL-Large variety; good keeper. Ib.., 40c; $10 \mathrm{lb}$. lots, 35c per $1 \mathrm{~b}$.

GOLDEN TANKARD.-Ib., 40c; $10 \mathrm{lb}$. 10ts, 35c per $1 \mathrm{~b}$.

\section{Broccoli}

Grow plants and cultivate same as cabbage. Plant 2 feet apart each way when plants are about 4 inches high.

EARLY WHTTE.-Per pkt., 5c; 0z., 25c.

\section{Brussels Spouts}

Sow and cultivate same as cabbage, transplant 1 foot apart in rows which should be 10 inches apart.

IMPROVED HALF DWARF.-The very brst and surest strain. Oz., 15c; 1/4 1b., 50c; 1b., \$1.75. 


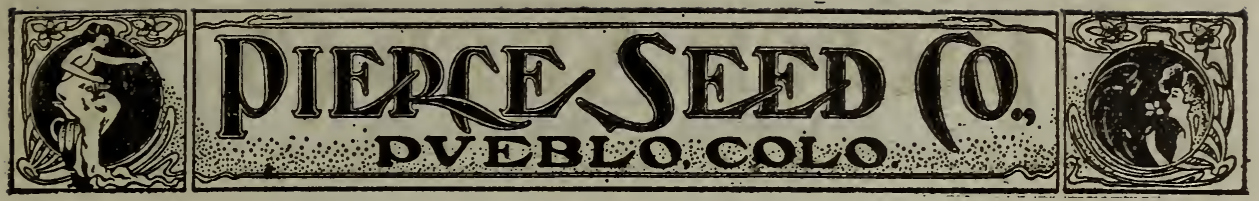

\section{Cabbage}

Cabbage will thrive on any good land. Plow deep and manure freely. The early varieties are sown in hot beds in February; the late sorts in the month of April. Plant in rows about 20 inches apart, 2 feet between the rows. One ounce of seed produces 1,500 to 2,000 plants.

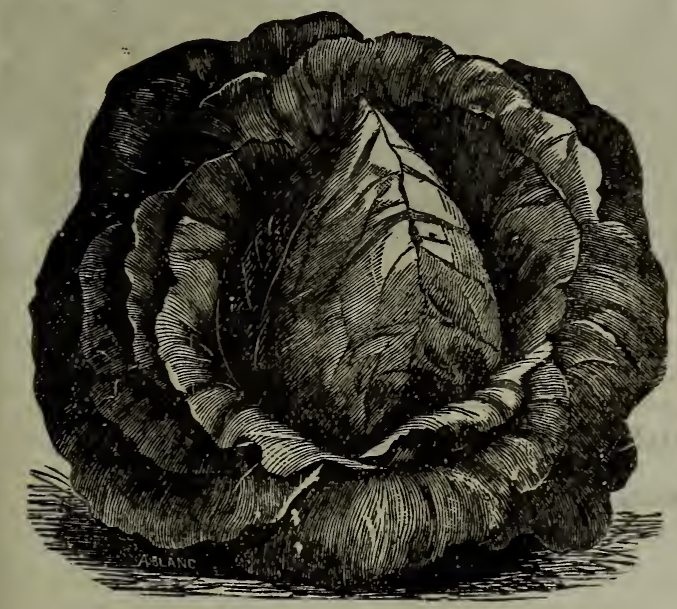

Early Jersey Wakefield.

EARLY JERSEY WAKEFIELD.-(True Seed).The most popular and valuable early variety; sure to head; good size; pyramidal in shape. Oz., 25c; 1/4 lb., 60c; 1b., $\$ 2.00$.

THE OHARLESTON OR LARGE EARLY WAKEFIELD. - The same shape and character as the Early Jersey Wakefield, but larger. Oz., 25c; $1 / 4 \mathrm{lb} ., 60 \mathrm{c} ; 1 \mathrm{~b} ., \$ 2.00$.

EARLY FLAT DUTCH.-A first-class second early; round flat variety. $0 z ., 20 \mathrm{c} ; 1 / 4 \mathrm{lb}, 60 \mathrm{c}$; lb., $\$ 2.00$.

HENDERSON'S EARLY SUMMER.-The earliest large heading cabbage; growth very compact and a desirable sort. Oz., 20c; $1 / 4$ lb., 60c; $1 b$. $\$ 2.00$.

EARLY WINNINGSTADT.-Heads cone shaped and solid. Oz., 15c; 1/4 lb., 50c; 1b., \$1.50.

EARLY OANNON BALL.-The hardest heading of all early varieties. Oz., 20c; $1 / 4$ lb., 60c; lb., $\$ 2.00$.

DIAMOND WINTER.-Heads extra hard and solid; medium size, sure header; a good cabbage for this locality. Oz., 30c; $1 / 4$ lb., $85 \mathrm{c}$; $1 \mathrm{~b} ., \$ 3.00$.

DEEP HEAD.-An excellent eropper and sure to head. Oz., 15c; $1 / 4 \mathrm{lb}$., 50c; lb., $\$ 2.00$.
COPENHAGEN MARKET.-A new extra early, round head cabbage, from Denmark. Short stem, head solid and large and of excellent quality. Matures very early and nearly all ican be harrested at one time. Oz., 60c; 1/4 1b., \$1.75.

SURE HEAD.-All head and always sure to head; late variety. Oz., 15c; 1/4 lb., 60c; 1b., $\$ 2.00$.

ALL SEASON.-A raluable market gardener's variety; heads very hard and solid; round; flat ened on top; nearly as early as Early Summer and much larger; it is cálled All Season because it is as good for autumn or winter'as it is for early. Oz., 15c; $1 / 4$ lb., 50c; lb., $\$ 1.75$.

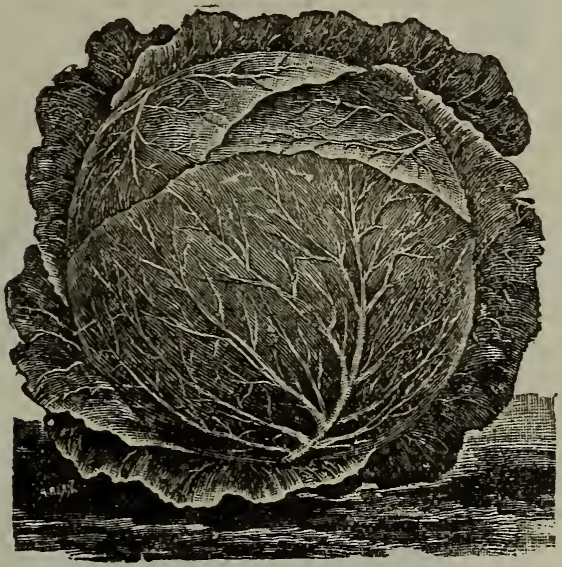

Early Flat Dutch.

EXCELSIOR FLAT DUTCH.-One of the best Flat Dutch; late sort as can be grown; is $a^{\circ}$ good keeper. Oz., 20c; 1/4 lb., 60c; 1b., $\$ 2.00$.

PREMIUM FLAT DUTOH.-A fine strain of Flat Dutch; extensively grown for fall and winter use. Oz., 15c; $1 / 41 \mathrm{lb}, 60 \mathrm{c} ; 1 \mathrm{~b} ., \$ 2.00$.

RED DUTCH PICKLING.-Very valuable for pickling. Oz., 20c; $1 / 4 \mathrm{lb}$., $70 \mathrm{c}$.

Without doubt the best early cabbage now grown is the Jersey Wakefield. Next is the Charleston or Large Early Wakefield, although a week or ten days later than Early Wakefield. Its weight makes it a profitable variety to grow. Grow the flat varieties for sauerkraut. Danish Ball Head or Hollander is one of the best keepers. Can be planted closer than most late varieties, but must be put in earlier than the Fiat Dutch. One fourth pound of seed is enough to grow plants for one acre of ground. 


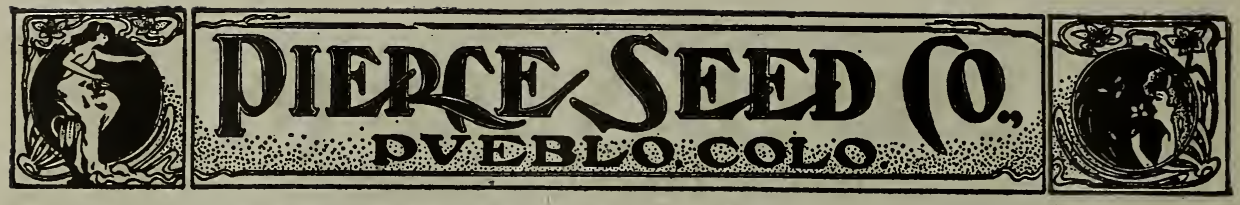

\section{Cabbage}

(Continued).

MARKET GARDENER'S NO. 2.-One of the best second early or summer sorts; grown very extensive y by a few market gardeners near Pueblo and considered a very profitable variety; heads are solid, of medilim size. Oz., 30c; 1/4 1b., \$1.00; lb., $\$ 350$.

DANISH BALL HEAD OR HOLLANDER.A standard late variety, very solid and one of the best keepers. Can be set out closer and must be planted 10 to 20 days earlier than late Flat Dutch, as it takes longer to grow and mature. Oz., 25c; 1/4 1b., 70c; lb., $\$ 2.50$ :

DANISH BALL HEAD.-Short stem. 25 c; $1 / 4$ 1b., 70c; 1b., $\$ 2.50$.

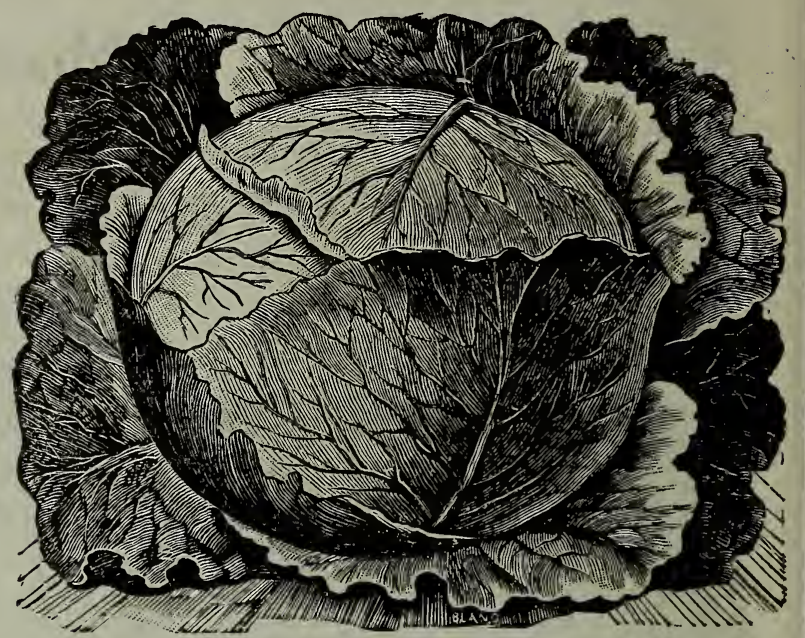

Flat Dutch.

\section{We Import Our Danish Ball Head or Hollander Cabbage Seed. None Better}

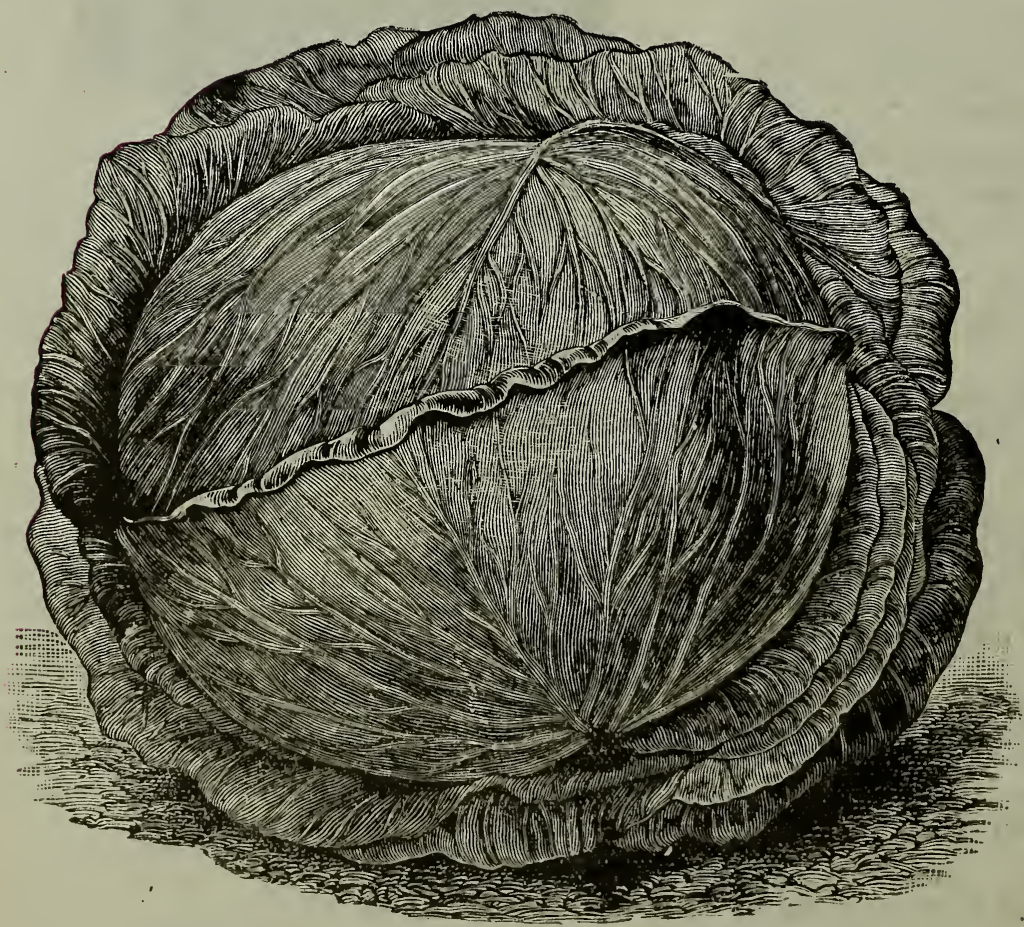

SUCCEISSION. - Whether grown as a second early or main late crop it has no equal; as second early it is a few days later than Early Summer; headis are slightly larger, more perfect and uniform in size; handsome color; of the finest quality; a good keeper. $\mathbf{0 z}$., 25c; $1 / 4$ lb., 70c; lb., $\$ 2.50$. 

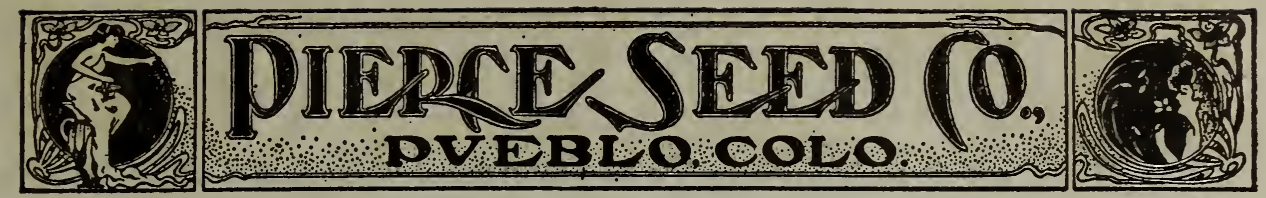

\section{Cabbage}

(Continued.)

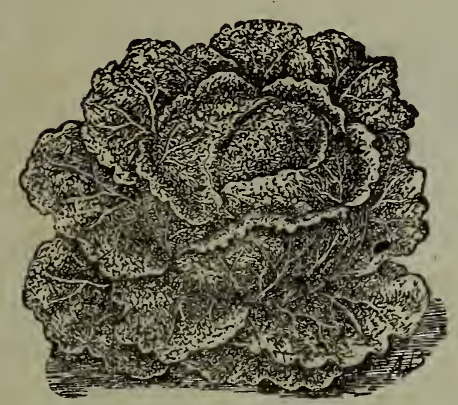

SAVOY NETTED.-This is the finest of the Savoy class; heads large, very solid and compact. Oz., 23c; 1/4 ib., 70c.

\section{Carrots}

Sow in early spring in rows from 10 to 15 inches apart. Carrots require rich, deep, mellow soil. Thin to about four inches apart. Sow $2 \frac{1}{2}$ pounds of seed to the acre.

Carrots a re one of the lest. root crops to feed horses and catt'e, especial'y growing colts.

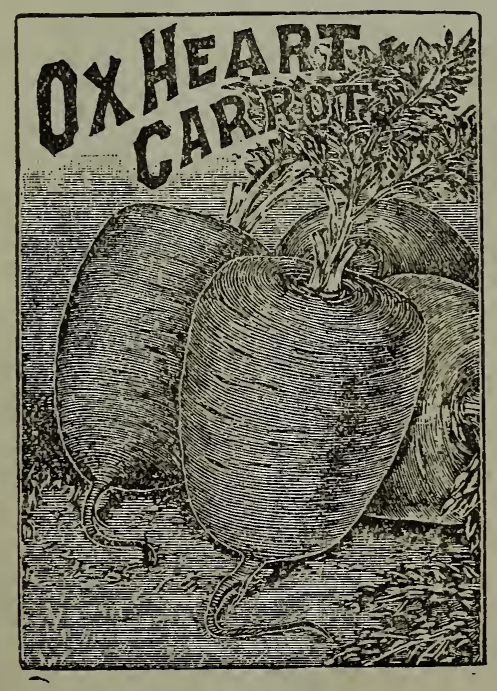

Ox Heart.

GUERANDE OR OX HEART.-A new French carrot; it is intermediate between the half-long and long varieties; of most beautiful shape and color. Oz., 10c; 1/4 1b., 40c; lb., $\$ 1.00$.

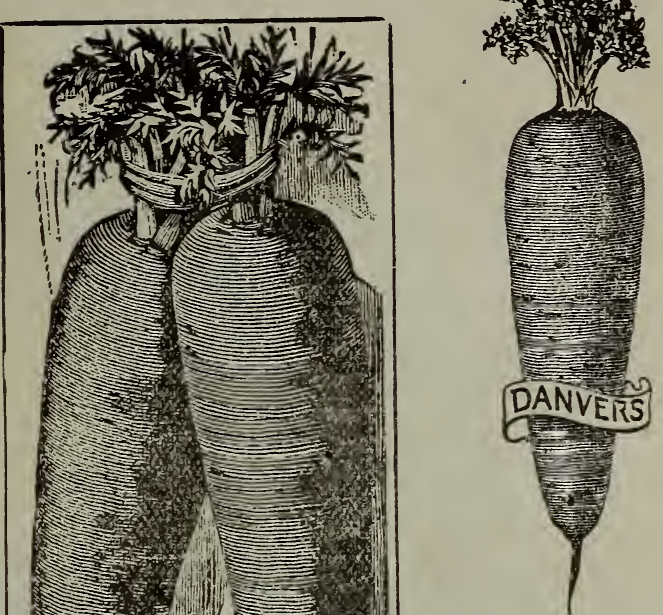

Half Long Danvers.

EARLY H A L' $\mathrm{F}$ LONG DANVERS. One of the most productive and one of the best for sfield culture ; sweet and tender. Oz., 10c; $1 / 4 \quad 1 b_{\text {, }}$ 40 ; lo., $\$ 1.00$.

TMPPOVED LONG ORANGE. - The standard field carrot. $\quad 0 z ., 10 \mathrm{c} ; \quad 1 / 4$ 1b., $40 \mathrm{c} ; 1 \mathrm{~b} ., \$ 1.00$.

EARLY SCARLET HORN.-A fine variety of mediun size; fine flavor. Oz., 10c; 1/4 lb., $40 c$; lb. $\$ 1.00$.

WHITE BELGIAN - When roung the roots are mild and delicate, and when full grown are raluable for stock. Oz., 10c; $1 / 4$ lb., 40c; lb., $\$ 1.00$.

SMALL FRENCH FORCING.-The earliest variety; mostly used by gardeners for forcing. Oz., 10c; 1/4 lb., 40c; 1b., $\$ 1.35$.

\section{Chicory}

I:ARGE ROOTED - The leares are used for salads; and dried roots of this rariety are used as a substitute for coffee. Oz., 10c; 1/4 1b., 25c. 

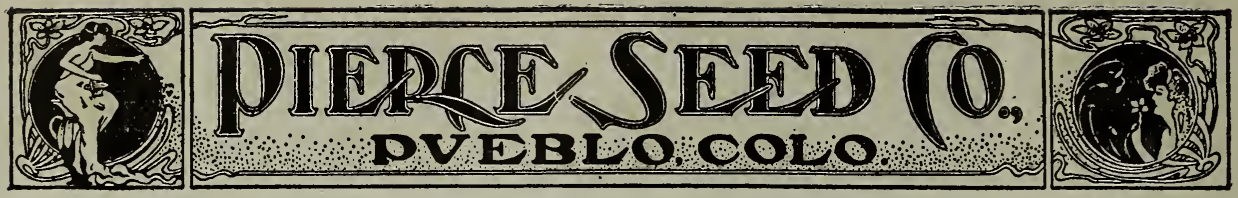

\section{Cauliflower}

One ounce seed produces 1,500 to 2,000 plants

Requires same treatment and culture as Cabbage.

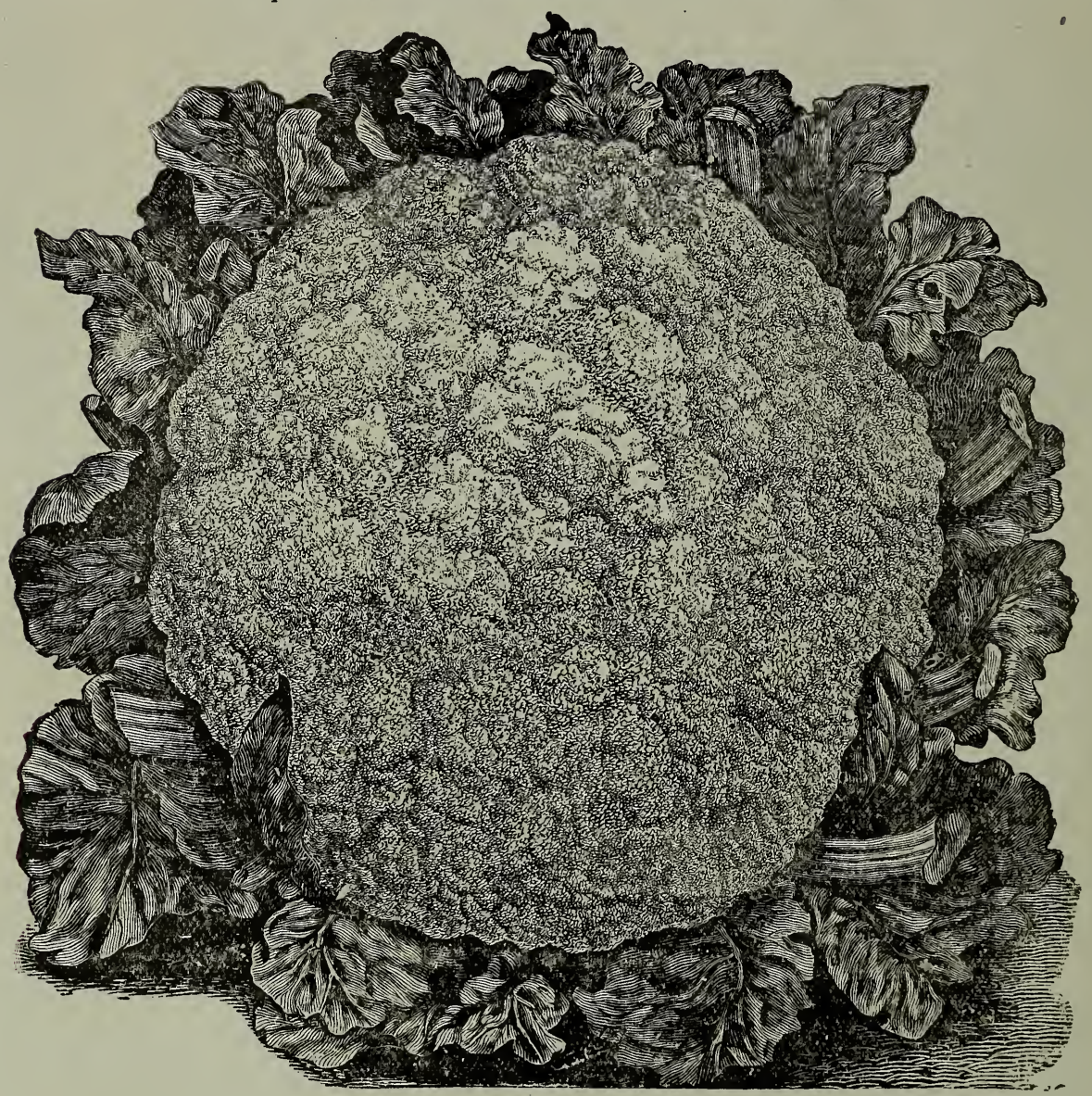

Early Snowball Caulifiower.

EARLY SNOWBALL-The earliest; the surest header; the most profitable; the best variety for either the market or the family garden. Ear'y Snowball Cauliflower is superior to all others for the reason that its growing, compact habit enables one-third more to the planted on the same space of ground than can be done with any other variety. It does equally well for late planting. Price: Package, 25c; 1/4 oz., 60c; oz., $\$ 2.00$.

DANTSH GIANT.-A large late Cauliflower producing compact white head; should be planted rather early in order to produce heads before severe cold weather as the plants grow to a very large size before forming heads. Oz., 60c; $1 / 4 \mathrm{ib}$., $\$ 2.00$.
We import our Early Snowball Cauliflower Seed direct from a Denmark grower, and know that the strain is the very best for this locality. Some of our market gardeners realize over $\$ 500$ per acre from our Snowball variety.

\section{Chervil}

Cultivate and use the curled variety of Chervil like Pars'ey. Sow in early spring in drills one foot apart.

CURLED.-Leaves used for flavoring and garinsh.

ing. Per oz., 10c.

\section{Corn Salad}

EROAD LEAVED.-Oz., 10c; 1/4 1b., 25c.

We Prepay Postage on all Garden and Flower Seeds, Except Peas, Beans and Corn. 


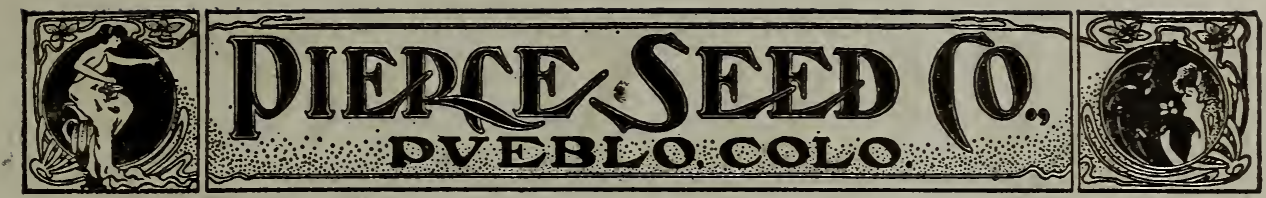

\section{Celery}

Pueblo is a car lot shipper of celery; a greater acreage is being planted each season. The standard varieties are: White Plume, Snow White, Golden Self Blanching, Chicago Giant, all self blanching; Giant Pascal, a winter variety, and should be blanched by trenching.

Sow seed in hot bed; transplant four inches apart when three inches high, in finely pulverized soil; water and protect until well rooted, then transplant into rows 5 or 6 feet apart, either on surface or in well manured trenches a foot in depth; set the plants from six to eight inches apart; to blanch, draw earth around the plants from time to time, taking care not to cover top of center shoots.

One ounce seed produces about 2,000 plants, 4 ounces enough for plants for one acre.

WHITE PLUME CELERY.-The earliest, hand somest and easiest grown, and undoubtedly the earliest celery grown in Colorado. Oz., 25c; 1/4 lb., 75c; 1b., $\$ 2.50$.

CHICAGO GIANT SELF BLANCHING CELERY. In testing this celery it has grown side by side with White Plume, Golden Self Blanching and Snow White, all of which it has excelled in earliness, flavor, qual:ty, height of stock and head, and size of heart. This rariety can be grown in block 8 by 12 inches, or 12 by 12 inches; grown in this way it blanches readi!y without artificial aid. Package, 10c; per oz., 60 s.

NEW SNOW WHITE. - (Livingston's.) - The Snow White is a pure white, self-blanching variety. It is without a rival in purity and color. In vigor of growth, ease of blanching, size, richness of flaror. crispness and purity, it is ideal. It grows solid on all kind's of soil and keeps better than standard varieties. Packet, 10c; oz., $35 c$.

GOLDEN SELF BLANCHING.-Similar to the White Plume in its self-klanching characteristics; very solid and of a rich nutty flavor; plants of a yellowish green colcr; as they mature the inner stems and leaves turn a beautiful yellow. Grown for both early and late use. Oz. $\$ 1.40$ $1 / 4$ lb., $\$ 4.50$; lb., $\$ 17.50$.

Our Golden Self Blanching Celery Seed is French grown. Crop very short.

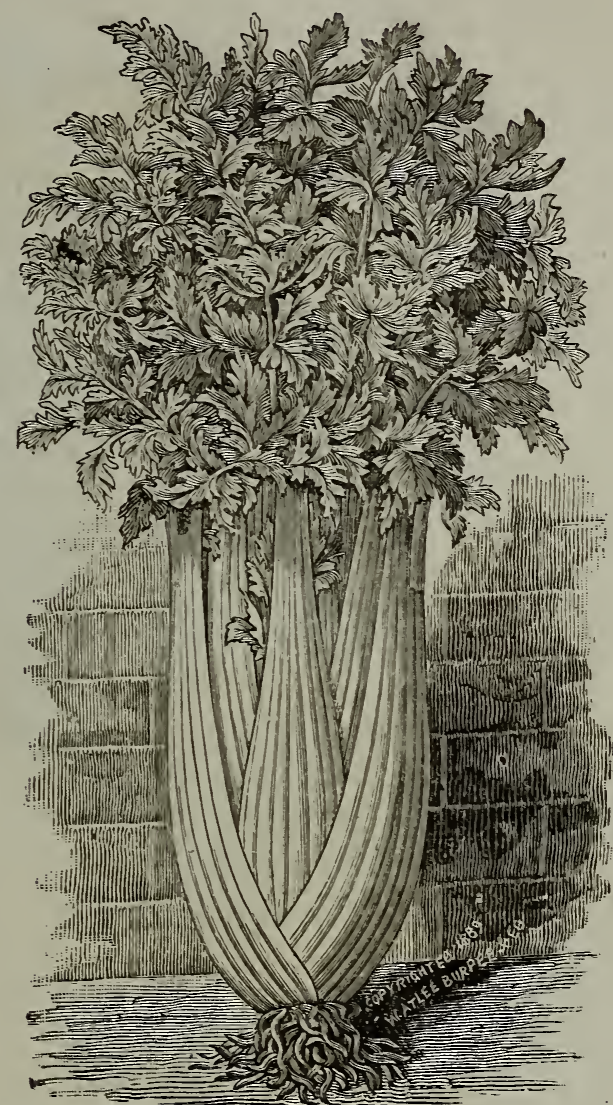

Chicago Giant Self Blanching.

GIANT PASCAL-For a late celery this variety is the very best. Large ribbed, sweet and tender. Superior keeping quality; blanches very easily and quick'y; the heart is golden yellow; the sta'ks are large, thick and solid. Oz., 30c; $1 / 4$ lb., 75c; 1b., $\$ 2.50$.

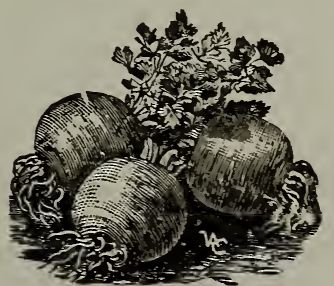

LARGE PRAIGUE (ELERIAC OR TURNIP ROOTED.-The root of which is turnip shaped; is coo'ed o: sliced ard ured with vinegar; more liardy than celery. Oz., 20c.

See Special Prices fo: Plants on Page 31. 


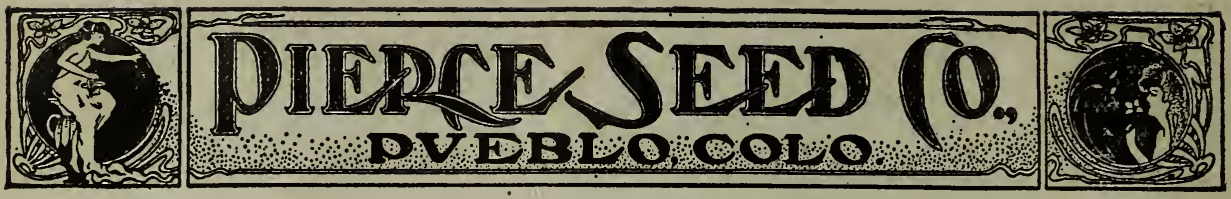

\section{Corn}

Drop in hills three feet apart and leave four plants to the hill. Plant at intervals from early spring to mid-summer.

For a succession, plant Adams, Peep o' Day, Cory, Early Minnesota, Kendel' Early Giant, Black Mexican. Eight pounds to an acre. Add $8 \mathrm{c}$ per lb. if. sent by mail.

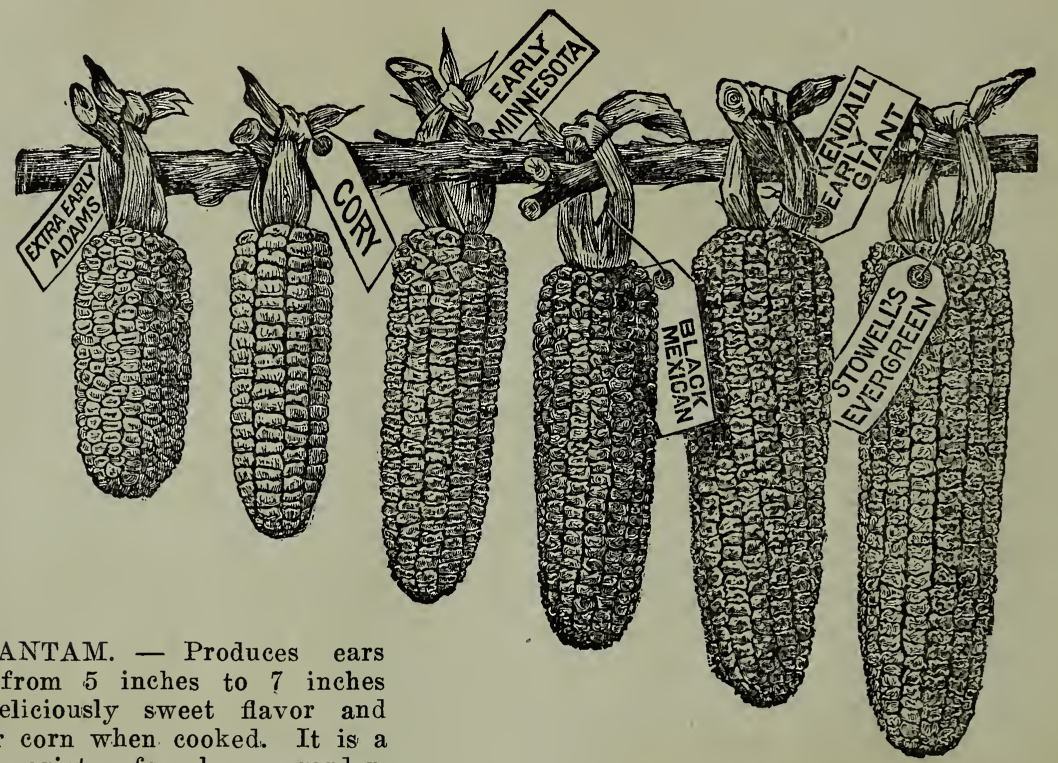
measuring from 5 inches to 7 inches long; a deliciously sweet flavor and very tender corn when cooked. It is a very fine variety for home garden. I.b., $15 c$.

STOWELL'S EVERGREEN.-Hardy and productive; very tender and sugary, remaining a long time in condition for boiling; our strain is the best. Lb., 15c; $10 \mathrm{lb}$. lots, $\$ 1.00$.

Nothing is better than Stowell's Evergreen Sweet Corn, but it is late. Some prefer Country Gentlemen on account of the uneven kernel. The worms do not eat down in the ear so much as in the straight rowed varieties. This is quite an advantage to Colorado corn growers.

COUNTRY GENTLEMEN.-A very sweet corn; medium early; very productive; small cob; kernel shoe peg shape; retains its delicate tenderness and flavor even when a little old. Lb., 1Ec..

EARLY ADAMS.-A very early market variety; ears good size, but short. Inb., 10c.

WHITE COB CORY.-The earliest sweet corn grown; ears of fair size; very sweet; it ma tures for table use in 52 days; try it. Lb., 15c; 10 lbs., $\$ 1.00$.

KENDEL'S EARLY GIANT.-Very early; ears large, kernels pure white; sweet and tender. Lb., 15c; 10 lbs., $\$ 1.00$.

EARLY MINNESOTA.-A very early variety; quick growth; medium size cob. Lb., 15c; 10 lbs., $\$ 1.00$.

PEEP O' DAY.-One of the earliest, very sweet, medium sized ears, and of delicious flavor. Price, per 1b., 15c; $10 \mathrm{lbs}$., $\$ 1.00$.

BLACK MIEXICAN.-Seed black; a very sweet, tender variety, and considered the most sugary of all. Ib., 15c; $10 \mathrm{lbs}$., $\$ 1.00$.

\section{Cress or Pepper Grass}

A well known pungent salad. Requires to be sown thickly and covered lightly at frequent intervals to keep up a succession, as it runs to seed.

EXTRA CURLED.-Very fine; may be cut two or three times. Oz., 10c; $1 / 4$ lb., 20c; 1b., 60c.

\section{Cress--Water}

This is a well known hardy, perennial aquatic plant, grown along the margin of running streams, ditches and ponds. Sow along water edge, and when once started will increase by spreading of rocts and seeding. It has a pleasant pungent taste. Used mostly for greens.. Oz., 50c. 


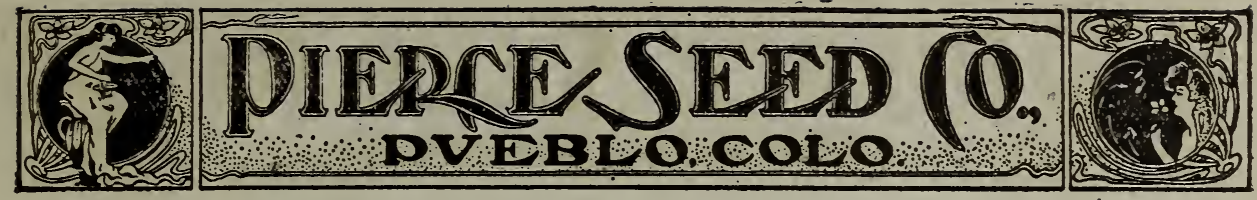

\section{Cucumbers}

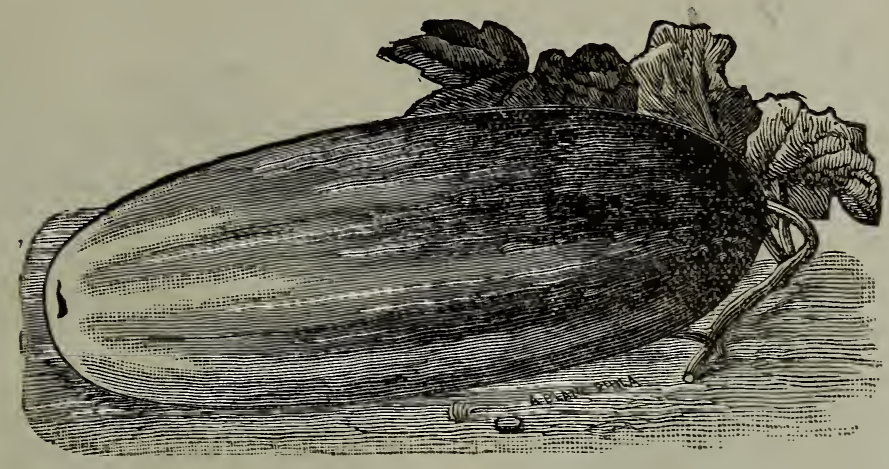

Drop in hills 4 to 6 feet apart, as soon as the weather becomes settled and warm; scatter 8 or 10 seeds to the hill; cover half an inch deep; pat down with a hoe.

One ounce of seed will plant about 50 hills.

EARLY RUSSIAN.-Earliest of all rarieties; grows about 4 inches long. Oz., 10c; $1 / 4$ lb., 25c; 1b., $75 c$.

EARLY FRAME.-Early sort of medium size; straight and handsome. Oz., 10c; 1/4 lb., 30c; 1b., $\$ 1.00$.

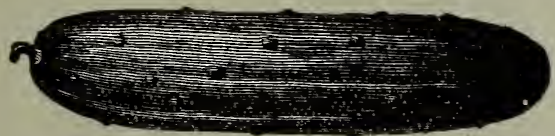

DAVIS' PERFEOT.-A new variety, large even fruit of fine form, dark rich green skin, very few seeds, and solid white flesh. A good bearer. Oz., 10c; 1/4 lb., 30c; lb., $\$ 1.00$.

ARLINGTON WHTTE SPINE.-For market use this variety is much superior to the old White Spine. Oz., 10c; 1/4 lb., 30c; 1b., \$1.00.

LONG GREEN.-Old standard variety; firm and crisp; for general family use there is no better. Oz., 10c; 1/4 lb., 30c; lb., $\$ 1.00$.

GREEN PROLIFIC.-(Pickling).-As a pickling variety is unsurpassed; its characteristics are uniform growth, hardy, ever producing cucumbers not too large for pickling; very productive. Oz., 10c; 1/4 1b.. 30c; 1b., \$1.00.

NICHOLS, MEDIUM GREEN.-(Pickling).-Is exceedingly productive and of medium size; also straight and smooth; one of the best for pickles. Oz., 10c; 1/4 1b., 30c; lb., \$1.00.

FORDHOOK FAMOUS.-One of the largest and most fleshy and fine flavored white spine type. Oz., 10c; !/4 lb., 30c; lb., $\$ 1.00$.
NEW EARLY FORTUNE.-This is a new early cucumber, good size. Actually proven by many expert growers to be the earliest and best Dark Green White Spine cucumber on earth. Wonderfully productive, a model in shape. Price: Oz., 1Ec; $1 / 4$ lb., 35c; Ib., $\$ 1.00$.

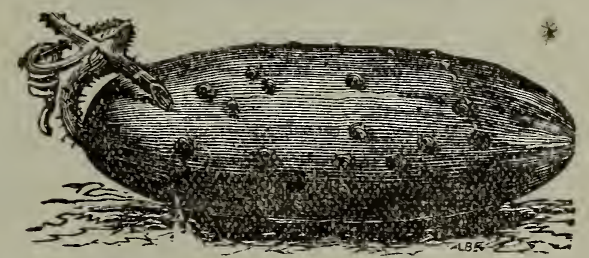

JAPANESE CLIMIING CUCUMBERS.-This new cucumber is a strong and vigorous grower; the young plants are bushy; when established may be grown on fence or trellis, thus saving space in small gardens; the fruit is from 10 to 12 inches long, of a fine green color; solid; fine for pickling as well as slicing. Packet, 5c; oz., $15 c$.

BOSTON PICKLING.-(Pickling).-A very productive kind of superior quality; largely grown by market gardeners about Boston. Oz., 10c; $1 / 4$ lb., 30c; lb., $\$ 1.00$.

CHICAGO PICKLING.-(Pickling).-This is a variety that is taking well among the gardeners who have grown them for pickling cucumbers; very prolific, and for small pickles one of the best. Oz., 10c; 1/4 lb., 30c; 1b., $\$ 1.00$.

Long Green, Improved White Spine and Arlington White Spine are the leading varieties of cucumbers for table use.

\section{Dandelion}

DANDELION.-Improved or thick large leaved. Used for greens and salads. Oz., 40c.

We Prepay Postage on All Garden and Flower Seeds Except Where Noted Otherwise. 


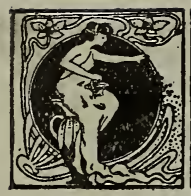

Egg Plant

Sow in hot bedis very early in spring and transplant to two or three feet apart in rich, warm soil.

One ounce seed produces about 1,000 plants.

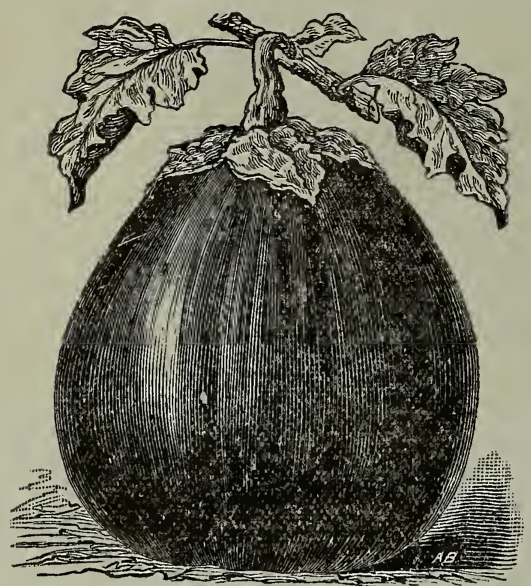

NEW YORK IMIPROVED SPINELESS.-Large purple fruited, spineless strain; productive. $1 / 4$ oz., 10c; 1/2 oz., 20c; 0z., 40c.

NEW YORK IMPROVED PURPLE.-The best variety in cultivation; early; a sure cropper and of fine quality. $1 / 4$ oz., 10c; $1 / 2$ oz., 20c; $0 z$. , 40 s.

BLACK BEAUTY.-Fruit jet black; round and very solid, quite early, and a very fine variety. $1 / 4$ oz., 10c; 1/2 oz., 20c; 0z., $40 \mathrm{c}$.

\section{Endive}

One ounce seed for 150 feet of drill.

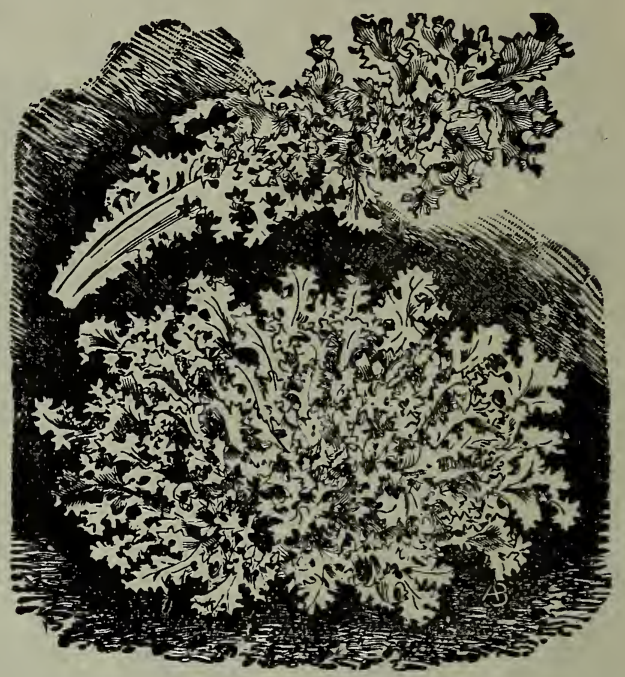

GREEN CURLED.-Not only useful as a salad, but is highly ornamental from its delicate cut and colored leaves; it is much used for garnishing. Oz., 15c; 1/4 1b., 40c; 1b., \$1.25.

BROAD LEAVED BATAVIAN.-Chiefly used in soups and stews; required to be tied up for blanching. Oz., $15 \mathrm{c} ; 1 / 4 \mathrm{lb} ., 40 \mathrm{c}$; $\$ 1.25$.

\section{Kohl Rabi}

A vegetable intermediate between the cabbage and the turnip. Cultivate same as cabbage.

One ounce of seed will make about 2,000 plants. EARLY WHITE VIENNA.-Is a greenish white outside; flesh white and tender while young; the best condition for use is when the bulbs are three or four inches in diameter. Oz., 20c; $1 / 4$ lb., $75 \mathrm{c}$.

\section{Kale}

Sow and cultivate same as cabbage.

DWARF GREEN.-A popular variety; very hardy; improved by frost. Oz., 15c; $1 / 4$ 1b., 50c.

\section{Leek}

LARGE ROUEN.-A large and excellent variety. Price: Oz., 15c; 1/4 lb., 50c; 1b., \$1.75.

AMERIOAN FLAG.-A favorite market variety. Price: Oz., 15c; $1 / 4$ lb., 50c; 1b., $\$ 1.75$.

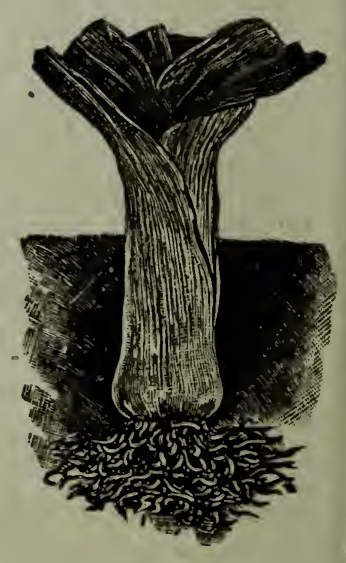

Leek. 


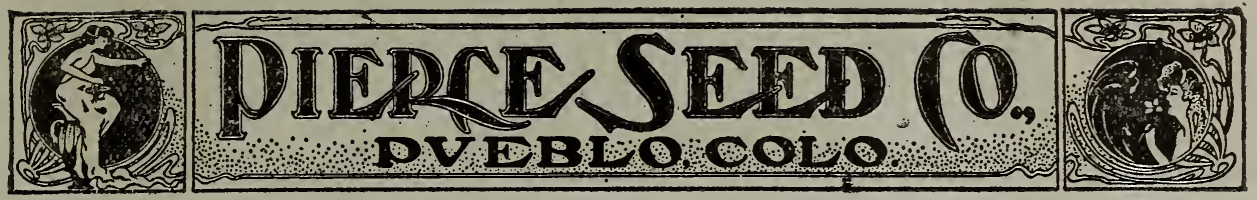

\section{Lettuce}

Sow in rows about 12 inches apart, thin to 8 or 10 inches if you wish it to head. The more rapid the growth, the better the quality.

One ounce seed for 100 square feet or 120 feet of drill.

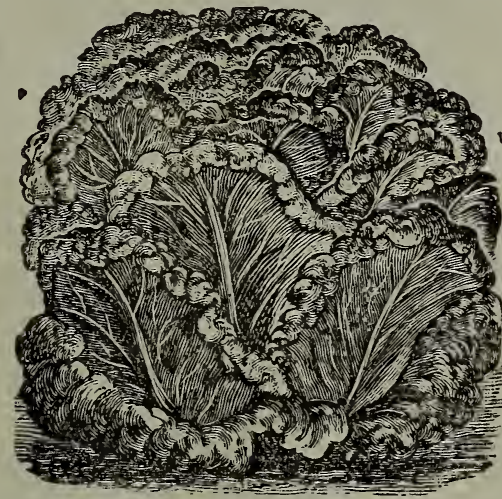

GRAND RAPIDS.-This is the best forcing variety, originating near Grand Rapids, Mich., and it has proved in this vicinity the very best ever grown under glass; it is handsome in appearance; a very strong grower, not as liable to rot as the Elack Seeded Simpson; it will keep from wilting after cutting longer than any other variety, thus making it a good shipper. Oz., 10c; 1/4 1b., 30c: 1b., $\$ 1.00$.

SALAMANDER - A fine compact heading lettuce. The cup shaped leaves are used for serving salads and garnishing. Oz., 15c; 1/4 1b., 35c; 1b., $\$ 1.25$.

EARLY TENNIS BALL.-(Black Seed).-A medium sized head lettuce, very solid and crisp; the inner leaves are rich; creamy white. $\mathbf{O z}$. 10 c; $1 / 4$ 1b., 30c; 1b., $\$ 1.00$.

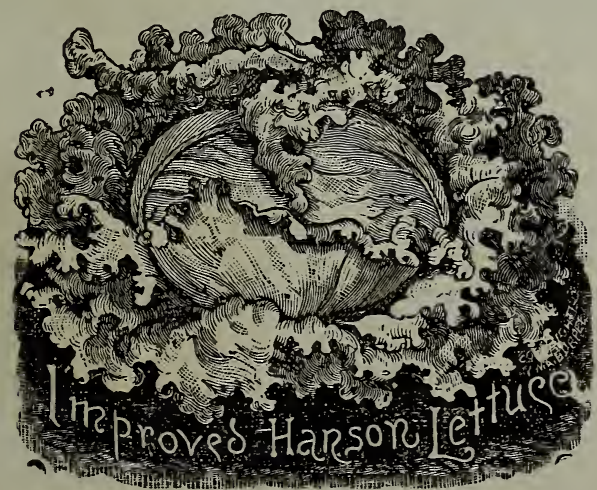

HANSON.-Heads very large, solid, tender and crisp, and of fine flavor; free from bitter taste; light green, almost white. Oz., 10c; 1/4 1b., 30c; lb., $\$ 1.00$.

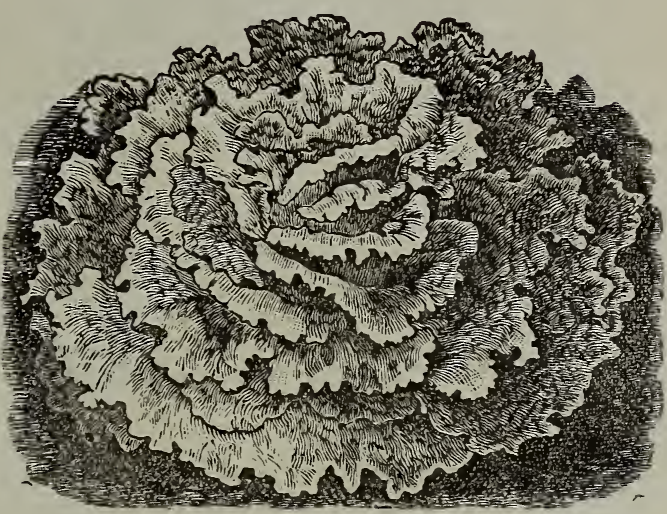

BLACK SEEDED SIMPSON.-One of the very best that is grown; used extensively for foreing uncer glass; a light green, a standard among the market gardeners. Oz., 10c; 1/4 1b., 25c; Ib., $85 c$.

BIG BOSTON.-One of the best heading lettuce for general crop; fine quality and flavor, good shipper. Oz., 15c; $1 / 4$ 1b., 35c; 1b., \$1.25.

PRIZE HEAD -A fine rariety; forms mammoth heads; very hardy, good for home use; the color is rich brown; very tender. Oz., 10c; 1/4 lb., 30c; lb., $\$ 1.00$.

WONDERFUL - A very prolific head lettuce. Heads of immense size and closely folded inner leaves, well blanched. outer leaves a deep, rich green. Oz., 10c; 1/4 Ib., 30c; lb., \$1.00.

Cicis Lettuce.

PARIS COS.-(Self Closing). -The Cos lettuces are quite distinct, anc are popular on account of their tender crisp leaves and delicious flavor. The leaves are long and narrow, and need to be tied up to bleach white. Oz., $10 \mathrm{c} ; 1 / 4 \mathrm{lb} ., 30 \mathrm{c}$.

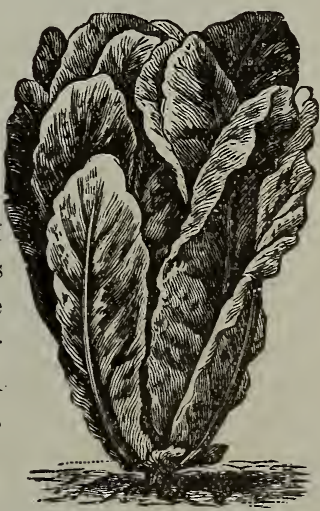

DENVER MARKET.-An early variety of hear lettuce, used extensively for forcing, but does equally well in open ground; it forms large solid heads of light green color, very crisp and tender; is slow to go to seed; a distinct Colo rado variety. $\mathrm{Oz}, 10 \mathrm{c} ; 1 / 4 \mathrm{lb} ., 30 \mathrm{c} ; 1 \mathrm{~b} ., \$ 1.00$. 


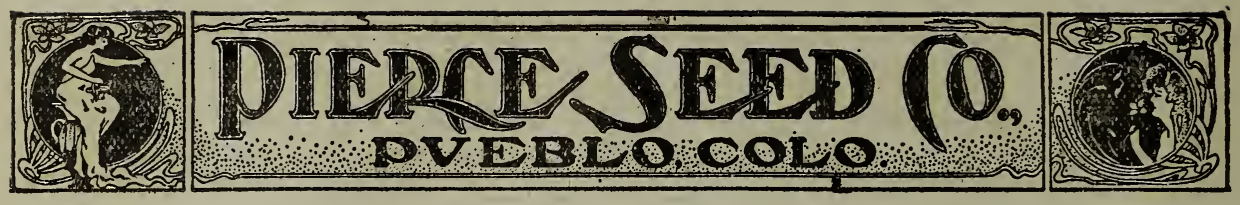

\section{Musk Melons}

Want warm, light soil. Drop a dozen seeds in hills 5 or 6 feet apart. Thin to three or four plants to a hill, when out of danger from insects.

NETTED GEM.-One of the earliest, best and most prolific small melons grown; they are globe shaped, uniform in size; the flesh is light green and of a very fine flavor. Oz., 10c; $1 / 4$ lb., 20c; 1b., 60c.

One ounce seed to 60 hills.

RYAN'S EARLY WATTERS.This strain has had years of select breeding by Ryan Bros., and has made the best records for money returns. The cantaloupes are uniform in size for standard crates, well netted, green fleshed, sweet and spicy. For early market it is unsurpassed. Oz., 20c; 1/4 lb., 40c; lb., $\$ 1.50$.

BLINN'S RUST RESISTANT POLLOCK.-This strain was developed by The Colorado Experimental Station with six years' select breeding. As its name suggests, it is a rust resisting cantaloupe, and ideal seed cavity, in size is a standard, uniform, and prolific, green fleshed shaded to salmon at the center and has that delicious spicy flavor. Oz., 20 c; $1 / 4$ lb., $40 \mathrm{c}$; lb., $\$ 1.50$.

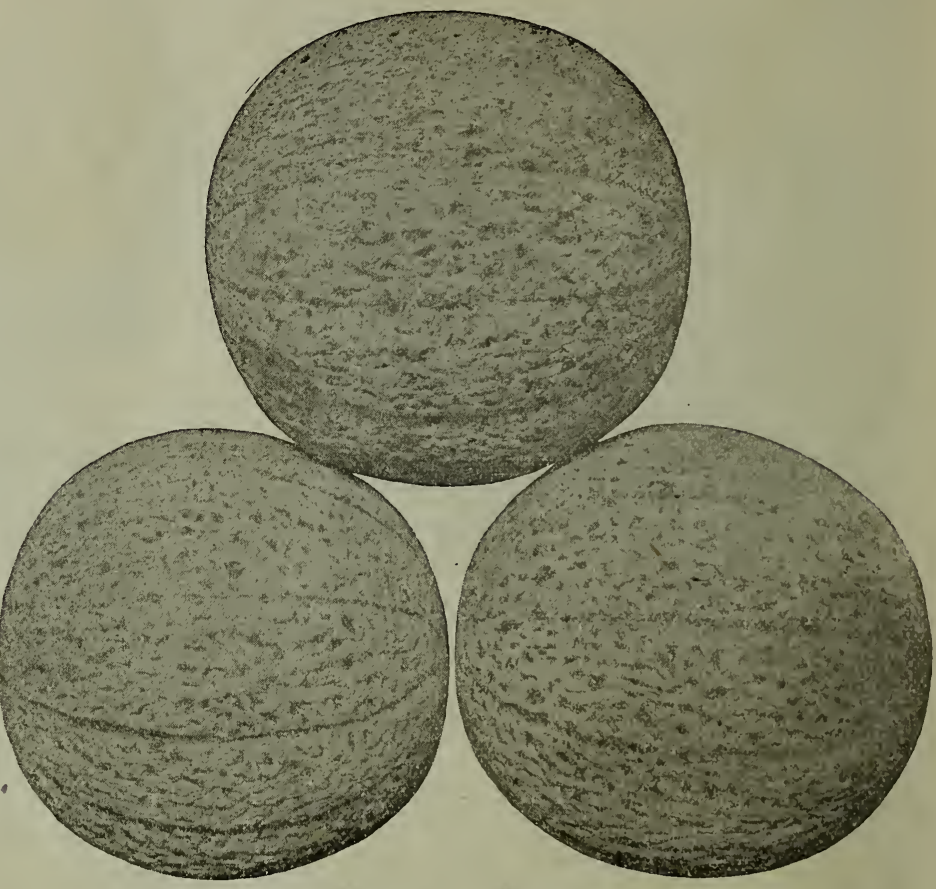

BURRELL'S GEM.-It is an oblong melon, average weight, $2 \frac{1}{2} \mathrm{lbs}$., thin rind; the flesh is a rich salmon color, fine grained and spicy; good bearer; although a thin rind it is an ideal shipper. Oz., 10c; 1/4 lb., 30c; lb., $\$ 1.00$.

PAUL ROSE.-Handsome, oval variety; rich orange flesh, very sweet and a good shipper. Oz., 10c; 1/4 Ib., 30c; Ib., $\$ 1.00$.

MONTREAL.-Round, densely netted, green skin; leads in size all nutmegs. Oz., 10c; $1 / 4$ Ib., 30c; 11 ., $\$ 1.00$.

Our seed of the Ryan's Early Watters, and The Blinn Rust Resistant Pollock is furnished by the Rocky Ford Cantaloupe Seed Breeders' Association. Sold only when accompanied by their certificate, under the hand and seal of the Association.

\section{Rocky Ford Cantaloupe}

Nutmeg shape; green flesh. This variety of cantaloupe is better advertised than any other melon grown, and more growers are fooled with poor seed of this one variety than any other. The seed of the Rocky Ford Cantaloupe that we offer is saved from the most perfect shaped, correct netting, small seed cavity, and choice quality. Oz., 10c; 1/4 Ib., 30c; 1b., \$1.00. Postpaid.

GREEN CITRON.-Medium size; netted; flesh green; rery thi.ck. Oz., 10c; $1 / 4$ Ib., 20c; lb., 60c.

BAY VIEW.-A large, prolific, and fine flavored green fleshed melon. Oz., 10c; $1 / 4$ lb., 20c; lb., $60 \mathrm{c}$.

BANANA.-A long, slender variety, with salmon colored flesh. Oz., 20c; 1/4 lb., $40 \mathrm{c}$.

KHIVA OR WINTER MUSK MELON.-A delicious sweet musk me'on: flesh white and thick; is oblong; skin firm, grayish green color, slightly mottled; they will keep until January and are best in November. Package: 10c; oz., 25c. 

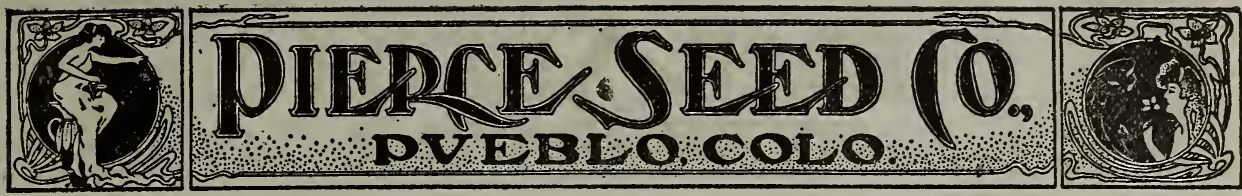

\section{Muskmelons-Continued}

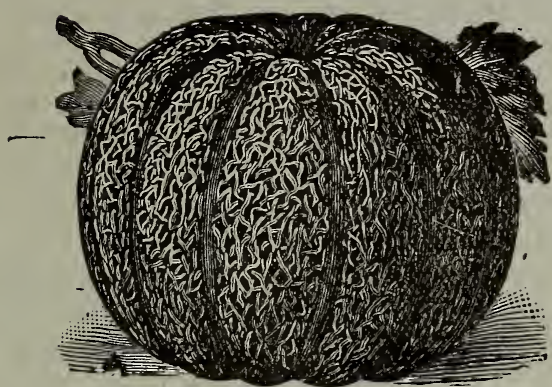

Washington Markçt.

WASHINGTON MARKET-A fine nutmeg melon, well netted; of fair size; uniform growth; one of the very best selling melons grown in this vicinity; secord early. Oz., 10c; 1/4 lb., 30c; Ib., $\$ 1.00$.

\section{Water Melons}

Plant same as Musk Melons; cover one inch deep.

One ounce seed plants 20 to 30 hills.

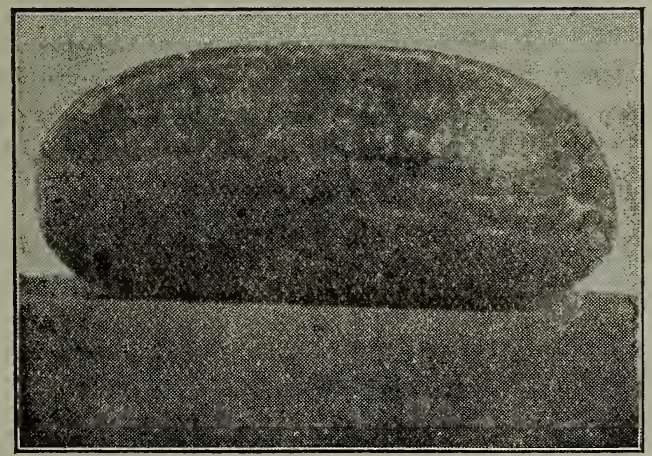

Kleckley's Sweet.

KLECKLEY'S SWEET WATERMELON.-This is without doubt one of the very best melons of récent introduction. Shaped very much like the Rocky Ford, but a larger melon; the skin is a very dark green; flesh bright red; rind ver! thin and hard, making it a good shipper. $\dot{A}$ fine orained melon and solid to the core. Oz., 10c; 1/4 lb., 30c; lb., $\$ 1.00$.

GEORGIA RATTLESNAKE.-A long, large, light green striped, thin rind; flesh deep scarlet; solid. Oz., 10c; 1/4 lb., 25c; 1b., 75c.
ROCKY FORD WATERMELON.-One of the very best me'ons for home and near-by markets. When known it is taken in preference to all others. It is an oblong melon of good size, green skin, bright red flesh and white seeds. We have the very best seed of this variety. Price: Oz., $10 \mathrm{c} ; 1 / 41 \mathrm{lb}, 30 \mathrm{c} ; 1 \mathrm{~b} ., \$ 1.00$; postpaid.

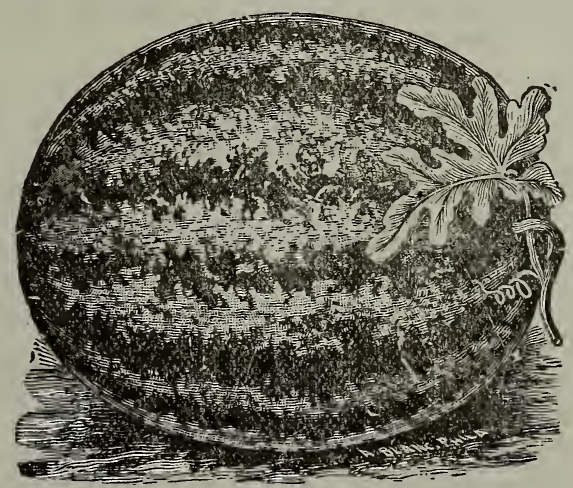

Kolb's Gem.

KOLB'S GEM.-A large oval shaped melon. Kolb's Gem has proven to be the best melon for shipping; has been shipped hundreds of miles without any packing whatever. Oz., 10c; $1 / 4$ lb., 25c; 1b., 75c. 


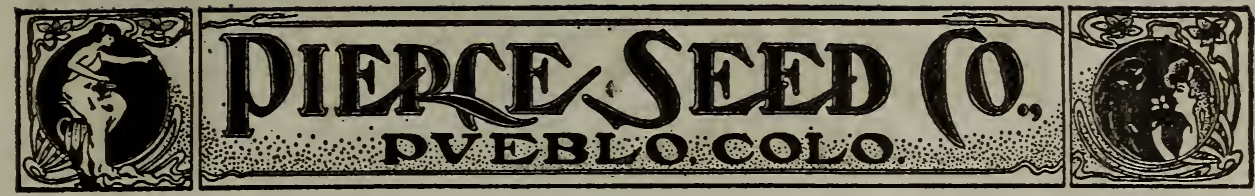

\section{Onions}

Onions thrive best in rather deep, rich loamy soil, and succeed well when cultivated on the same ground for successive years. Plow not over five inches deep and work well with the cultivator; see that the ground is well pulverized; sow the seed in drills about 14 inches apart; keep the surface of the ground open and free from wecus by frequent hoeing; do not stir the soil too deep, or collect it around the growing bulbs.

Sow 3 to 5 pounds to acre in drills.

Special prices on Yellow Danvers, Yellow Globe Danvers and Prize Takers, in 5 and 10 pound lots.

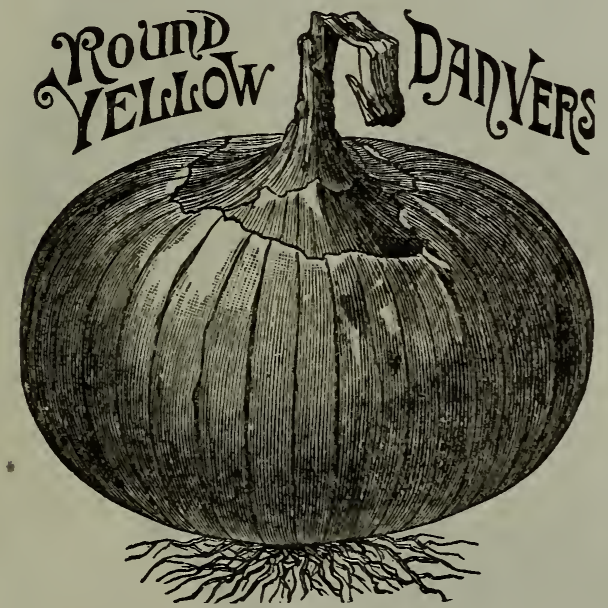

YELLOW GLOBE DANVERS.-This variety is without doubt the rery best onion to grow for a main crop; they are good keepers, always salable, and have proven far more profitable than any other variety in this section. It is a globe shape, and for that reason it is far more productive than the flat rarieties. Oz., 25c; 1/4 Ib., 50c; 1b., $\$ 1.35$.

YELLOW DANVERS.-Round; a good keeper; earlier than the Yellow Globe Danvers, making it a better variety for the foothills; very productire. Oz., 20c; 1/4 lb., 60c; 1b., $\$ 1.35$.

BERMUDA.-White; genuine Teneriffe seed. Oz., 20c; 1/4 Ib., 60c; ib., \$2.00.

EXTRA EARLY RED.-Matures very early; medium size; deep red in color, and an excellent keeper. Oz., 10c; 1/4 1b., 60c; lb., $\$ 2.00$.

EARLY RED GLOBE.-A hand'some, red, globular shape onion, and a good keeper. Oz., 20c; 1/4 lb., $60 \mathrm{c}$; Ib., $\$ 2.00$.
NEW QUEEN.-One of the earliest; small; flat; white; some grow them for pickling. Oz., 20c; $1 / 4$ lb., 50c; 1b., $\$ 1.75$.

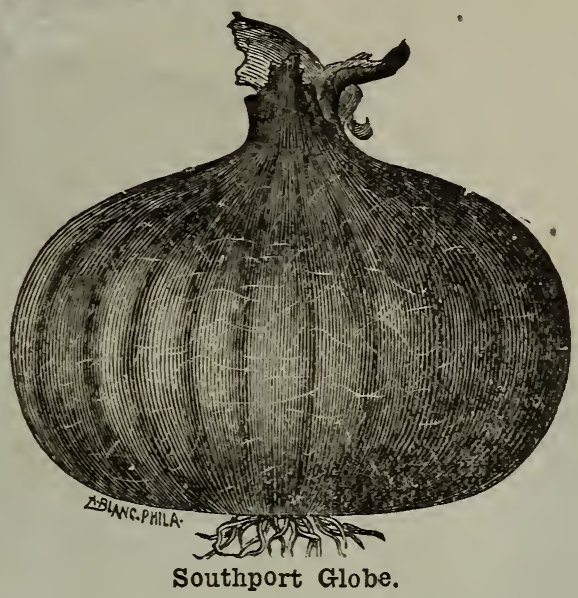

SOUTHPORT WHITE GLOBE.-Is a white, globe shaped onion; produces well; is a good seller; not so good a keeper as the Danvers. Oz., 25c; $1 / 4$ lb., 90c; 1b., $\$ 3.00$.

WHITE FORTUGAL OR SILVER SKIN.-Large, flat, early variety; skin loose; miid flavor; not an extra good keeper: Oz., 20c; 1/4 lb., 60c; lb., $\$ 2.00$.

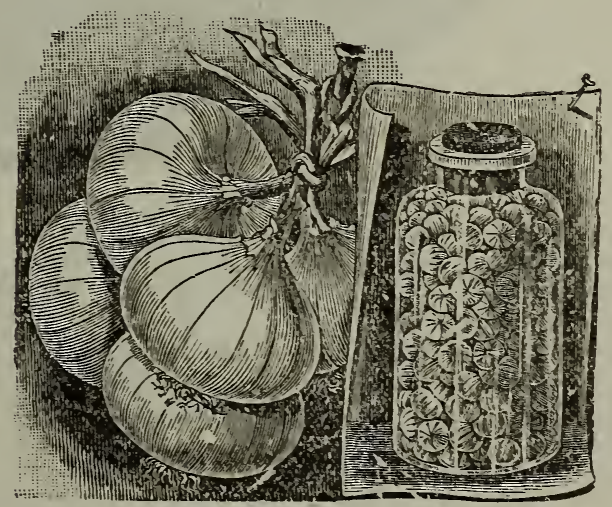

Barletta.

BARLETTA.-A rery early, small, pure white va riety; flesh is firm and mild flaror; used almost exclusively for pickling. Oz., 20c; $1 / 4$ lb., 60c; Ib., $\$ 2.00$.

Prices on Onion Seed Postpaid. 


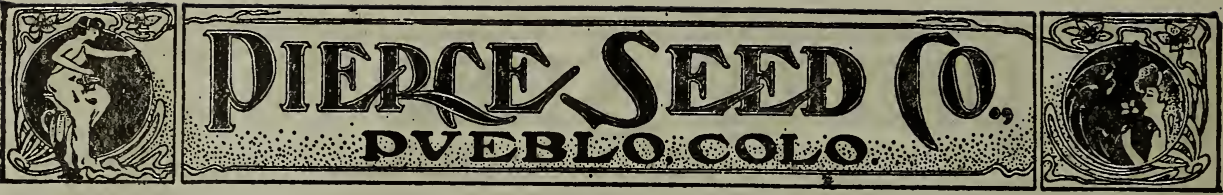

\section{Onions-Continued}

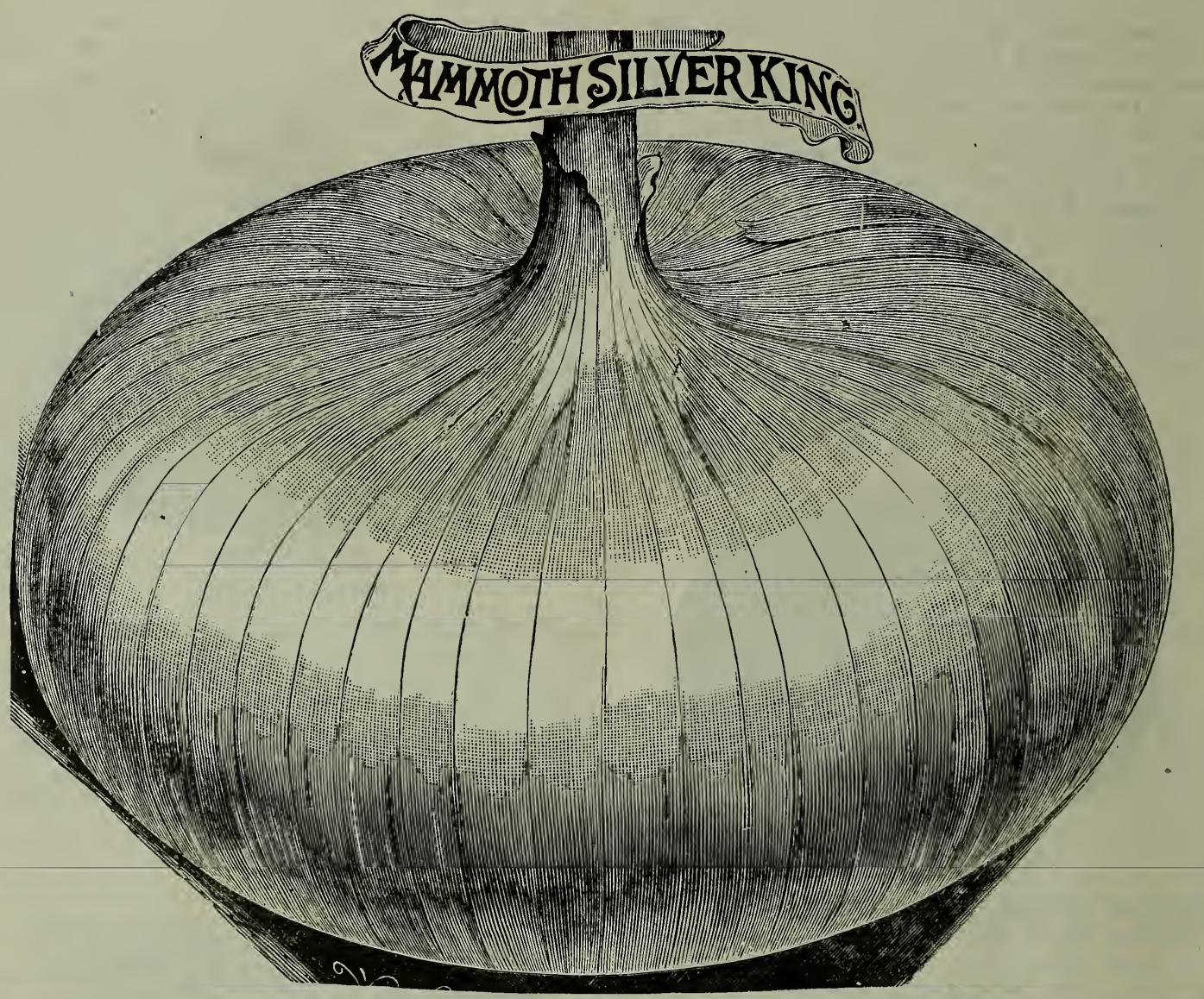

MAMM:OTH SILVER KING.-A large white or silver skin onion; very mild; a fine onion for immediate use, but not a good keeper. Oz., 20c; $1 / 4$ lb., 60c; 1b., $\$ 2.00$.

RED WEATHERSFIELD.-The old standard sort; large size, deep red, thick, approaching to round shape; fine grain and productive. Oz., 15c; $1 / 4$ lb., 50c; lb., $\$ 1.75$.

NEAPOLITAN MARZAJOLA.-A beautiful silvery white skinned variety; not a good keeper; very early; flat. Oz., 20c; 1/4 lb., 50c; 1b., \$1.50.

WHITE LISIRON.-This is a variety grown for green onions, to bunch. They do not bulb, but make a long, white onion, the very best for bunch green onion. Can be sown in the fall and winter over in the ground where grown. Oz., 20c; $1 / 4$ 1b., 65c; 1b., $\$ 2.00$.
AUSTRALIAN BROWN.-This new onion has been thoroughly tried in this locality and proven the best early, long keeping onion grown; the outside skin is a deep amber brown; extremely hard and firm; fine flavor. Oz., 15c; $1 / 4$ lb., $40 \mathrm{c}$; 1b., $\$ 1.50$.

A number of our most progressive gardeners grow their large early onions from sets. Sow seed in hot bed or green house in January and February. When tops are two or three inches high, cut back about one inch from soil with shears or sharp knife, and continue cutting back until time to set out in beds in open ground. The varieties used are Prize Taker, Gigantic, Gibraltar and Mammoth Silver King.

We Prepay Postage on all Garden and Flower Seeds Except Peas, Beans and Corn. Seeds, Bulbs and Plants Can Not Be Sent Parcel Post Rates. 

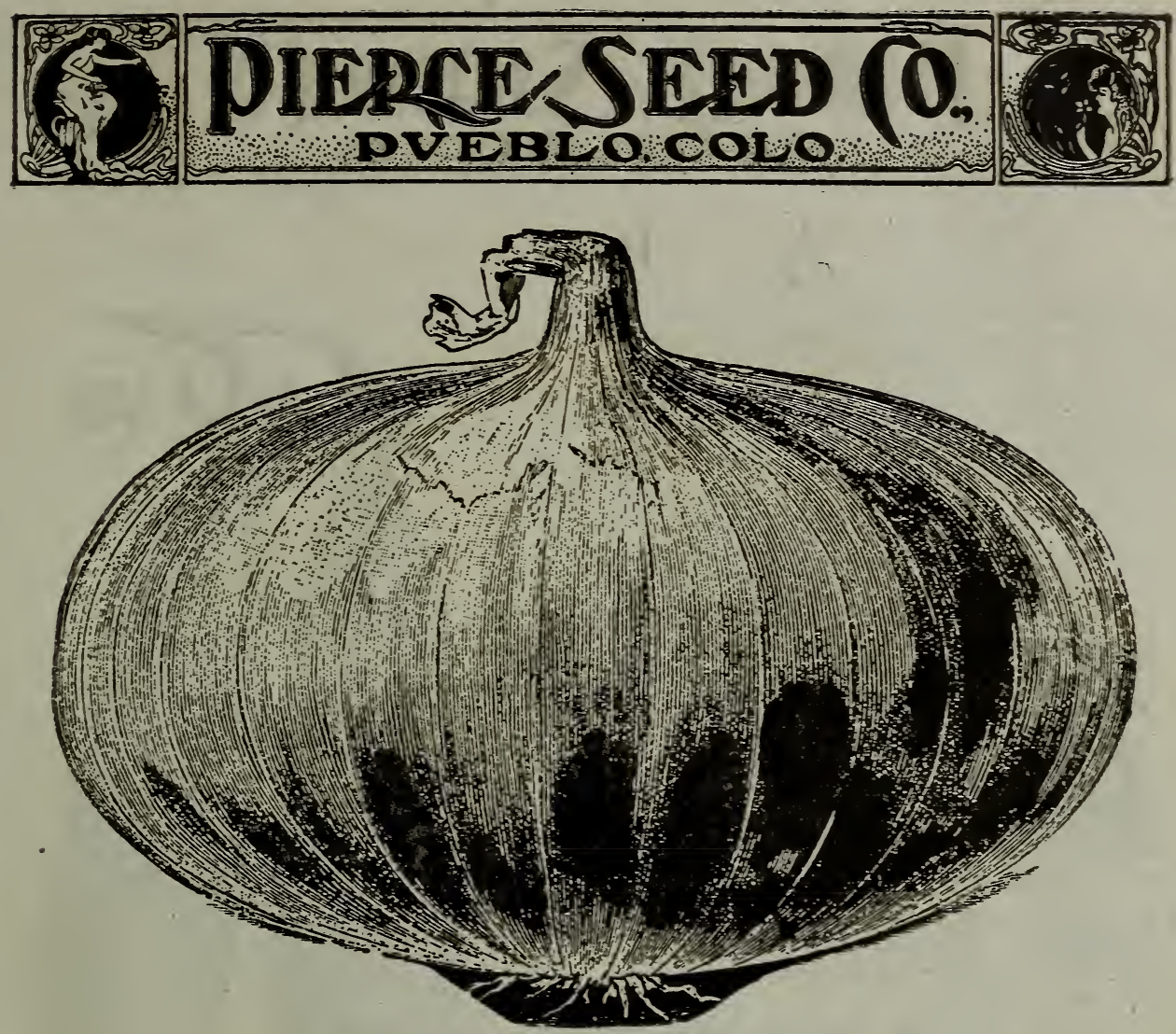

\section{Onions}

(Continued.)

PRIZE TAKER.-This is the early money maker in this locality. Sow early in hot beds and transplant to the open ground as soon as the soil will permit. Our seed of this well estab. lished rariety of onion is of the best. The adjoining picture is a reproduction from a photo. graph taken from onions grown on the St. Charles mesa by one of our market gardeners. The onion is rery large, straw color, and globe shape. Oz., 20c; 1/4 lb., 50c; lb., \$1.75.

GIGANTIC GIBRALTAR.-A very large, white onion, mild flavor and a heary cropper; should be sown in hot bed and trarsplanted. Oz., 25c; $1 / 4$ lb., $75 \mathrm{c} ; \mathrm{lb} ., \$ 2.50$.

WHITE GLOBE.-A large globe shaped onion; firm and fine, of mild flaror, and ecmmanc the highest market price. Oz., 25c; 1/4 lb., 80c; lb., $\$ 2.50$.

\section{Parsley}

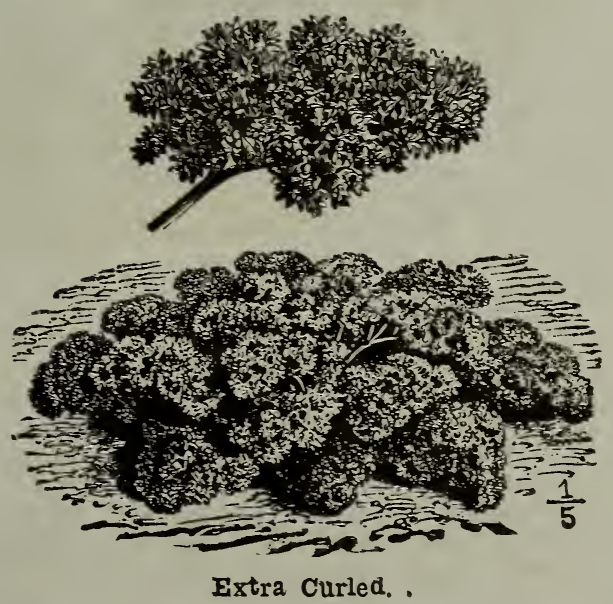

Sow early in spring, after soaking a few hours. Sow in rows one foot apart. One ounce seed will sow 150 -foot drill.

EXTRA CURLED.-Finely eurled variciy. Oz., 10c; $1 / 4$ lb., $25 \mathrm{c}$.

CHAMPION MOSS-Curled; elegant for garnishing. Oz., $10 \mathrm{c} ; 1 / 4 \mathrm{lb}$., $25 \mathrm{c}$.

We Prepay Postage on all Garden and Flower Seeds Except Peas, Beans and Corn. 

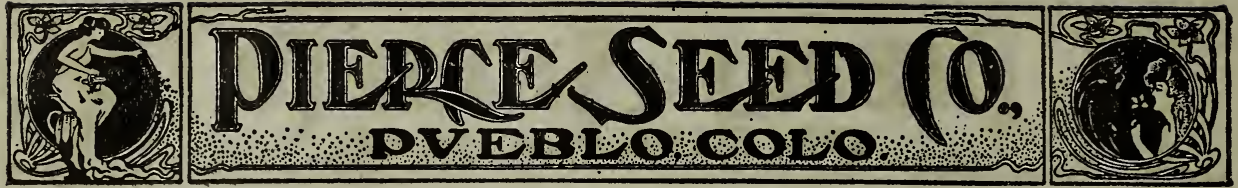

\section{Peas}

For early peas, sow as soon as the ground can be worked, in a warm place. Manure the grouna well, and plant in double rows about 2 or 3 feet apart; they should kept clean, and earthed up twice during their growth.

One pound will sow 50 fect of drill.

Add $8 \mathrm{c}$ per pound if sent by mail.

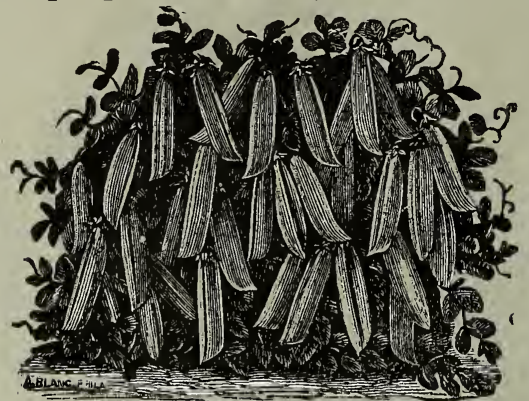

Extra Early Varieties.

ALASKA.-Considered the earliest pea yet brought out; producing pod of good size and well filled, being just the thing for market gardeners. Lb., 15c; 100 lbs., $\$ 10.00$.

AMEER.-A very early and somewhat larger pea than the Alaska, a good vigorous grower, of fine quality. Lb., $20 \mathrm{c}$.

SUTTON'S EXCELSIOR.-(New)-One of the very best early dwarf peas; it combines to a wonderful degree the good qualities of the American Wonder, but the vines are larger and more vigorous; the peas in sweetness and quality are unsurpassed; a fine variety for market gardeners. Ib., 20c.

LAXTON'S ALPHA.-The carliest of all the wrinkled varieties; of fine quality and very prollific. Ib., 20c.

AMERICAN WONDER.-One of the earliest wrinkled peas in cultivation; very productive and sweet; rich in flavor; very compact and dwarf. Lib., 20c.

\section{Second Early Varieties.}

THOMAS LAXTON.-This pea is a very long: green pod; very early for a large podded variety; peas are wrinkled, sweet and tender; a good seller. Lb., 20c.

LAXTONIAN.-The largest podided variety, resembles very much the Gradus. The pods are well filled with large peas of exquisite flavor. Lb., $25 \mathrm{c}$.

EVERBEARING.-A large variety; vines grow from 18 to 24 inches in height; foliage large, so should not be planted too thick for a continuance of bearing; this pea can not be excelled. Lb.. 15c.

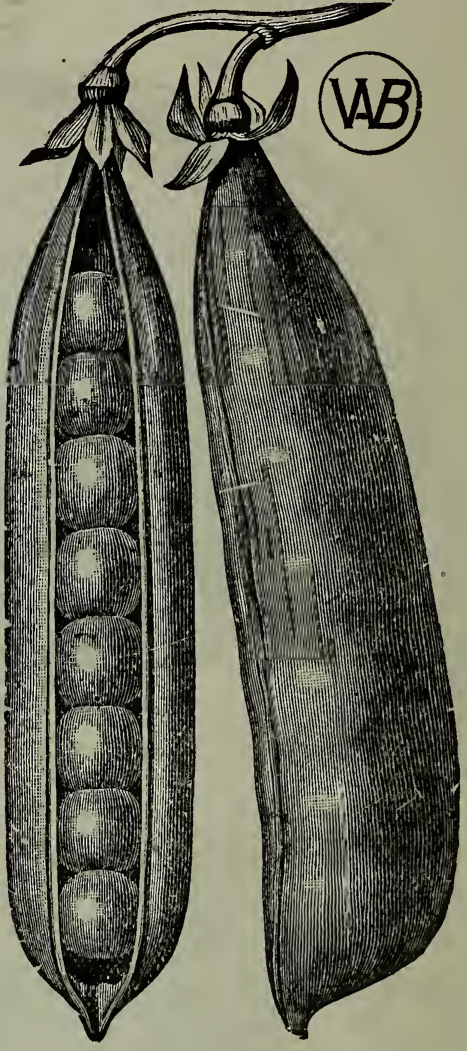

Stratagem.

STRATAGEM IMMPROVED-A ls rge podảed wrinkled pea, fine flavor, vines abouut 18 inches high; productive and a good seller; next to Dwarf Telephone, is probably the best second early for market gardeners' use. Lb., 20c.

DAISY.-The vines growing abouut 18 inches are very stout and bear a good crop of well filled peas. The pods average about 5 inches in length, containing 6 to 9 pods of a light green color, very tender and sweet. Per $1 \mathrm{~b} ., 20 \mathrm{c}$.

CHAMPION OF ENGLAND.-One of the best and most popular peas in cultivation; tall; needs bushing. Lb., 20c.

DWARF FRENCH SUGAR.-Edible Pods.-Can be cooked in the pods or shelled. Lb., 20c.

Peas and Beans in $25 \mathrm{lb}$. Lots at $100 \mathrm{lb}$. Rates.

We Prepay Postage on all Garden and Fl ower Seeds Except Peas, Beans and Corm. 


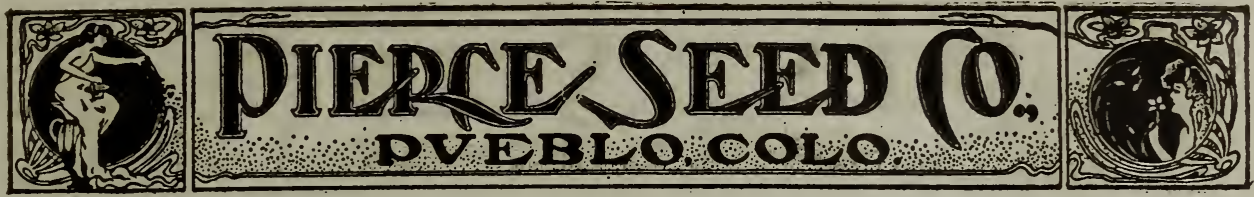

\section{Peas}

(Continued).

GRADUS OR PROSPERITY.-This popular large podded wrinkled pea of the finest quality should be grown by all. It is a good market garden variety and a fine pea for home gardens; strong, heary rines; large pods from 4 to 5 inches long, nearly round, and well filled with very handsome peas of finest flavor. I b., 20 c.

WHITE EYED MARROWFAT.-A very fine, large pea; broad pods, well fil!ed; hardy and productive; the very best for field culture. Market price.

CANADA FIELD.-Used for field culture; when dry are excellent for feeding stock. Market price.

COLORADO FIELD.-The variety that is sown for sheep and hog pasture. Market price.

\section{Pumpkin}

Cultivate same as squash.

One ounce seed to 15 hills.
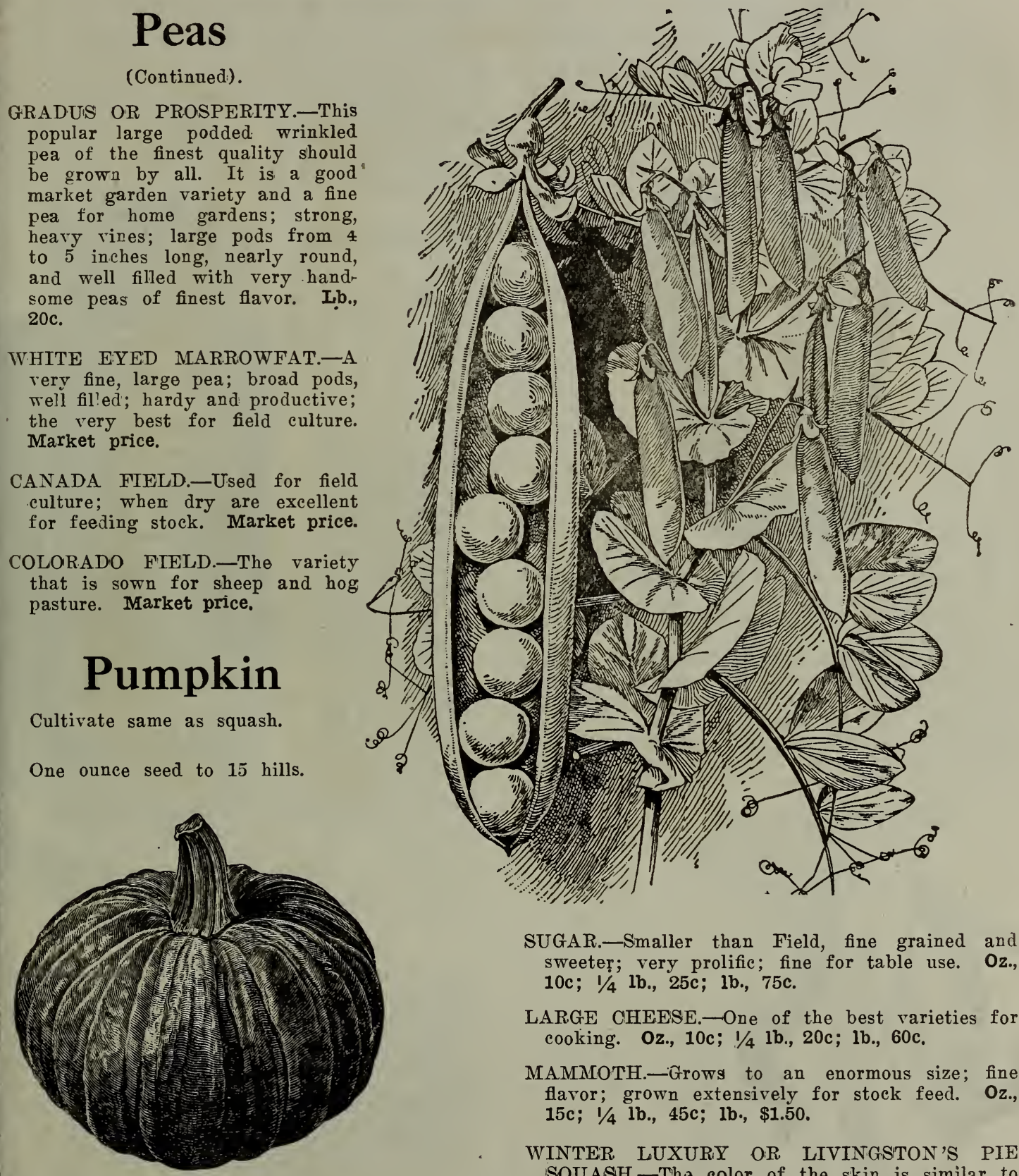

SUGAR.-Smaller than Field, fine grained and sweeter; very prolific; fine for table use. Oz., 10c; $1 / 4$ lb., 25c; 1b., 75c.

LARGE CHEESE.-One of the best varieties for cooking. Oz., 10c; $1 / 4$ lb., 20c; 1b., 60c.

MAMMOTH.-Grows to an enormous size; fine flavor; grown extensively for stock feed. Oz., 15c; $1 / 4$ lb., $45 \mathrm{c}$; lb., $\$ 1.50$.

WINTER LUXURY OR LIVINGSTON'S PIE SQUASH.-The color of the skin is similar to that of the Golden Russet apple; flesh yellow and very thick; medium size; quite early and very productive; rapid and hardy grower; the finest for pies. Oz., 10c; $1 / 4$ 1b., 25c; 1b., 65.

hard shell; excellent for field culture; stock pumpkin. Oz., 5c; 1/4 1b., 10c; 1b., 30c.

CASHAW.-A popular crook-necked variety, tender and of fine flavor. Oz., 10c; $1 / 41 \mathrm{~b} ., 20 \mathrm{c}$; 1b., $60 \mathrm{c}$.

JAPANESE.-A very popular pie pumpkin. Oz., $10 \mathrm{c} ; 1 / 4$ lb., 25c; 1b., $75 \mathrm{c}$. 


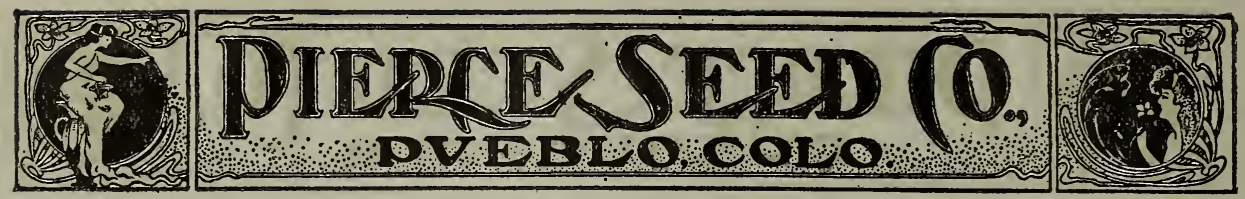

\section{Peppers}

Should be started in a cold frame or hot bed; transplant when three inches high, one foot apart, in drills 20 imehes apart; earth up a little in hoeing, which can be continued until the plants are in full bloom.

One ounce seed for about 1,500 plants.

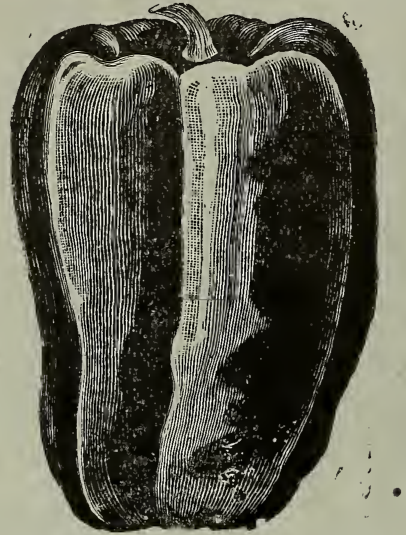

RUBY KING.-Grows to a very large size; the fruits are 6 to 7 inches long by 5 inches through; of a bright red color; very productive; mild and pleaasnt in flavor. $1 / 4$ oz., 10c; $1 / 2$ oz., 15c; oz., 25c.

IMPROVED THICK LONG RED.-Early. About same length of ordinary Long Red Cayenne, but much thicker; two or three times as much meat, and hot. Per 0z., 40c.

CRIMSON GIANT.-A new variety of sweet pepper, which matures very early. The plants are of upright growth and very vigorous. Oz., $40 \mathrm{c}$.

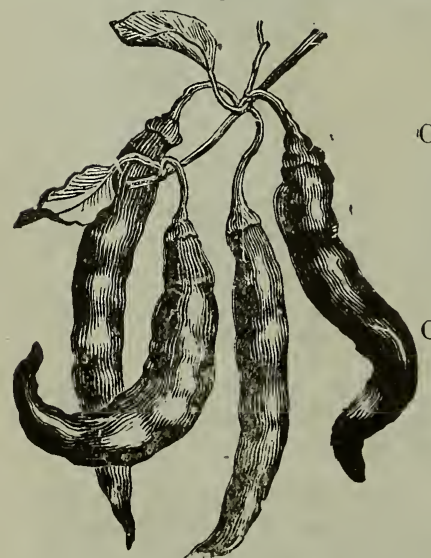

CAA YENNE-Long, red hot and pungent; dwarf. $1 / 4$ oz., 10c; $1 / 2$ oz.,15c; .0z., $25 \mathrm{c}$.

MIAMMOTH GOLDEN QUEEN.-(New). - The largest, handeomest and most productive of all; it and the Ruby King are the largest and best peppers grown-one is a golden yellow and the other is a bright red. Try it. $1 / 4$ oz., $10 \mathrm{c} ; \quad \mathrm{T} / 2$ Oz., 15c; oz., 25c.
RUBY GIANT.-A variety of Mango Pepper, a cross of Ruby King and Chinese Giant; grows to large size and very mild. Oz., 30c.

NEW CHINESE GIANT RED PEPPER.-This is the largest and finest mild red pepper. It is early in ripening and very productive. The plants are vigorous in growth but of stalky habit, seldom growing more than 2 feet high. Price: $1 / 2$ 0z., 25c; oz., 40c.

\section{Parsnips}

\author{
Cultivate $\mathrm{t} \mathrm{h}$ e \\ ground deep, and \\ sow in early spring, \\ in drills 15 inches \\ apart; thin to 6 or 8 \\ inches. \\ One ounce of seed \\ to 200 feet of drill. \\ HOLLOW CROWN. \\ - A great cropper; \\ tender and sweet; \\ c on sidere dhe \\ best for general \\ cultivation; con - \\ sidered superior to \\ all others. Oz., 5c; \\ $1 / 4$ 1b., 15c; 1b. \\ $50 \mathrm{c}$.
}

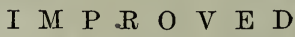
GUER N S E Y. Roots not quite as long as Hollow Crown, but are of greater diameter and more easily gathored; roots smooth and fine grained. Oz., 10c; $1 / 4$ lb., 15c; lb., 50c.

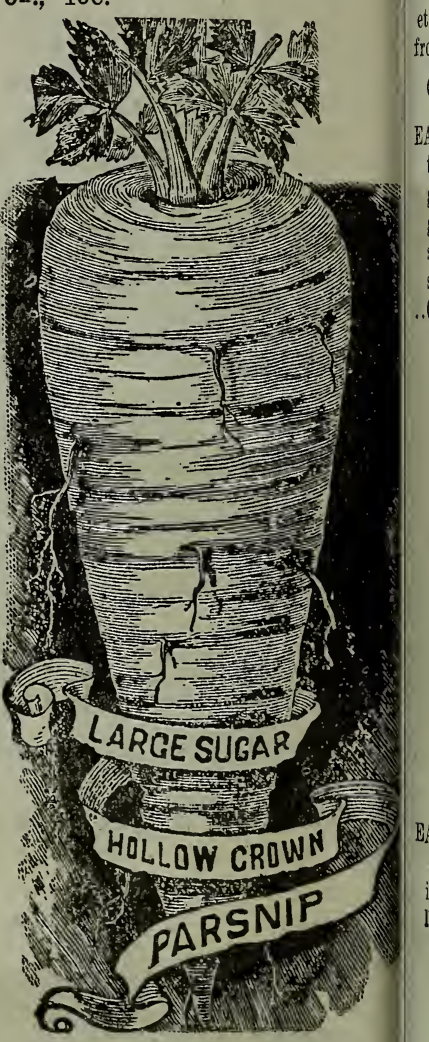

\section{Rhubarb}

Sow in March, in drills a foot apart, thinning out to about the same distance apart in the rows when a few inches high; in fall transplant to about 3 feet apart each way. The large roots are easily forced if packed closely under the stage of a green house or warm cellar, as no light is necessary for tho development of the stalk. LINNAEUS.-Standard variety, tender and juicy. Oz., 1Ec.

CHAMPAGNE.-Medium stalks, rich red color, of very superior quality. Oz., 15c..

SAINT MARTINS.-The earliest, very large 'red stalk, unusually juicy, compact growing, very productive. Oz., 30c.

VICTORIA.-Later than Linnaeus; very large. Oz., 15c; $1 / 4$ lb., $50 c$. 


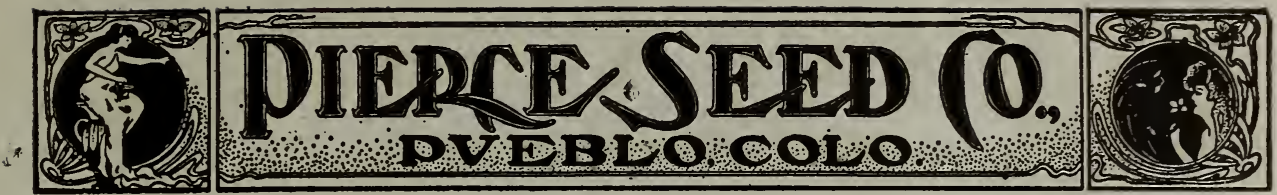

\section{Radish}

Soil for radishes should be light, rich and mellow, as their tender and mild qualities depend upon their rapid growth. Sow as early as the ground can be worked, at intervals of ten to twelve days for a succession. The winter varieties should be sown in August and lifted before frost and stored in the cellar.

One ounce seed for 100-foot drill.

EARLY LONG SCARLET SHORT TOP.-This is the standard variety for market gardeners; grows about 7 inches long, half out of the ground; is brittle and erisp; grows quick; bright scarlet color; tapers regularly to the root; is straight and smooth. Oz., 10c; 1/4 lb., 15c; lb., $.60 c$.
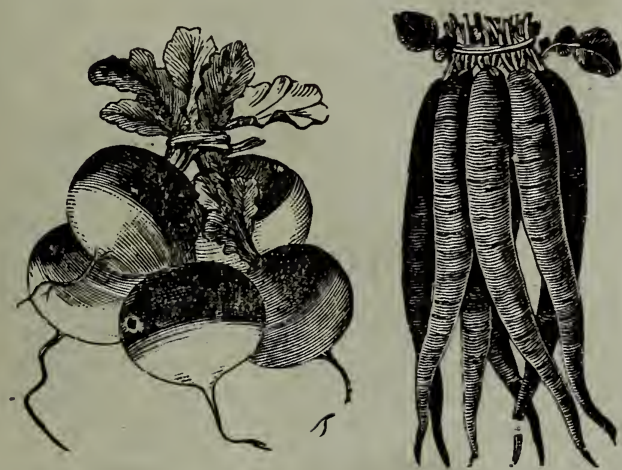

EARLY SCARLET TURNIP WHITE TIP-Same as Early Searlet Turnip but white at: the tip, mak ing it a showy variety. Oz., 10c; 1/4 1b., 25c; lb., $60 \mathrm{c}$.

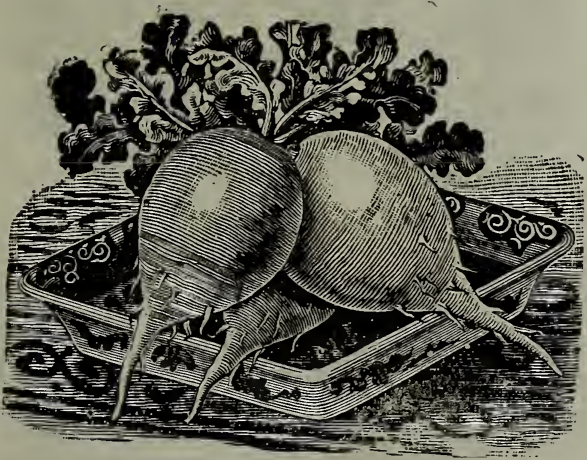

OLIVE SHAPED SCARLET.-Of medium size, of rich brilliant color. Oz., 10z; 1/4 lb., 20c; lb., 60c.

WHITE STRASBURG.-A rery large, white, crisp summer radish. The German favorite. Price: Oz., 10c; 1/4 lb., 25c; 1b., 70c.
CINCINNATI MARKET.-Grows straight and smooth, 6 to 7 inches long. This radish has been grown by Cincinnati, Ohio, gardeners for the past thirty years and is considered far superior to Long Scarlet Short Top. It is an attractive scarlet color, skin is very thin; flesh is crisp, brittle and of delightful flavor, the finest long radish for forcing under glass. Oz., $10 \mathrm{c} ; 1 / 4$ lb., 20c; 1b., 65c.

ICICLE.-One of the best Long White. A rapid growèr. The radishes are long, straight, pure white and about the same size nearly the whole length. Some earlier than White Vienna or Lady Finger. Price: $\mathrm{Oz}, 10 \mathrm{c}$; 1/4 1b., 25c; 1b., 75c.

EARLY SCARLET GLOBE.-The roots of this variety are of slightly olive shape and rich bright scarlet in color; flesh white and tender; fit to pull very early and much larger than Dark Round Red and Early Scarlet Turnip White Tip when matured. One of the best for market gardeners. Price: $\mathrm{Oz}, 10 \mathrm{c} ; 1 / 4 \mathrm{lb} ., 25 \mathrm{c}$; $1 \mathrm{~b} ., 75 \mathrm{c}$.

CRIMSON GIANT.-An early large variety; a beautiful crimson. carmine, turnip shaped; flesh firm, crisp and tender. Oz., 10c; $1 / 4$ 1b., 25c; lb. $7 \mathrm{Cc}$.

EARLY SCARLET TURNIP.-Foreing.-The very best. $\mathrm{Oz}, 10 \mathrm{c} ; 1 / 4 \mathrm{lb} ., 25 \mathrm{c}$; 1b., 75c.

IMPROVED CHARTIER OR SHEPHERD RAD ISH.-Of quick growth; about two-thirds the length being crimson color, shaded off lighter until at the bottom they are white. We can recommend this radish to be one of the best for continuous planting. Oz., 10c; 1/4 lb., 25c; lb., 60c.

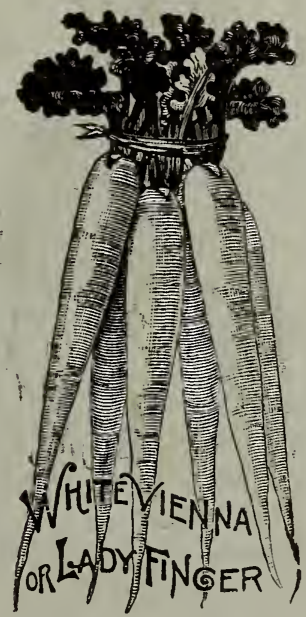

LONG WHITE VIENNA.-This radish is the finest long white radish grown; skin and flesh are pure white; brittle. crisp and of rapid growth. Oz., $10 c ; 1 / 4 \mathrm{lb} ., 20 \mathrm{c} ; 1 \mathrm{~b} ., 60 \mathrm{c}$. 


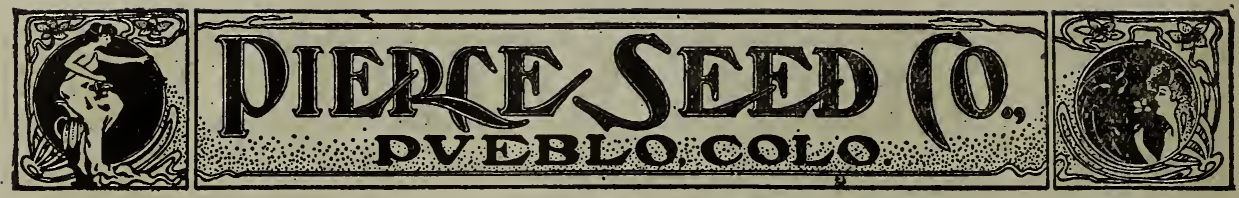

\section{Radish}

(Continued.)

FRENCH BREAKFAST.-A variety of quick growth; mild and tender; good for forcing. Oz., 10c; $1 / 4$ lb., 25c; 1b., 60c.

WOOD'S EARLY F'RAME.-Not quite as long as the Early Long Scarlet Short Top, but thicker; brilliant scarlet color; fine flavor and brittle; a very productive variety. Oz., 10c; $1 / 4$ 1b., 25c; lb., $60 \mathrm{c}$.

GIANT WHITE STUTTGART. -An early and remarkably quick growing turnip shaped radish, the flesh and skin are pure white; crisp and of fine flavor. Oz., 10c; $1 / 4$ 1b., 25c; 1b., 60c.

BLACK ISPANISH.-Long Winter.-One of the hardiest, and best for winter use. Oz., 10c; $1 / 4$ 1b., 25c; 1b., 70c.

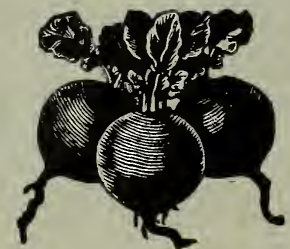

ROUND BLACK SPANISH.- Same quality as Long Black Spanish, the only difference being round in shape. It is the favorite winter radish with many gardeners. Oz., 10c.

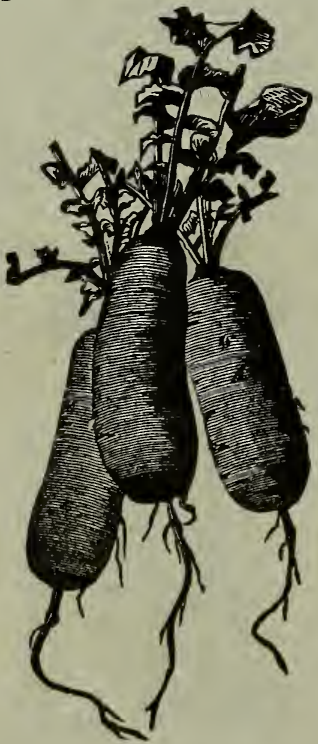

WHITE CHINESE-One of the best winter radish; stump rooted, solid, crisp and of a mild flavor. Oz., 10c; 1/4 1b., 25c; 1b., 70c.

DHINA ROSE.-Winter.-Grows large and tender; is becoming a very popular variety; half long; very smooth; firm and tender and of fine flavor. Oz., 10c; 1/4 1b., 25c; 1b., 70c.

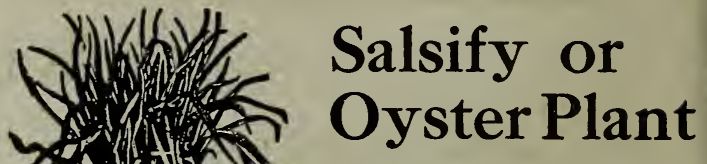

Sow on rich soil early in spring, in drills 14 inches apart; the roots will be ready in October, and can be left in the ground until spring.

One ounce of seed will sow 50 feet of drill.

MAMMOTH SANDWWICH ISLAND.-A new and larger growing variety than the old sort. Oz., 20c; $1 / 4$ lb., 40c; 1b. $\$ 1.50$.

\section{Spinach}

For summer use sow early in the spring in drills 8 inches to 1 foot apart; cover the seed one inch. For very early spring use, sow in August or September; cover lightly with straw.

One ounce seed will sow 50 feet of drill.

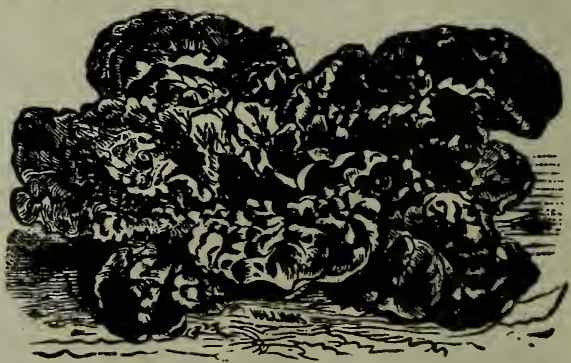

LONG STANDING.-The leaves are thick and of excellent flavor; is noted for being the latest to run to seed; desirable. Oz., 5c; $1 / 4$ 1b., 15c; $1 b$. $35 c$.

ROUND LEAVED.-Excellent market sort; equally good for spring and fall sowing; leaves large, thick, fleshy. Oz., 5c; 1/4 lb., 15c; 1b., 35c.

THICK LEAVED VIROFLAY.-This in very large and thick leaved; good for fall or spring sowing. Oz., 5c; 1/4 1b., 15c; 1b., 35c.

HENDERSON'S NORFOLK SAVOY LEAVED.Very productive; leaves curled like Savoy Cab bage. Oz., 5c; 1/4 1b., 15c; 1b., 35c.

5 Pounds one variety, $\$ 1.50$. 

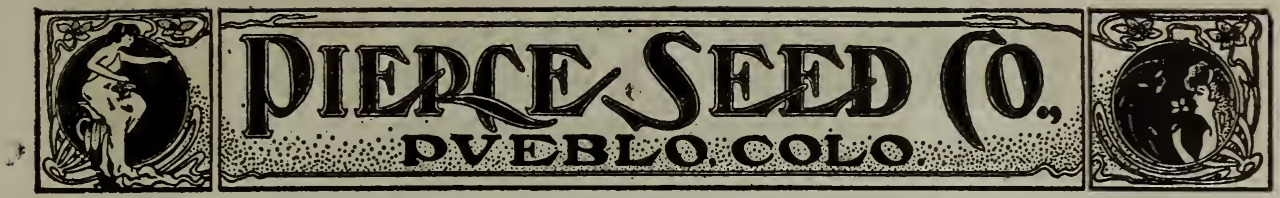

\section{Squash}

Sow about the middle of spring in hills, the early sort about 4 feet apart, and the late varieties 6 to 8 feet; drop enough seeds to be thinned to three plants to a hill.

One ounce seed for 15 hills for large variety. One ounce seed to 40 hills for bush varieties.

EARLY WHITE BUSH OR WHITE PATTY PAN. -Light cream color, flat and scalloped shaped. Oz., 10c; 1/4 1b., 25c; lb., 75c.

GOLDEN BUSH.-A fine early summer sort; yellow; fine flavored. Oz., 10c; 1/4 1b., 25c; 1b., 75c. WAMMOTH CHILE-Grows to an immense size; exce lent, for all purposes. Oz., 10c; $1 / 4 \mathrm{lb} ., 30 \mathrm{c}$; 1b., $\$ 1.00$.

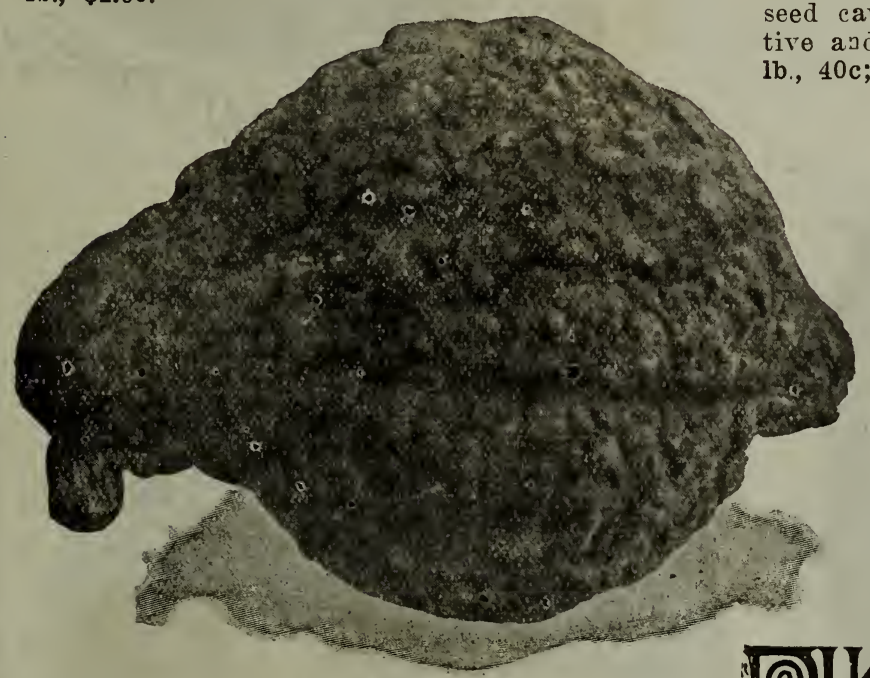

Hubbard.

MARBLEHEAD.-Has a gray, hard shell; resembles the Hubbard in shape; is a good keeper. Oz., 10c; 1/4 1b., 25c; 1b., 75c.

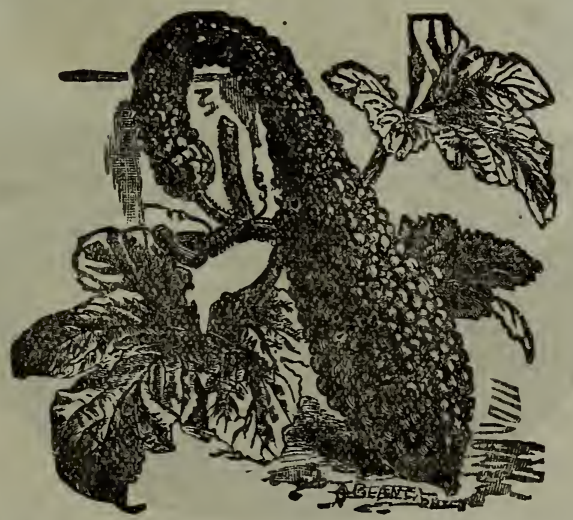

SUMMER CROOKNECK.-Very productive; small crookneck; yellow color; shell very hard when ripe. Oz., 10c; $1 / 4$ 1b., 25c; 1b., $75 c$.
BOSTON MARROW.-One of the very best for fall and winter use; form ovate pointed; rind thin, bright orange; flesh is deep orange; finc grained; excellent flavor. Oz., 10c; 1/4 lb., 20c; lb., 65c.

BUTMAN.-In size and productiveness it resem. bles the Hubbard; has a thick shell and is thick meated; shell is of a bright grass green color, intermixed with white; a good keeper. Oz., 10c; $1 / 4$ 1b., 25c; 1b., 75c.

FORDHOOK.-A strong and rapid grower; earlier in ripening than any other winter squash; the color is bright yellow outside and straw color within; the skin is very thin, meat thick, and seed cavity small; this variety is very productive ayd one of the best keepers. Oz., 15c; $1 / 4$ lb., 40c; 1b., \$1.25.

HUBBARD.-Leading squash for fall and winter use; hard skinned; splendid keeper; flesh dark yellow; fine grained; dry, sweet and rich. Oz., 10c; 1/4 1b., 30c; lb., $\$ 1.00$.

HUBBARD. - (Chicago Warted). Large, blackish green; hard as wood, with warty knobs all over it. Oz., 10c; .1/4 1b., 35c; 1b., $\$ 1.00$.

TURBAN. - Flesh orange yellow; thick; fine grained and well flav ored. Oz., 10c; 1/4 1b., 25c; 1b., 65c.

VEUETABLE MARROW.-A favorite English variety, bearing freely, oblorg, dull yellow fruits, 10 to 15 inches in length, 4 to 5 inches in diameter; flesh before being quite ripe, tender, marrowy and delicious. Oz., $15 \mathrm{c}$.

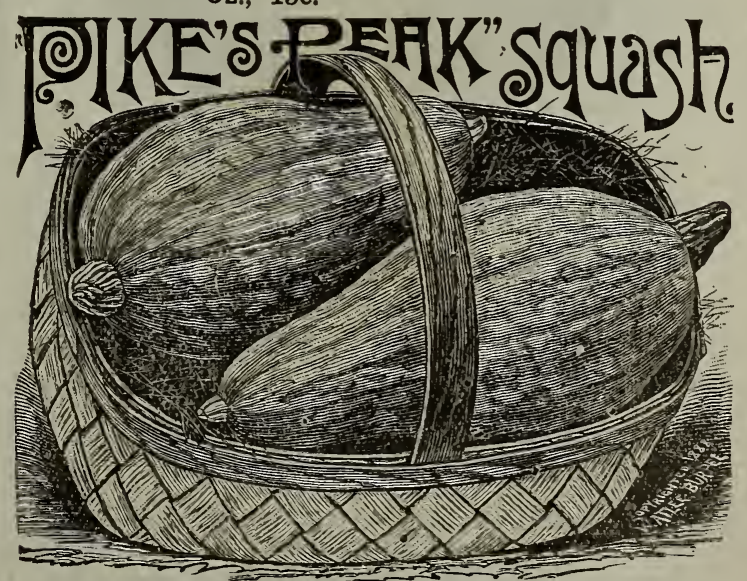

SIRLEY OR PIKE'S PEAK.-Shell is a pale slate col r; very hard, but so smooth and thin there is no waste in baking; flesh is solid and thick, a brilliant orange color, dry, and of a rich, delicate flavor. Plant plenty of seed as they are more difficult to germinate than others. Oz., $10 \mathrm{c} ; 1 / 4$ 1b., 30c; 1b., $\$ 1.00$. 


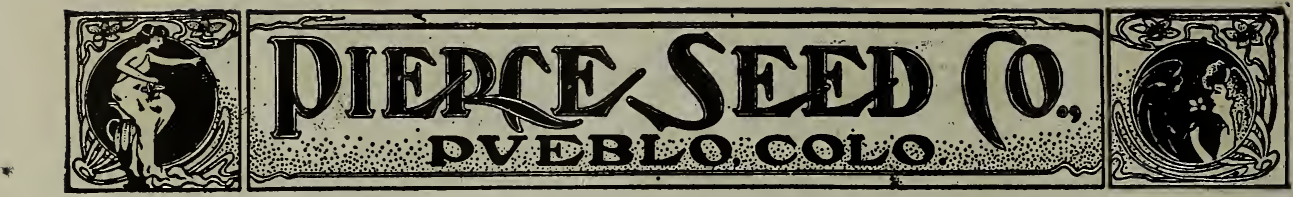

\section{Tomato}

For early use sow in hot beds or box in a sunny exposure in the house; they grow much better if transplanted when 2 or 3 inches high; when 5 or 6inches high, if the ground is warm, transplant to the open ground, on a cloudy day if possible. Set the plants about 4 feet apart each way, on mounds, so that the sunlight will reach the vines more rapidly. One ounce seed for 2,000 plants.

EARLY ACME.-A standard variety; very productive; fruit of mediam size; round and smooth; color dark 'purplish red; bears continually until frost; no core; splendid for market. Oz., 20c; 1/4 1b., 60c.

SPARK'S EARLIANA.-This variety is extra early; good size and flavor; bright red. Oz., 30c.

JUNE PINK.-Oz., 30c.

CHALK'S EARLY JEWEL.-Oz., 20 c.

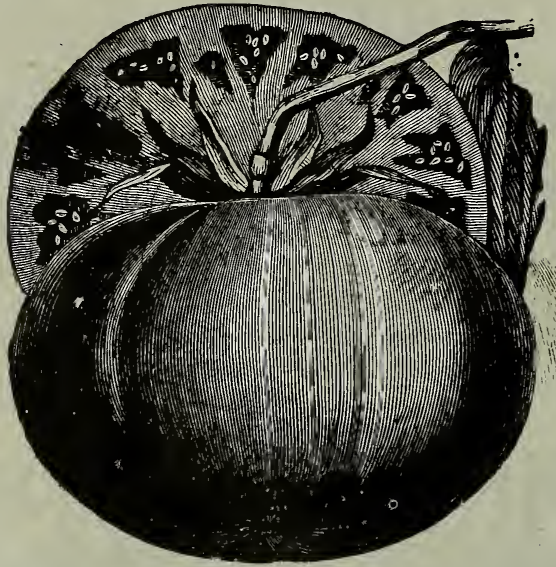

* LIVINGSTON'S BEAUTY.-Color very glossy crimson with a light tinge of purple; very productive; ripens very early and evenly; free from rot; a splendidl keeper. Oz., 20c; 1/4 lb., $60 \mathrm{c}$.

PEAR SHAPED YELLOW.-Used for preserving, same as figs. Oz., 30c; $1 / 4$ 1b., $\$ 1.00$.

PEACH.- (New). - Resembles the peach in shape and color; about 2 inches in diameter; of a deep rose lcolor; exce!lent for preserves, also for canning. Packet, 10c; 0z., 35c.

* LIVINGSTON'S. ROYAL RED.-A new variety; fruit large; perfectly smooth; of a vivid red color without any purple tinge; a good tomato for shipping, : canning or slicing for table use. Oz., 20c; $1 / 4$ lb., $60 c$.

* Canning varieties.
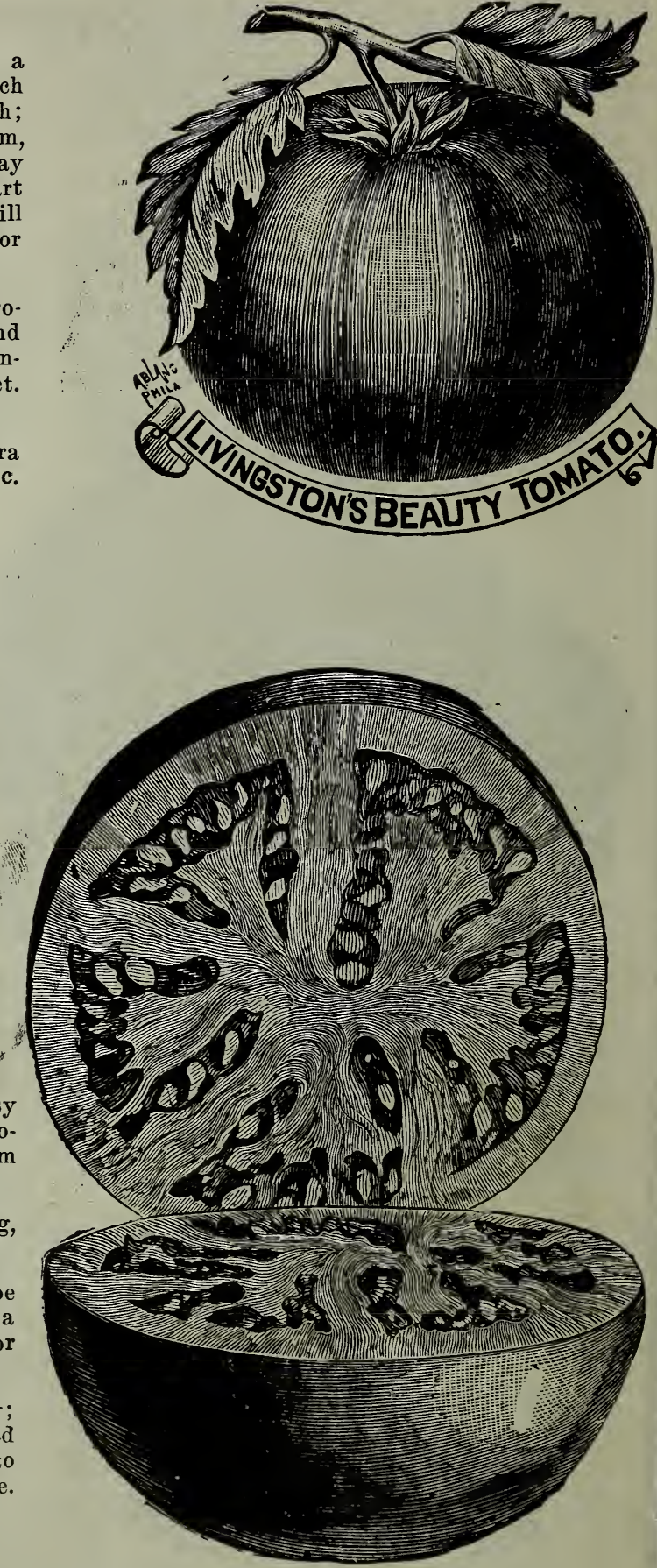

We Prepay Postage on all Garden and Flower Seeds Except Peas, Beans and Corn. 


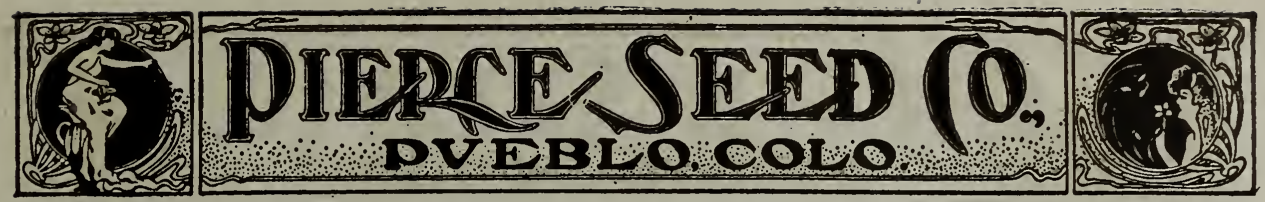

\section{Tomato}

(Continued.)

*THE STONE.-As its name indicates, it is very large, solid and heavy; very smooth and of a bright scarlet color; ripening evenly to the stem without a crack; fine for canning and good for general crop; a good shipper. Oz., 20c; 1/4 lb., $60 \mathrm{c}$.

IMPROVED DWARF CHAMPION.-Is of a dwarf, stiff habit, needing scarcely any support; it is very early and wonderfully prolific; a deep red, medium size, round and smooth; very few seeds. Oz., 30c; 1/4 lb., $\$ 1.00$.

LIVINGISTON'S NEW DWARF STONE.-The Dwarf Stone is fully double the size of Dwarf Champion, and yet equally as early. It is fully .as prolific and more productive. The largest fruited upright growing variety in existence. Package, 10c; oz., 25c.

Prices on Tomato Seed Postpaid.

* Canning varieties.

\section{Tobacco}

CONNECTICUT SEED LEAF.-Oz., 25c.

HAVANA.-Oz., 40c.

\section{Turnips}

For the spring crop sow as early as the seed can be got into the ground, in 14-inch drills, thin to 5 or 6 inches. For the fall erop sow from the middle to the last of July, for a succession, at intervals of two weeks. As the seed is very fine, it requires to be covered very thin.

One ounce seed sows 100 feet of drill. One pound of seed to the acre.

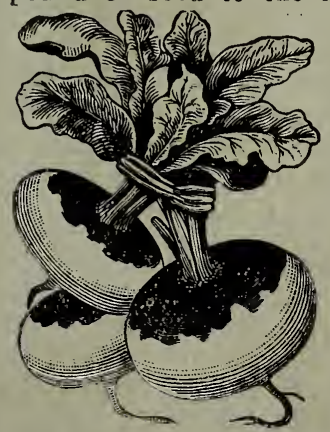

PURPLE TOP MILAN.An early strap leaf variety; the bulbs are white with purple top; round, flattened and solid; very slender tap root; flesh pure white, sweet and crisp. Oz., 10c; $1 / 4$ lb., 35c; 1b., $\$ 1.00$.

EARLY PURPLE TOP MUNICH.-Is very early, with a bright purple top and fine, mouse tailed root; flesh white and of a delicious flavor. Oz., $10 \mathrm{c} ; 1 / 4 \mathrm{lb} ., 25 \mathrm{c} ; 1 \mathrm{~b} ., 80 \mathrm{c}$.

EARLY W:HITE FLAT DUTCH.-An early white fleshed variety of quick growth; excellent quality. Oz., 10c; 1/4 1b., 20c; lb., 50c.

EARLY WHITE EGG.-It is perfectly smooth, of a pure, clear white, grows half above the ground; of excellent flavor; a first rate keeper. Oz., 10c; 1/4 lb., 20c; 1b., 60c.
PURPLE TOP WHITE GLOBE.A very rapid grower; for early or late sowing. Oz., 10c; $1 / 4$ lb., 20c; 1b., 60c.

PURPLE TOP STRAP LEAF.-A rapid grower and a standard variety; flat. Oz., 10c; $1 / 4 \mathrm{lb}$, 20c; 1b., 60c.

YELLOW GLOBE:-One of the best varieties for general use. Oz., 10c; 1/4 lb.,20c; 1b.,60c.

IMPROVED GOLDEN BALL-Rich and sweet; unsurpassed for its quick growth and excellent quality; keeps well. Oz., 10c; 1/4 Ib., 20c;. 1b., $60 \mathrm{c}$.

YELLOW ABERDEEN.-Very hardy and productive; good keeper; globe shaped; fine quality. Oz., 10c; 1/4 lb., 20c; 1b., 60c.

WHITE GLOBE.-Globe shaped; good for table or stock use; grows large. Oz., 10c; $1 / 4$ lb., 20c; lb., 60c.

COW HORN.-Matures quickly; flesh white; fine grained; : sweet; excellent for table use. Oz., 10c; $1 / 4$ lb., 20c; 1b., 50c.

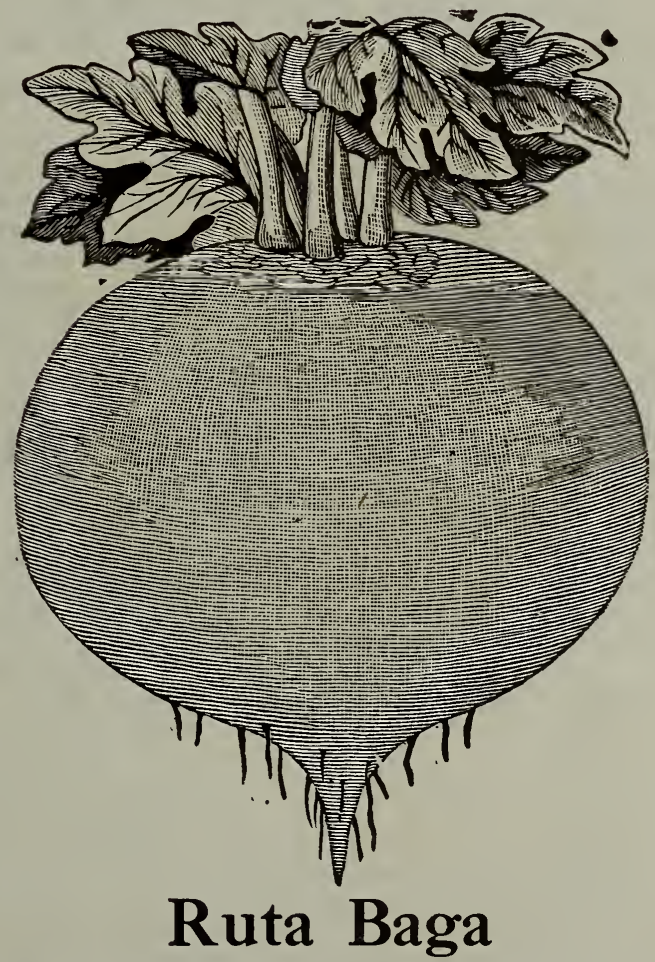

Ruta Baga should be sown earlier than fall and winter turnips. During the month of June is the best time. Cultivate same as turnip. except drills should be 20 inches apart. Thin.to 8 inches. AMERICAN YELLOW.--Very hardy and productive; flesh yellow, solid, sweet fine flavored. Oz., 5c; $1 / 4$ lb., 15c; 1b., 60c.

SKIRVING'S YELLOW PURPLE TOP.-Flesh yellow, of solid texture; very popular variety. Oz., 5c; 1/4 lb., 15c; lb., 60c. 


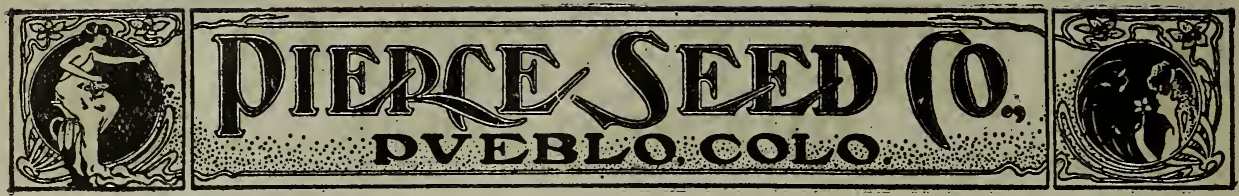

\section{Onion Sets}

Onion sets, if sent by mail, must be accompanied with $8 \mathrm{c}$ per lb. to pay postage.

YELLOW BOTTOM SETS.-15c lb.; 2 lbs, for 25c. RED BOTTOMI SETS.-15c lb.; 2 lbs. for 25c.

TOP SETS, RED.-15c lb.; 2 lbs. for $25 \mathrm{c}$.

WHITE BOTTOM SETS.-15c lb.; 2 lbs. for $25 \mathrm{c}$. GARLIC.-15c per $1 \mathrm{~b}$.

\section{Pop Corn}

Add $8 \mathrm{c}$ per pound if sent by mail.

WHITE RICE POP CORN.-One or the very best varieties grown; a sure eropper and always finds ready sale. Per $1 b ., 10 c$.

QUEEN'S GOLDEN.-This is a very fine Pop Corn; color a delicate golden yellow; pops out white and large; is very tender. Ib., 10c.

\section{Russian Sunflower}

Raised extensively for chicken feed; does well in low spots. Ib., 15c.

Add $8 \mathrm{e}$ per pound if sent by mail.

\section{Buckwheat}

JAPANESE.-(New).-The kernels of this new Euckwheat are nearly twice as large as the common kind; it branches more and need not be sown as thickly. It is a very heavy cropper and less apt to blight than other varieties. Market price.

SILVER HULLTD.-Mar-et price.

\section{Aromantic, Medicinal and Pot Herbs}

Sow in the spring in shallow drills 1 foot apart; when well up thin out or transplant to a proper distance apart. Gather on a dry day just before they come into full bloom.

Per $\mathrm{Oz}$

A.NISE - The leaves used as a garnish and seasoning; the seeds made into tea as a tonic ....................... .10

BALM.-Principally used for making balm tea $\ldots \ldots \ldots \ldots \ldots \ldots \ldots \ldots \ldots \ldots$

CARAWAY.-The seeds are used medicinally

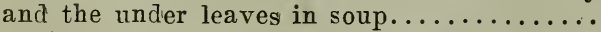

CATNIP.-A favorite medicinal herb........

DILL. - The leaves are used in soups and sauces and to put along with pickles........

HOREHOUND.-Used as a tonic; also in case

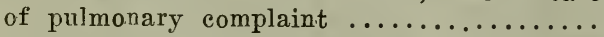

HYSSOP.-The leaves are gathered for making Hyssop tea and for other purposes.....

RUE-Used for medicinal purposes; also

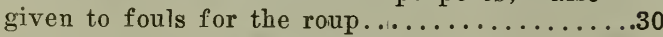

THYME.-Sweet; used for seasoning. Thyme tea is a cure for nervous headache....... SAGE.-The leaves are used for seasoning, stuffing, etc. Tea made from the leaves is

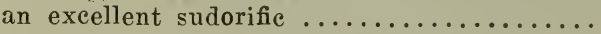

SAVORY SUMMER.-Leaves for culinary purposes. If finely powdered and sealed tightly in glass bottles, will retain their

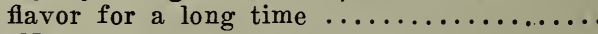

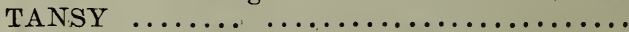

WORMWOOD.-Used for medicinal purposes. It is also beneficial to poultry, and should be placed in poultry yards .............

\section{Plants and Roots}

\section{ASPARAGUS ROOTS.}

Cabbage, Celery, Cauliflower, Eggplant, Pepper and Tomatoes are transplanted plants. On seedbed stock we can make special prices.

(Special price in large quantities).

Per Per

Asparagus Roots, 1 year old, by express ....................... $\$ .20 \$ .60$

Asparagus Roots, 2 years old, by ex-

press ...................... .25 CHIVES.

Chives or Schnittlauch .......... .20 HORSERADISH.

Horseradish .... ............ .25 RHUBARB

1.50

Rhubarb ............

.50

3.50

\section{CABBAGE.}

Cabbage, Jersey Wakefield ......... .10

Cabbage, Early Summer ............ . 10

Cabbage, Late Varieties ........... .10 .75 .75 .75

Cabbage, Late Varieties, large quan-

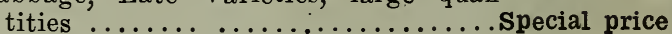
CELERY.

Celery, Early White Plume ......... .15 ..1.00

Celery, Golden Self Blanching ............ 15 1.50

Celery, Giant Pascal ................. 151.00

CAULIFLOWER.

Cauliflower, Early Snowball ........ . .15 1.75 EGG PIANT.

Egg Plant, New York Purple....... .25 PEPPERS.

Peppers, Cayenne ................15

Peppers, Ruby King ...............15 TOMATO TRANSPLANTED.

Tomato, Early Acme ,............... $10 \quad .70$

Tomato, Dwarf Champion ........... $.10 \quad .70$

Tomato, Beauty .......................... $\quad .70$

Tomato, Mangus ................. .10 $\quad .70$ STRAWBERRY PLANTS.

Bederwood ...... SWEET POTATO PLANTS.

In season. 40c per 100 .

All planits are hardened before shipment, and will be carefully packed.

Above prices good until stock is sold out. No extra charges for boxing or packing.

Special price per 1,000 on all plants. HOT BED SASH.

.40 Three feet wide, 6 feet long, $1,1 / 4$ inches thick, not glazed .................. \$1.40 Three feet wide, 6 feet long, $13 / 4$ inches thick, not glazed ..................\$1.60 


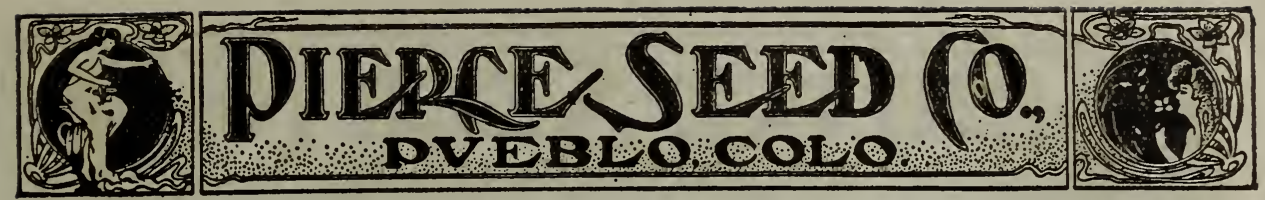

\section{About Seeds And Plants}

Seeds to Lb. Price Lb.

Ash, White ............ 10,000

Box Elder ............ 15,000

Black Locust ........... 30,000

Catalpa ................ 20,000

Honey Locust .......... 2,500

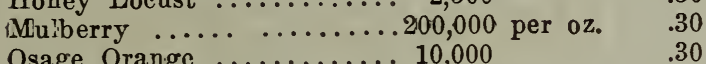

Osage Orange $\ldots \ldots \ldots \ldots \ldots 10,000$

$\$ .40$

.35

.35

1.50

.30

Average Quantity of Seed Sown to an Acre.

\section{IN DRILLS.}

Dwarf Beang .............. 75 to $90 \mathrm{lbs}$. Eary Peas ................ 75 to $95 \mathrm{lbs}$.

Marrowfat Peas .............. 70 to $90 \mathrm{lbs}$.

Beets .................. 4 to $5 \mathrm{lbs}$.

Mangel Wurzel ............. 6 to $8 \mathrm{lbs}$.

Carrots .................. 2 to 3 lbs.

Onions ................... 4 to 5 lbs.

Onions for Sets ............ 20 to $30 \mathrm{lbs}$.

Onion Sets ................. 300 to $500 \mathrm{lbs}$.

Parsnips .................. 4 to $5 \mathrm{lbs}$.

Radish ................ 6 to $8 \mathrm{lbs}$.

Ruta Baga ..................... 1 to $1 \frac{1}{2} \mathrm{lbs}$.

Spinach ................. 10 to 12 lbs.

Salsify ................ 10 to 12 lbs.

Turnips ........................ 1 to $1 \frac{1 / 2}{16}$ lbs.

Tomatoes to Transplant ......... 4 oz.

\section{IN HILLS.}

Corn .................. 8 to $10 \mathrm{lbs}$.

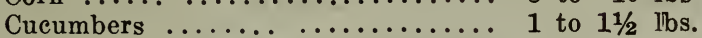

Musk Melons .............. 1 to 2 lbs.

Watermelons $\ldots \ldots \ldots \ldots \ldots \ldots \ldots \ldots$. 2 to 4 lbs.

Pumpkins ................. 2 to 4 lbs.

Squash $\ldots \ldots \ldots \ldots \ldots \ldots \ldots \ldots \ldots$ to $3 \mathrm{lbs}$.

Quantity of Seeds Requuired to a Given Number of Plants.

Asparagus ............. oz. to

Cabbage .............. 1 oz. to

Cauliflower ............. 1 oz. to

Celery .............. 1 oz. to

Endive $\ldots \ldots \ldots \ldots \ldots \ldots \ldots$ oz. to

Egg Plant ............ 1 oz. to

Leek ............... 1 oz. to

Lettuce ............. 1 oz. to

Majoram ............. 1 oz. to

Pepper .............. 1 oz. to

Tomatoes ............ 1 oz. to

Thyme ............... 1 oz. to 5,000 plants

Tobacco ............. 1 oz. to 15,000 plants

Sage .............. 1 oz. to 1,000 plants

Savory ............. 1 oz. to 500 plants

Rhubarb ............... 1 oz. to 500 plants
The Number of Plants, Etc., Required to Set an Acre.

1 foot by 1 foot $\ldots \ldots \ldots \ldots \ldots \ldots \ldots 43,560$

$11 / 2$ feet by $11 / 2$ feet $\ldots \ldots \ldots \ldots \ldots \ldots \ldots 19,360$

2 feet by 2 feet $\ldots \ldots \ldots \ldots \ldots \ldots \ldots 10,809$

$21 / 2$ feet by $21 / 2$ feet $\ldots \ldots \ldots \ldots \ldots \ldots \ldots \ldots, 670$

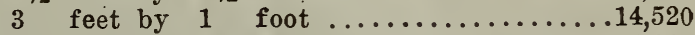

3 feet by 2 feet $\ldots \ldots \ldots \ldots \ldots \ldots \ldots 7,260$

3 feet by 3 feet $\ldots \ldots \ldots \ldots \ldots \ldots \ldots 4,480$

4 feet by 4 feet $\ldots \ldots \ldots \ldots \ldots \ldots \ldots 2,722$

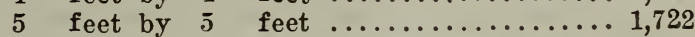

6 feet by 6 feet $\ldots \ldots \ldots \ldots \ldots \ldots \ldots 1,200$

9 feet by 9 feet $\ldots \ldots \ldots \ldots \ldots \ldots \ldots 537$

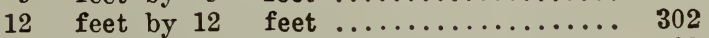

15 feet by 15 feet ................ 193

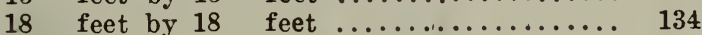

20 feet by 20 feet $\ldots \ldots \ldots \ldots \ldots \ldots \ldots, 108$

25 feet by 25 feet $\ldots \ldots \ldots \ldots \ldots \ldots \ldots$. 70

30 feet by 30 feet $\ldots \ldots \ldots \ldots \ldots \ldots \ldots .40$

40 feet by 40 feet ............... 27

Weights and Measures and Amount of Seeds Sown to the Acre.

Alfalfa Clover .......6 $60 \mathrm{lbs} . \ldots \ldots, 15$ to 20

Red Clover ..........6. 60 lbs....... 12 to 15

White Clover ........6 $60 \mathrm{lbs} . \ldots \ldots 66$ to 8

Alsike Clover .........60 lbs....... 6 to 8

Timothy...........45 lbs....... 20 to 25

Blue Grass .......... 14 lbs....... 30 to 40

Red Top ................ 14 Ibs..... 30 to 40

Mixed Lawn Grass ..... 14 lbs....... 30 to 40

English Rye Grass ..... $20 \mathrm{lbs} . \ldots . .20$ to 64

Oats ..................... 32 lbs..... 32 to 65

Barley .................... 48 lbs...... 60 to 90

Corn ................. 56 lbs..... 8 to 10

Evergreen Millet ....... $20 \mathrm{lbs} . . . \ldots 20$ to 30

Hemp ............ 44 lbs...... 32. to 55

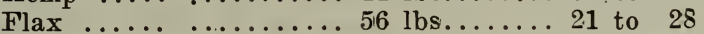

Buckwheat .......... 52 lbs....... 36 to 52

Esperette Clover ...... $28 \mathrm{lbs} . \ldots \ldots 20$ to 30

Orchard Grass ......... $14 \mathrm{lbs} . \ldots \ldots .20$ to 30

Hungarian .......... $48 \mathrm{lbs} \ldots \ldots 25$ to 30

Common Millet ........ 50 lbs........ 20 to 30

German Millet ........ 50 lbs...... 25 to 30

Rye ............ $56 \mathrm{lbs} \ldots \ldots \ldots .75$ to 90

Wheat .............6. $60 \mathrm{lbs} . \ldots 60$ to 80

Sugar Beets ......... ....... 6 to 8

Peas, Field ............ 50.1bs....... 90 to 120

Top Onion Sets .......29 29 lbs.....250 to 300

While we exercise the greatest care to have all the seeds pure and reliable, we do not give any warranty, express or implicd. If tho purchaser does not accept the seeds on these terms and conditions, they must be returned at once, and the money that has been paid for same will be refunded.

Such as Dutch Hyacinths, Crocus, Tulip, Narcissus, Jonquils, Daffodils, must be planted out doors in the fall for early blooming. We import direct and can furnish choice bulbs. Write us for price list this fall. 


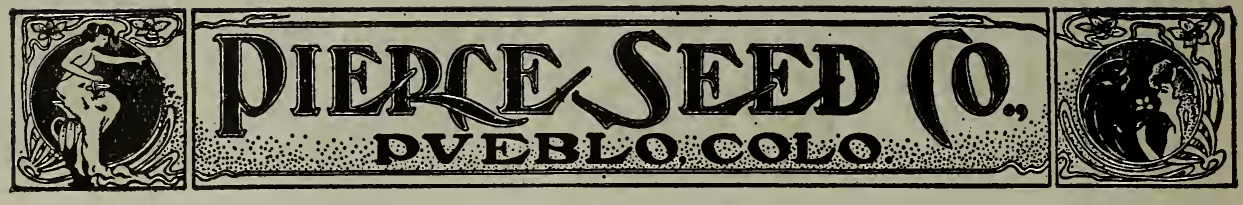

\section{Field Seeds}

\section{GRASS MTXTURE}

GRASS MIXTURE for low ground.-This mixture has given the best satisfaction; ground that could be pastured only in dry season, when sown with this mixture has been pastured year round, and also a good erop of hay has been cut. Good for seepage land above headgate dams. Market price.

\section{BROMUS INERIMIS.}

Bromus Inermis (Broome Grass), beardless. The introduction of this variety into the arid and semi-arid regions of the West and Northwest has given the people a pasture and meadow grass of great promise. This grass has been grown with success on the Dividie east of the mountains, and should be used by all that have a shortage of water for irrigation. Try a few pounds. Mlarket price.

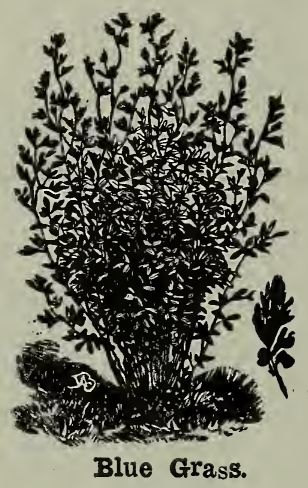

TIMOTHY.

Timothy is grown more extensively every year, and has proven to be one of the best crops for hay in the foothills that can be - sown. Sow twelve to twenty pounds to the acre. Market price.

\section{BLUE GRASS.}

Kentucky Blue Grass, fancy cleaned, used principally for lawns, and sown in the foothills for pasture it does remarkably'well. For lawns, use nne pound to 10 feet square; for pasture, about twenty-eight pounds to the acre. Market price.

\section{RED CLOVER.}

Red Clover is used more every year, and while not as productive as Alfalfa, it is sown by a great many in orchards. Twelve to fifteen pounds to the acre. Market price.

\section{WHITE DUTCH CLOVER.}

Used with Blue Grass for lawns, makes good sheep pasture, and is fine pasture for bees; must be sown where it will have plenty of moisture. Market pr:ce.

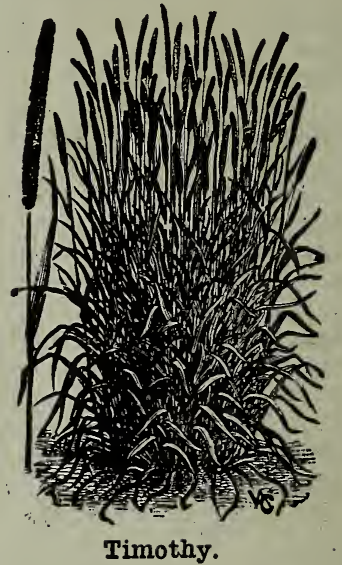

\section{ORCHARD GRASS.}

Extremely hardy. This is one of the earliest grasses to start in the spring and makes the very best pasture. Horses are very fond of this grass and when sown with alfalfa makes a very desirable hay for any kind of stock. This should be sown very extensively in the foot hills and it does exceedingly well with a small quantity of water. Sow about fifteen pounds to the acre. Market price.

\section{RED TOP.}

We carry both clean and fancy grades. Thrives best in low lands, making a very firm sod. Does well in Colorado, and is grown quite extensively in the foothills. Sow from eighteen to twenty pounds to the acre. Market price.

\section{DWARF ESSEX - RAPE}

\section{A Secondary and Catch Crop.}

Often fine rape may be grown upon land that has already produced a crop of some. of the early maturing cereals such as rye, oats or barley. It is used as a soiling crop or pasturage for sheep or swine. Market price.

Use Kentucky Blue Crass and White Clover for Lawns.

We Are Here to Stay; We Want Your Trade. 


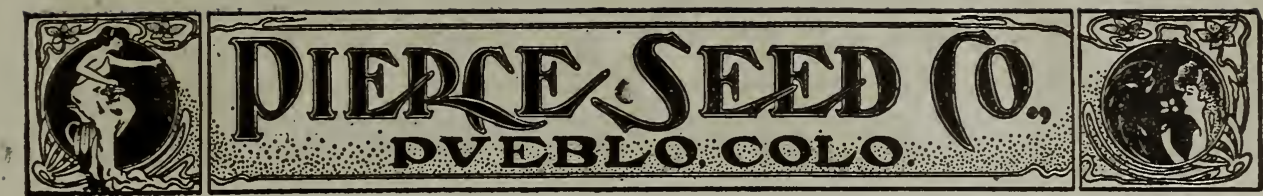

\section{Field Seeds}

(CONTINUED).

ALFALFA OR LUCERNE CLOVER.

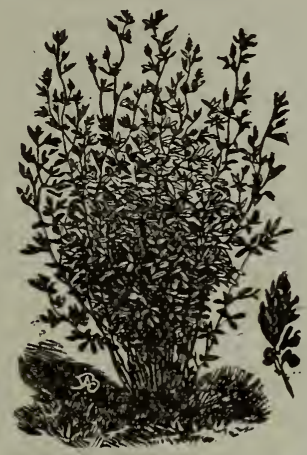

A valuable forage plant. It requires a rich, deep soil. The sun must have free access to Alfalfa, and the ground must be rolling to eriable the water to pass off readily. A wet underground is fatal to the plant. A great many sow in connection with oats. The latter should be sowed first and harrowed in, and then sow from fifteen to twenty pounds to the acre of alfalfa seed, and roll the ground well. It is best when eut in bloom. It will not shed rain like other hay, and must be either stored in sheds or covered with canvas. After being cut, alfalfa should lie until it wilts, and then cured in the cock, else the leaves become dry, crumble off, and the best part of the crop is lost. It is an all around feed for all kinds of stock. Alfalfa pasture is the best for all kinds of stock. Market price.

\section{BARIEY.}

HULLESS AND BEARDLESS.-It is very productive and does equally as well in high and low altitudes. The straw is of good length and strong, the head's look very much like wheat. This is not a brewing barley, but is used for feeding stock. Our seed is Colorado grown. Market price.

\section{WHEAT.}

WHEAT.-Regenerated Defiance.-A soft, white spring wheat, a Colorado production and one of the very best. Market price.

MACARONI OR DURUM (Kabanka) Spring Wheat.-Our seed is Colorado grown, without irrigation. This is the variety recommended by the Colorado Agricultural College for arid lands. We have a fine sample of this variety. Market price.

TURKEY RED.-(Winter).-The very best fall wheat for Colorado; . is ready sale for milling. Market price.
FIELD CORN.

(Colorado Grown).

WHITE AUSTRALIAN CORN.-It is an early flint corn, used by a great many for roasting ears. For those who have no water for irrigation, this is one of the best varieties. Very fine for hominy.

WHITE DENT.-This is a rery fine white corn and preferred by some to the Yellow Dent. Market price.

MILLER'S YELLOW DENT. - (Mountain Grown Seed).-This is a very productive coris, small ear and cob, more suitable to the foothills, and mountain districts, and thoroughly acclimated. Very early. Good for dry claims.

COLORADO YELLOW DENT.-This is Colorado grown seed. Well acclimated and a good cropper.

LONG YELLOW FLINT.-Very much like White Australian Corn except the color, a bright yellow. This is a new corn for Colorado and the seed we offer is Colorado grown. Market price.

WHITE DEN'C.-A large white dent corn. Colorado grown. Market price.

\section{WESTERN GROWN SEED.}

IOWA GOLD MINE.-Early Yellow Dent Market price.

IOWA SILVER MINE.-Early White Dent. Market price.

REED'S YELLOW DENT.-A large Yellow Dent. Market price.

IMPROVED LEAMING.-A large Yellow Dent. One of the best varieties for ensilage. Market price. 


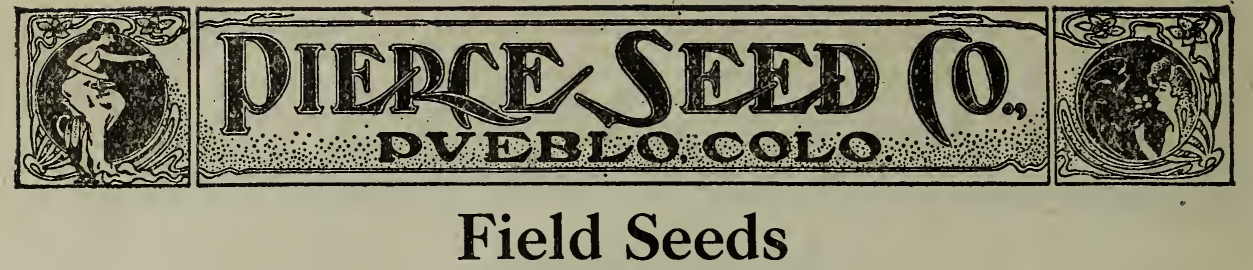

(CONTINUED.)

\section{GRIMM ALFALFA OR EVERIAASTING} CIOVER.

This is a variety of alfalfa that has been grown in Carver County, Minnesota, for over fifty years. Recent investigation has shown Grimm's Alfalfa to be one of the most hardy known, aside from extreme cold resistance, the Grimm is a heavy hay producer of fine quality, it is also a heavy seed yielder under favorable conditions. This variety has a large stooling and deep crowning habit which is characteristic of hardy strains. You should give this variety a trial. Is sown in drills, three to five pounds to acre, and cultivate between rows. Alfalfa grown in drills will not lodge near as much from wind or rain as when sown broadcast.

See picture of Grimm alfalfa on inside front cover and note the spreading habits of the roots and how thick it stools out above the ground. We have secured a small quantity of this seèd from a careful grower in Minnesota and can furnish it at $\$ 1.08$ per pound, if by mail, while this lot .lasts.

MILLET, Common.-This variety is grown extensively for hay and can be sown as late as first of July. It does not require irrigation if fair amount of moisture is in the ground. Common millet has a small slender head and fine straw. Market price.

MILISET, German.-This variety should be sown as soon after danger from frost is over and is best on good moist ground, and like other millet does not require irrigation if it has a fair amount of moisture. Market Price.

MILLET, Proso, sometimes it is called Manitoba or Hog Millet, and Broom Corn or Russian Millet. - This variety is grown more for the grain crop than Common or German. The stalks are coarse and woody, the heads are sprangling like Broom Corn and droop over. This variety is generally a sure erop in the dry arid region. Market price.
HOW TO MAKE A I.AWN.

In the early spring the ground should first be graded and covered about three inches with well rotted stable manure, plow or spade under from four to six inches deep, then the ground should bo well watered until the clods are all dissolved, and when in condition should be raked over level and smooth, sprinkle the ground well again and let lay until the soil is well settled. If not in too great a hurry it is a good plan to let the weeds start before sowing the seed. When ready to sow the seed the ground should be raked all one way and sow one pound of seed to 10 feet square, then rake the ground cross-ways and roll if possible. This then should be covered with a light coating of very fine and well rotted stable manure and kept moist by sprinkling as often as needed. A great many cover the ground after seed is sown with straw. This is a very desirable way if the lawn is made very late in spring. The better time in this locality to make and sow a lawn is in the month of June. The general rule is one pound of grass seed to 10 feet square, or if you care for clover, one pound of clover to four pounds of Blue Grass. This will insure a good thick sod the first season. It is useless to try and make a lawn on soil that has been excavated from cellar. Soil in Colorado must be airated from one to two years before seed will germinate or grow.

Clover being so much heavier than Blue Grass, seed should bo sown separate to get an even stand of clover.

We will deliver to your postoffice address, postpaid, the following vegetables and flower seeds in any quantity from 20 to 50 pounds, according to zone.

Asparagus, Table Beets, Brussels Sprouts, Cabbage, Cauliflower, Carrots, Celery, Chicory, Corn Salad, Cress, Cucumber, Endive, Egg Plant, Kohl Rabi, Leek, Lettuce, Me'ons, Mustard, Okra, Onions, Parsley, Parsnips, Peppers, Pumpkin, Radish, Rhubarb, Salsify, Squash, Tobacco, Tomatoes, Turnip, Ruta Baga, Herbs and Flower Seeds. 


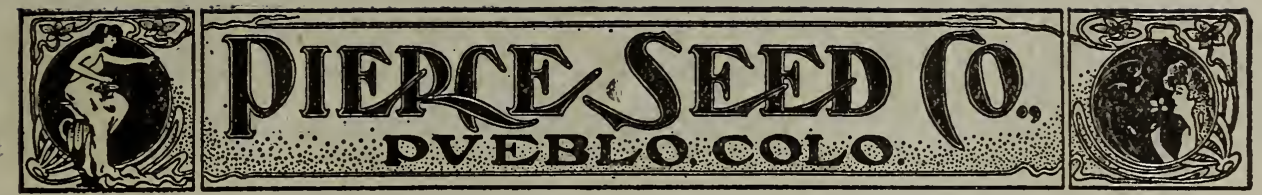

\section{Garden Tools and Cultivators}

\section{NEW MODEL SEED DRILL}

A very satisfactory drill that is complete in regulation of discharge, cut-off, marker, opening plow and cover roller. Price, $\$ 8.00$.

LITTLE WONDER SEEDER-Suitable for all grains and grasses. The construction is simple, strong and practical, easily carried with strap over the shoulder. A good but low priced seeder. Price, $\$ 1,25$ each.

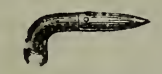

STEEL DIBBER

For setting out plants. 20c.

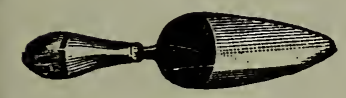

Garden Trowel.

Solid Steel, 50 cents.

\section{IMPROVED CAHOON HAND SEED SOWER-}

This is probably the most popular broadcast sower on the market. They have a force feed and throw the seed from 15 to 36 feet, according to weight.. Price, $\$ 3.50$.

ROTARY CORN PLANTER-Decidedly the best hand corn planter made, and a very desirable implement for those who have but a small field, or need to replant their ground. It puts the corn exactly where you want it and at a proper depth. It is easily worked and a most satisfactory tool in every way. It has three seed plates. Price, \$1.25.

BLACK HAWK CORN SHELLER-A sheller that, shells. Can be fastened to box or board. Very easily run and shells rapidly. Has automatic spring adjustment, adapting itself to all sizes of corn. Weight, about 20 pounds. Price, \$2.5 J.

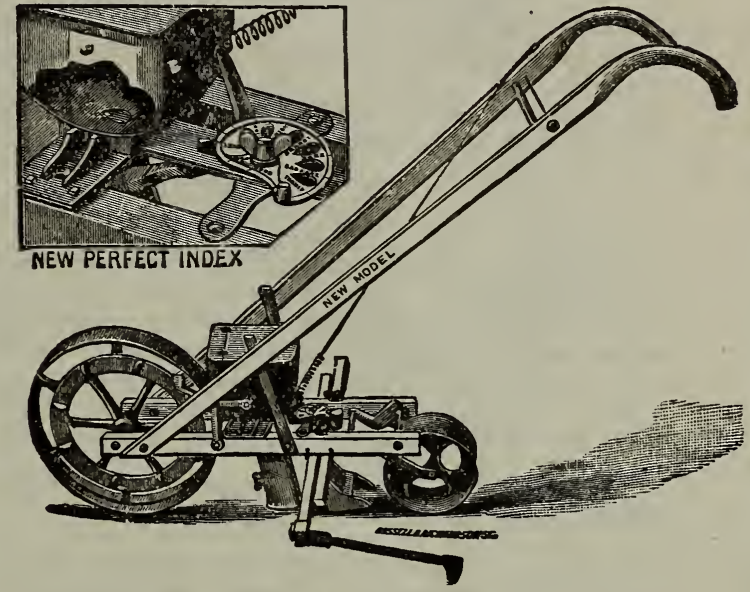

COW EASE, KEEPS OFF FLIES, GNATS, AND MOSQUITOS.

This liquid, when applied to cows in fly time, will keep them contented and they will maintain a steady flow of milk. Every dairyman and owner of live stock should use Cow Ease during the summer months. The best way to use Cow Ease is to apply with spray pumps. We have them suitable from 50ic to $\$ 1.00$ each.

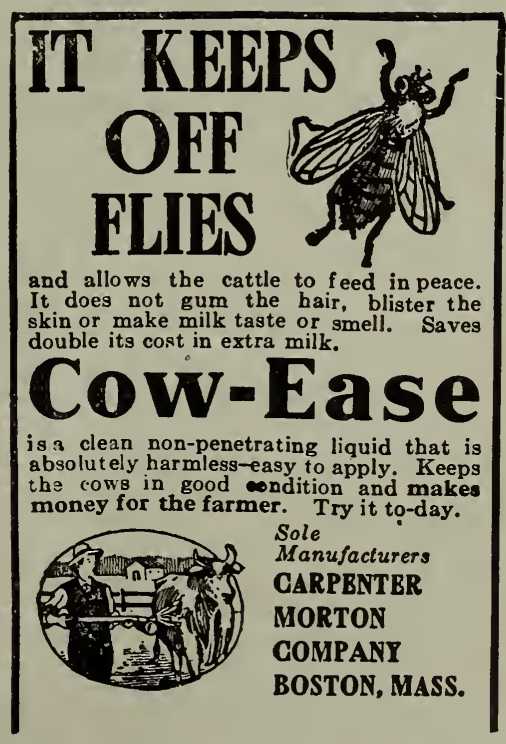

Price COW EASE, Gallon Cans, \$1.25: 1/2 Gal. Cans, 75c; Quart Cans, 45c. 


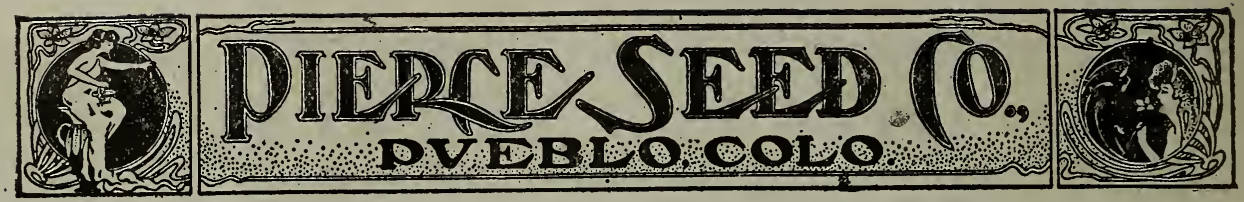

\section{Fertilizers}

\section{IAWN FERTILIZER}

To be used on the lawn in the spring and summer; gives immediate results; soluble; it does not disfigure the lawn like stable manure. One pound will cover about 10 feet square. Price, 50 lbs., $\$ 1.50 ; 100$ lbs., $\$ 2.50$.

\section{GARDEN TRUCK FERTILIZER.}

For garden truck and plants-none better. Use in hot beds or green house, and when cabbage, celery and other plants are set out in the open ground; use about one tablespoonful to each plant when setting out. Be sure to have fertilizer well mixed with soil. In hot bed and green house, use about one pound to a sash ( $3 \times 6$ feet). Price: 1 lb., 5c; 10 lbs., 40c; 50 lbs., \$1.25; 100 lbs., $\$ 2.00$.

NITRATE OF SODA.-A quick acting fertilizer. Mar'set price in 50-1b. lots, per 1b., 5 c.

BONORA, NATURE'S PLANT FOOD.-Bonora is good for all flowering plants, vegetables, strawberries, lawns, trees and shrubbery, producing a lasting and healthy growth. Bonora is used on the lawns of the Capitol grounds of Washington, D. C., also on other National grounds of same city. One teaspoonful in seven pints of water, one pound in 28 gallons of water. $1 / 4 \mathrm{lb}$. package, $25 \mathrm{c} ; 1 \mathrm{lb}$. package, 50c. If by mail add $16 \mathrm{c}$ per punod.

BONE MEAL.-Used extensively as a fertilizer for roses, grapes, vines and shrubs, palms and fierns. Price: 1 lb., 5c; 10 lbs., 35c.

\section{INSECTICIDES AND SPRAYS.}

ARISENATE OF LEAD.-This is an effective insecticide for leaf-eating insects, does not burn the leaves and foilage does not wash off by ordinary rains. Arsenate of lead is used on Colorado orchards more than any other insecticide, and with success. A number of our best Grape growers are now spraying their vines with Arsenate of lead.

$11 / 2$ to 2 pounds of lead to 50 gallons of water will do good work with the Spray pumps and fine nozzles that we handle.

Price: $5 \mathrm{lb}$. package, $\$ 1.00 ; 10 \mathrm{lb}$. package, $\$ 2.00 ; 25 \mathrm{lb}$. pacłage, $\$ 4.00 ; 50 \mathrm{lb}$. package, $\$ 6.00$; 100 lb. kegs; $\$ 10.00$.

EILUE VITROL.-Sulphate copper, blue stone in crystal ready to dissolve. One pound dissolved in gallon of water for 100 pounds wheat. Price: $1 \mathrm{lb} ., 10 \mathrm{c}$; 5 lbs., 50c; 10 lbs., 90c.

BORDEAUX MIXTURE, (Liquid).-Concentrated mixture to be diluted before using, prevents black rot, mildew and rust. 1 gal. cans, $\$ 1.25$.

CHLOROLEUM, (Liquid).-Will destroy ants, drives cockroaches away. 6 oz. bottle, $25 \mathrm{c}$; quart can, $60 \mathrm{c} ; 1 / 2$ gallon call, $85 \mathrm{c}$.
KEROSENE EMULSION, (Liquid).-For plant lice of any kind, scales or insects on trees. Ready for use by adding 25 to 50 parts of water to one pint of emulsion. Gallon, $\$ 1.00$.

FIR TREE OIL, (Liquid).-For red spider, slugs and all insects. $1 / 2$ pint cans, $40 \mathrm{c}$.

PARIS GREEN.-To be used in solution; $1 / 2$ pound to 60 gallons of water and 15 pounds lime for apples, pears and shade trees; 4 ounces Paris Green to 60 gallons water, 10 pounds lime for small fruits, cherries, peaches and apricots. This solution should be thoroughly strained before spraying. The Paris Green should be mixed into a paste of thickness of cream before putting in the lime water. The lime is necessary to prevent burning of leaves and also makes the Paris Green more soluble. To kill Grasshoppers: 100 pounds bran, 2 to 4 pounds of Paris Green, well mixed, moisten with enough sweetened water to moisten the bran, then scatter all over the field. $1 \mathrm{lb}$. package, $35 \mathrm{c} ; 3$ packages for $\$ 1.00$.

FORMALDEHYDE.-For the prevention of smut on grains. One pint diluted with 40 to 50 gallons of water is sufficient to treat 30 bushels of grain. $16 \mathrm{oz}$. bottle, $50 \mathrm{c}$.

PEERLESS GOPHER KILLER, Liquid, (Lee's). -A sure killer for Prairie Dogs, Gophers, Ground Squirrels and all burrowing animals. Qt. can, 75c.

PERSIAN INSECT POWDER.-This powder is used for all insects and flies, and used for a lice powder for poultry. $1 / 4$ lb., 20c; $1 / 2$ lb., 30c; $1 \mathrm{lb}$., EQc.

POISONED WHEAT.-For mice, prairie dog and gophers. We have prepared this for years and know that it will kill prairie dogs. 1lb., 20c; 10 lb. lots, $\$ 1.50$.

POWDERED HELLEBORE.-For worms on Currants and Gooseberries. $1 \mathrm{lb}$., $25 \mathrm{c}$.

SULPHO TOBACCO SOAP.-This is a cheap and effective insecticide on p:ants, flowers and shrubs and is popular, being put up in handy and convenient packages, clean and harmless; 3 oz. cakes makes $1 \frac{1}{2}$ gallons of prepared solution; 8 oz. cake makes 4 gallons solution. $3 \mathrm{oz}$. cake, $10 \mathrm{c}$, by mail, $13 \mathrm{c} ; 8$ oz. cake, 20c, by mail, $28 \mathrm{c}$.

SLUG SHOT. (Hammond's)-For worms on vegetables and flowering plants, used extensively on growing cabbage. 5 lb. package, 40c; $10 \mathrm{lb}$. package, 7 Ec.

TO-BAK-INE (Liquid).-A specially prepared concentrated solution of pure Nicotine, making it the most powerful insecticide and parasiticide known, and in most convenient form; will not injure, scent or discolor the most delicate flowers, foliage or vegetable. Kills green and black fly, mealy bug, red spider, thirp on plants, trees and vegetables. Price: $1 / 2$ pint can, $\$ 1.25 ; 1$ pint, $\$ 2.50$.

FISH OIL SOAP.-Used where insect life exists. Dissolve 2 ounces of soap to 1 gallon of water. Per 1b., $15 c$. 


\section{Poultry Supplies and Foods}

\section{MIDLAND POULTRY FOOD.}

We have our Midland Poultry Food put up in 100 pound sacks.

We are agents for Southern Colorado.

With Midland Poultry Foods you can raise your young chicks, fatten them for market and make your hens lay. It pays to feed Midland Food. Try it.

No. 1 for Nursery Chicks. 100 lbs., \$2.50.

No. 2 for Growing Chicks. 100 lbs., $\$ 2.50$.

No. 3 Fattening Chick Food. 100 lbs., \$2.50.

No. 4 Egg and Feather Producing Food. 100 lbs., $\$ 2.50$.

No. 5 Nursery Duckling Food. 100 lbs., \$2.50.

No. 6 Growing Duckling Food. 100 lbs., \$2.50.

HOYT'S MIXTURE.-For baby ehicks when first hatched. This is a well balanced dry food for young chicks and can be fed until chicks are six weeks or two months old. We prepare this food ourselves and know that only clean, sweet grains are used. We sold tons and tons of this food last season and are preparing for a large increased demand this coming spring. Feed our Hoyt's mixture and raise healthy chicks. A dry food for little chicks is very convenient to handle. Put up in 50 and 100-pound bags for shipping. $6 \mathrm{lbs}$. for 25c; $50 \mathrm{lb}$. bag, $\$ 1.25 ; 100 \mathrm{lb}$. bag, \$2.50.

MIXED GRAIN FOR LAYING HENS.-This consists of small grains, the right proportion of chareoal and other ingredients to make hens lay, and keep them in good, healthy condition. It pays others to feed our mixed grain for laying hens and will pay you. We have a good trade among ranchmen for this feed. Put up in 100 pound sacks at Market price.

BLOOD MEAL.-Conceded to be one of the greatest egg producers on earth. Stimulates egg production, is good for growing chicks, a good food for weak legged chickens. One tablespoonful a day fed in a mash for one dozen hens will give you surprising results. $1 \mathrm{lb} ., 10 \mathrm{c} ; 3 \mathrm{lbs}$. for 25c.; Special price in $100 \mathrm{lb}$. lots.

GREEN CUT MEAT AND BONE, (Dried).This is a product that we sell in large quantities. This food has all the elements to make a healthy growth. The meat is sufficiently evaporated to prevent becoming rancid. Keeps well.. Best fed in a mash two or three times a week. About one tablespoonful to a fowl. $8 \mathrm{lbs}$., 25c; $100 \mathrm{lb}$. bags, $\$ 250$.

MEAT MEAL.-A highly concentrated food A high per cent of protein. Use in wet and dry mash. $10 \mathrm{lbs}$., 50c; $100 \mathrm{lb}$. bag, $\$ 3.00$.

GRANULATED BONE.-This is a coarse ground green bone. Good for building up the frame of chickens and rich in phosphate of lime for shell production. This should be fed in a hopper or box where chickens can help themselves at all times. 8 lbs., 25c; 100 lbs., $\$ 2.50$.

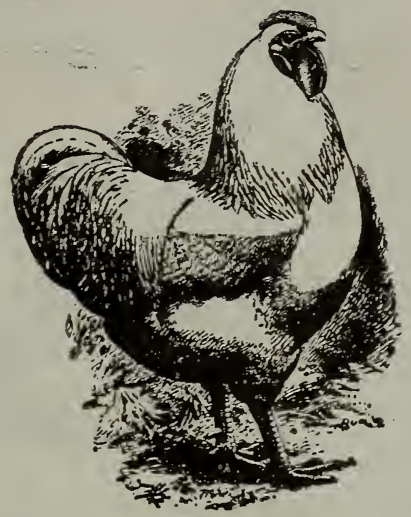

GROUND OIL CAKE.-It is the greatest flesh former and cream producer in use. Fed in dry or wet mash. 1 part oil cake meal to 5 partts bran. Fed twice a week is very beneficial, $8 \mathrm{lbs}$. for 25c. Marizet price in $100 \mathrm{lb}$. lots or more.

MILLET SEED.-Is one of the best grains for a scratch feed, then it is also good for young chicks. $8 \mathrm{lbs}$. for $25 \mathrm{c}$.

HIGH PROTEIN BEEF SCRAPS.-A superior grade or meat scraps prepared in a meal for feed. ing in mash or with other soft foods. $6 \mathrm{lbs}$., 25c; 50 lbs., \$2.25; $100 \mathrm{lbs}$., $\$ 4.00$.

ALFALFA CLOVER MEAL.-The alfalfa meal that we offer for poultry food is the third cutting. Alfalfa meal is the most satisfactory green food for chickens that we handle. Seald the alfalfa meal and add bran to make a mash. There is no better feed. 50 lbs., $75 \mathrm{c}$; $100 \mathrm{lbs}$., $\$ 1.50$.

CHARCOAL. - Is one of the most necessary foods there is for all kinds of fowls. Pure-charcoal is an excellent aid in arresting bowel complaints, and should be in hopper before the fowls all the time. Coarse granulated for grown fowls, fine granulated for chicks. Per lb., 5c; 50 lb. sack, $\$ 1.50$.

GRAY GRANITE GRIT-Coarse and fine. Poultry that is confined must have grit furnished and Gray Granite is the best. It is sharp and does the work. $12 \mathrm{lbs} ., 25 \mathrm{c}$; $50 \mathrm{lbs}$., $75 \mathrm{c}$.

OYSTER SHELL, ground coarse or fine-This is one food that should be in every poultry yard. convenient and handy where fowls can help them selves at all times. It is necessary for laying hens. $10 \mathrm{lbs}$., 25c; $100 \mathrm{lb}$. sack, $\$ 1.25$.

CHLOROLEUM LIQUID. - Non-poisonous disinfectant and antiseptic. One of the best sprays for chicken houses. kills lice and mites. For a disin. fectant lice killer and animal dip it is economical and easy to apply. For general spraying purposes, 3 to 4 tablespoonfuls to a quart of water. 6 oz. bottle, $25 \mathrm{c}$; pt. can, $40 \mathrm{c}$; quart can, $60 \mathrm{c} ; 1 / 2$ gal. can, 85c. Full directions on each can. 


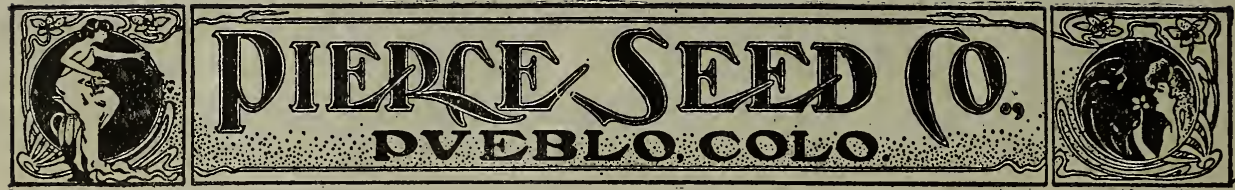

\section{Poultry Supplies and Foods}

G. F. CONKEY CO. POULTRY GOODS.

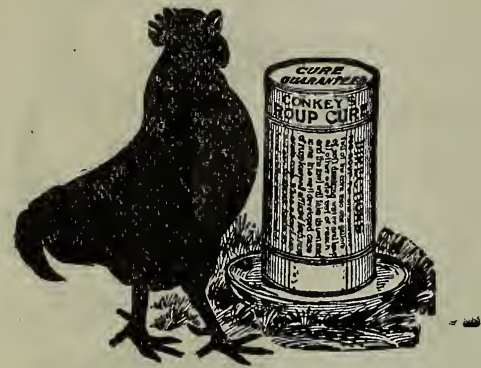

CONKEY'S ROUP REMEDY.-25c, 50c, and $\$ 1.00$ pkgs.

CONKEY'S CHOLERA REMEDY.—25c pkgs.

CONKEY'S LAYING TONIC.-11/2 lb. pkgs., 25 c.

CONKEY'S BRONCHITIS REMEDY.-50c pkgs.

CONKEY'S HEADLICE OINTIMIENT.-Per pkg., $25 c$.

CONKEY'S LICE POWDER.-15 0z. pkg., 25c; trial p'sg., 10c.

CONKEY'S LICE KILLER.-Quart cans, 35c; 2 quart cans, $60 \mathrm{c} ; 1$ gallon, $\$ 1.00$.

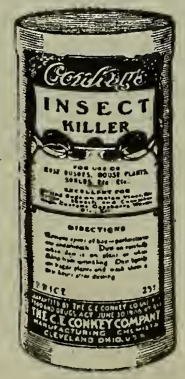

CONKEY'S INSECT KILLER kills all insects on plants, squash, cucumber, melon and other bugs on vines.

\section{ELECTRIC COMPOUND.}

Only self applying in the world for killing lice and mites on your poultry. Price, $\$ 1.00,50 \mathrm{c}$. and $25 c$.
PRATT FOOD COMPANY GOODS.

PRATT'S POULTRY REGULATOR-26 oz. pkg., 25c.

PRATT'S POULTRY REGULATOR-4 lb. pkg.50c

PRATT'S POULTRY REGULATOR—9 lb. pkg., $\$ 1.00$.

PRATT'S ROUP CURE-Per box, 25c.

PRATT'S LICE KILLER POWDER-Per box., 10c.

PRATT'S LICE KILLER POWDER-Per box, 25c

GEO. H. LEE COMPANY GOODS.

LEE'S LICE KILLER-1 quart cans, 35c.

LEE'S LICE KILILER-1/2 gal. can, 60c.

LEE'S LICE KILLER-1 gal. cans, \$1.00.

LEE'S EGG MAKER-21/2 lb. pkgs., 25c.

LEE'S EGG; MAKER—51/2 lb. pkg., 50c.

LEE'S EGG' MAKER-25 lb, pail, $\$ 2.00$.

LEE'S GERMOZONE-Per bottle, 12 oz., 50c.

IEEE'S GERMAZONE - 60 tablets per box by mail, 50c.

LEE'S INSECT POWDER-Per box, 25c; prepaid, $40 \mathrm{c}$.

LEE'S HEADLIOE OINTMENT-Per box, $15 \mathrm{c}$.

LEE'S FLYO CURO (A Liquid)-Will drive away flies and other annoying insects. Price per quart can, 35c.

SPRAY PUMPS-To apply Lee's Lice Killer and Flyo Curo, 50c each.

OPAL NEST EGGGL-These are used in nests to save eggs from freezing, and are very convenient to have in each nest. Per dozen, 25c.

MEDICATED NEST EGGS-The greatest discovery for ridding poultry of vermin, the least trouble to use, only place the eggs in the nest. 5c each; 50c per doz.; if by mail, 60c. 


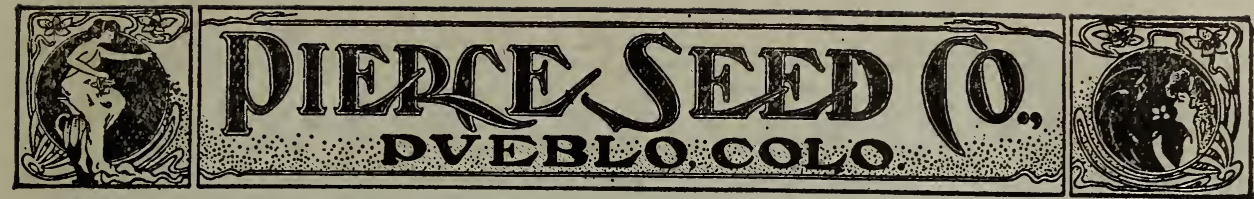

\section{Davis' Anti-Louse Roost Bracket}

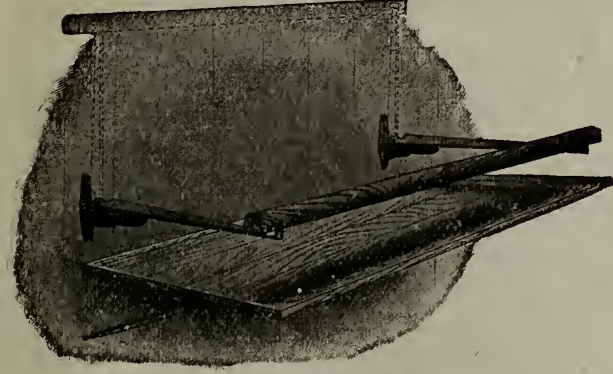

No. 1, Single Roost Style.

Price, per pair .................. \$.75 Price, three pairs $\ldots \ldots \ldots \ldots \ldots . \ldots \ldots 2.00$

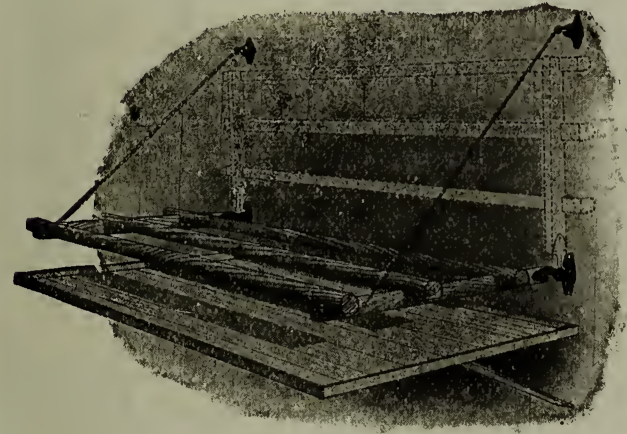

No. 2, Multiple Roost Style

Price, per pair .................. $\$ 1.25$

Price, per three pairs .............. 3.25

Not an ordinary, cheaply made affair, but substantially made. For single perch roosts use two brackets for perches up to six feet long.

Will effectually protect you ${ }^{\boldsymbol{r}}$ frols from midge louse or mites ravage by making it impossible for them to reach the fowls at night. Each point of contact between the roosts and building is provided with oil cups and the mites cannot get onto the roosts from the building, or vice versa. In addition to this, they are the most convenient bracket on the market. The roosts can be raised up out of the way for cleaning the dropping board, or they can be taken ont of the building by merely drawing out the pins with which the brackets are put together.

LEG BANDS FOR CHICKENS, TURKEYS, PIGEONS AND ALL KINDS OF FOWLS.

Climax, double clinch, flat aluminum, per doz., postpaid .................. 15c The convenient leg bands, per doz.,......20 Pigeon, seamless and double clinch, per doz. postpaid ....................15c
Davis' Pure Food and Water Fountain

You are taking long chances to save a quarter if you do not use Davis Food and Water Fountain.

Fact 1. It is the only fountain on the market which can be satisfactorily used for either water or grain, grit, oyster shells etc.

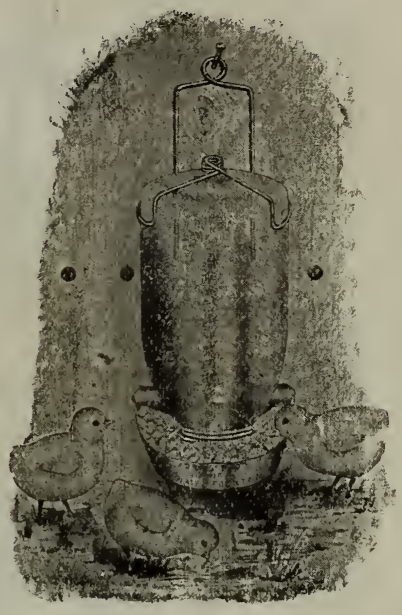

Fact 2. It is the ouly fountain which is adapted to hold any ordinary glass cottly o: eil in as a water retainer.

Fact 3. It is the most satisfactory fountain on the market for little chicks. It is hung up and cannot get tipped over or flled with dirt as do fountains arranged to be set on the floor, and chicks cannot get drowned in it.

Fact 4. It *keeps the water clean, sweet and cool.

Fact 5. It can be emptied and refilled in an instant without removing bottle or can from the holder. Merely invert and slip out of bottle or can to one side as shown in cut, fill, replace, and turn fountain to upright position again.

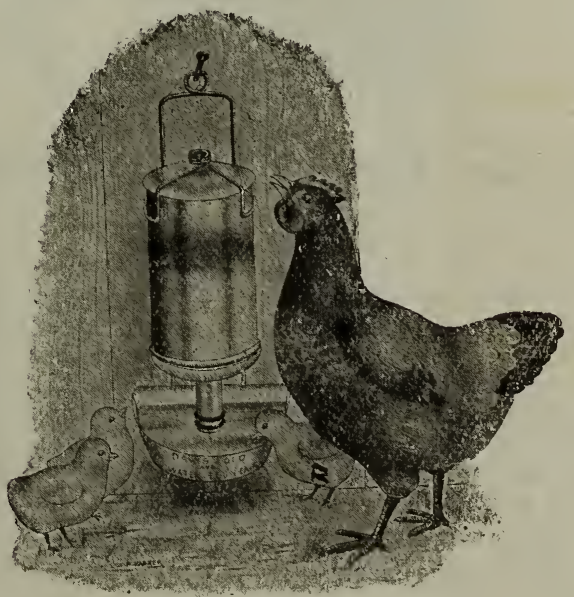

Price, each 25c; postage 15c. 


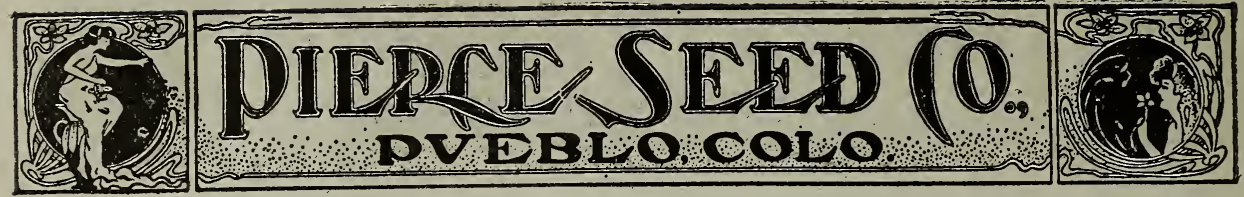

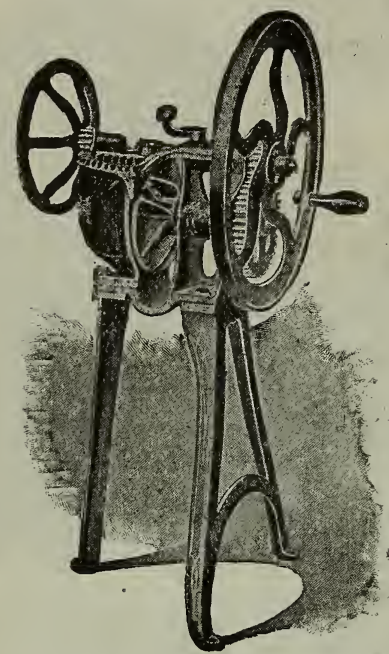

THE HUMPHREY OPEN HOPPER GREEN BONE AND VEGETABLE CUTTER.

No. 1, Hand Power, $\$ 13.00$.

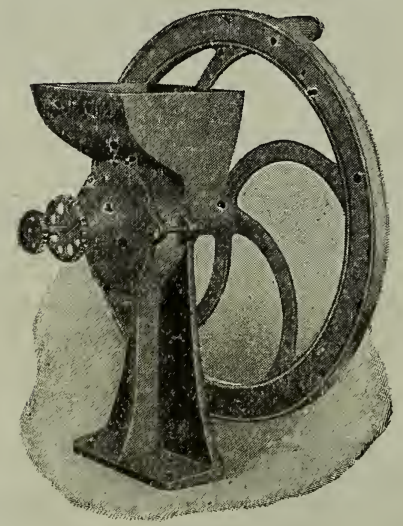

\section{No. 32 Hand Grinding Mill}

In this mill are embodied all the good features of other hand grinding mills to which have been added universal burrs or grinding plates that are adjustable for grinding coarse or fine. This machine grinds oats, barley, rye, corn, peas, dry bone, oyster shells, nut shells, dry stale bread, etc., for poultry feed, or will grind table meal for family use; has a 16-inch fly wheel and is light running.

The capacity of this mill is not equalled by any other of the same size.

Shipping weight, 40 lbs.

Capacity, 1 to 2 bushels per hour..

Price, \$4.00, F. O. B. Pueblo.

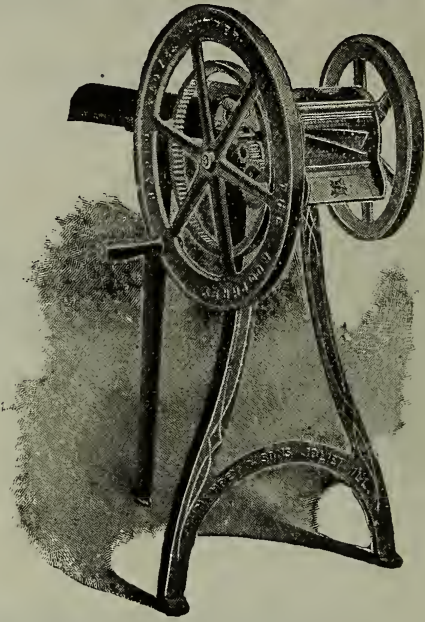

THE HUIMPHREY RAPID CLOVER AND ALFALFA CUTTER.

A heavy, well finished machine to cut clover and alfalfa into pieces $1 / 8$ inch and less. Stand Clover Cutter. (Weight 105 pounds) $\$ 11.00$.

\section{International Sanitary Hover}

It is entirely circular and has no corners for the chicks to crowd into. It is so constructed that it is warmest near the curtain. This causes the chicks to distribute themselves around the edge of the curtain where they have plenty of room and fresh air, as well as warmth. The lamp can be lifted out through the top by a person standing up

PRICE, $\$ 8.50$.

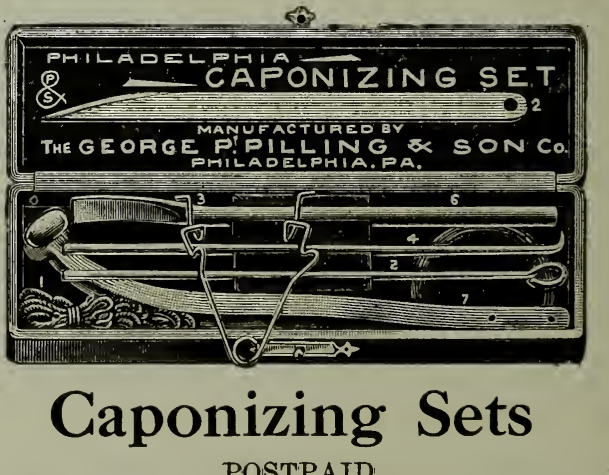

POSTPAID.

Philadelphia Capon Slet $\ldots \ldots \ldots \ldots \ldots \ldots \$ 2.50$

Philadelphia Capon Set, in case ......... 2.75

Pillings Farmer Capon Set ............ 3.00 


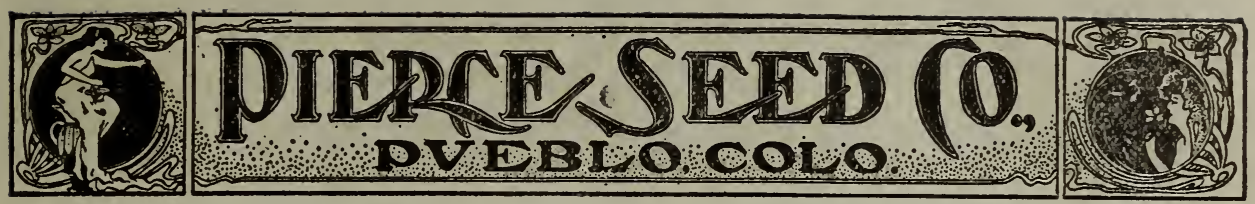

\section{Incubators and Brooders}

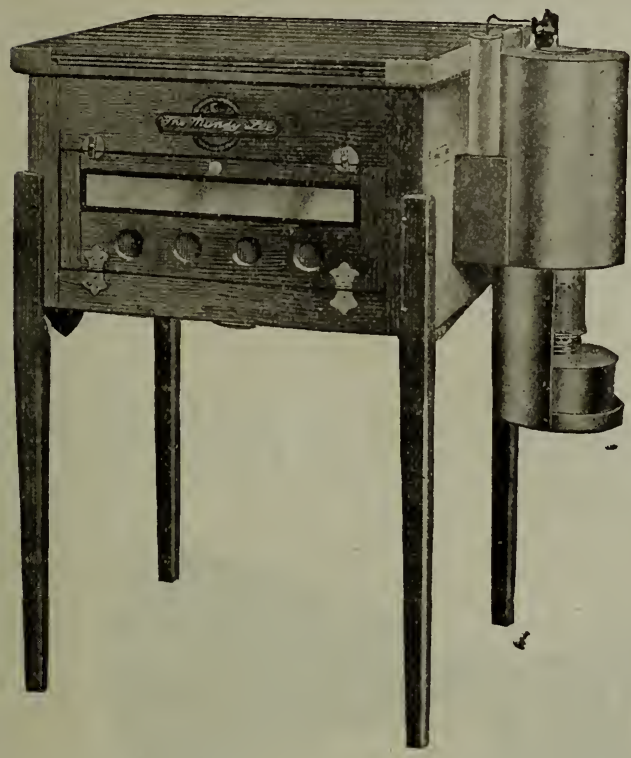

THE MANDY LEE.

60 Egg Size ................... \$10.00

100 Egg Size ................. 18.00

140 Egg Size .................... 22.00

200 Egg Size ..................... 27.00

Send for descriptive catalogue.

\section{MANDY LEE BROODERS.}

Regular, 100 to 150 chicks .......... $\$ 13.00$

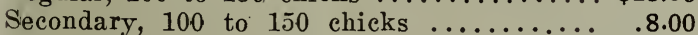
Fireless No. 8, 100 chicks ............ 5.00 Fireless No. 10, 200 chicks ............. 8.00 BUCKEYE INCUBATORS.- 50 Egg size.. $\$ 8.00$ 51 chicks from 50 eggs. If interested, send for circular telling how it was done.

\section{"TYCOS", ELECTRIC LIGHTED INCUBATOR THERMOMETER.}

The difficulty of reading a thermometer in the darkness of an incubator is now solved. The above device may be furnished with any "Tycos" Incubator Thermometer. The light is reflected onto the scale itself, brilliantly illuminating the figures and showing sharply the end of the mercury column. The attachment is movable, so that it may be adjusted to light up any part of the scale which may be desired.

Outfit, complete, with Battery, wire, etc., and choice of any regular 75e "Tycos", Incubator Thermometer, Each, \$2.50.

\section{Thermometers}

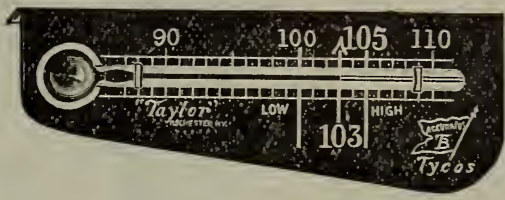

\section{"TYCOS", CERTIFIED INCUBATOR THERIMOMETERS}

With scale etched on the glass tube so that should the tube from any cause work loose on the mounting, the efficiency of the thermometer would not in any manner be diminished. Made in mercury tubes only. Each, \$1.50; two for $\$ 2.50$.

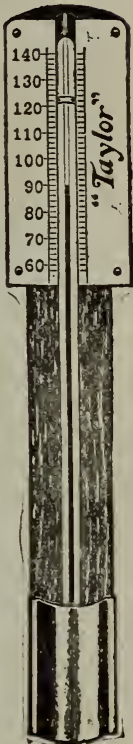

INCUBATOR THERMOMETERS, “ TYCOS”'Arljustable, to most any thermometer; Each, $75^{\circ}$. postpaid.

BROODER THERMOIMETERS.-25c to $75 \mathrm{c}$ each postpaid.

DAIRY THERMOMETERS.-Each 25c, postpaid. DAIRY THERMOMETERS.-Floating, Each, 75c, postpaid.

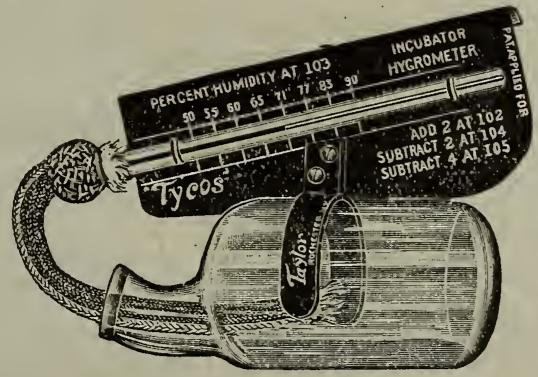

THE "TYCOS", INCUBATOR HYGROMETER.

Millions of chicks die in the shell every year for the want of proper mojsture conditions. The "Tycos" Incubator Hygrometer is not a regulator of moisture, but an indicator of conditions, so that if not correct, they may be made so.

The illustration shows the correct position of the instrument in use, taking the place of one egg in the tray, thus showing the conditions actually surrounding the eggs.

The use of the "Tycos" Incubator Hygrometer effe-tively lessens the percentage of chicks dying in the shell-due largely to improper moisture con. ditions.

"Tyeos ", Incubator Hygrometer, each, \$1.50; extra wicks, per dozen, $\$ 1.00$ r each, $10 \mathrm{c}$. 


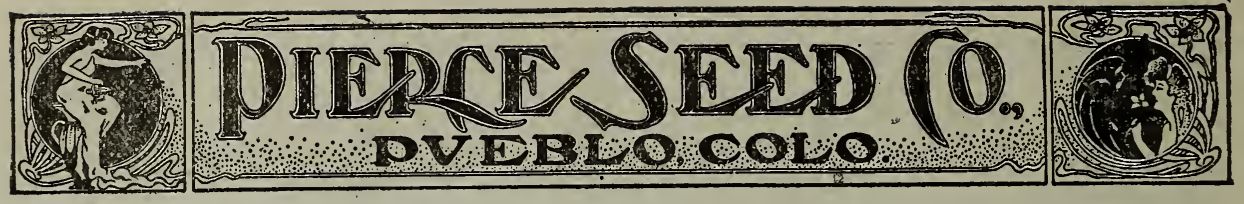

NEW NO. 29 LIGHTNING ALI BRASS SPRAY PUIMP. - A white wash spray pump -This pump is made entirely of brass, with the exception of the hand le and stirrup, which are made of mallable iron. Has biass valves, brass plunger, fitted with 3 feet rubber hose with coupling connection to pump, 2 interchangeable brass nozzles, one giving a mist-like spray. This pump can b e taken a part and cleaned, making it one of the best spraying pumps for applying $w$ hit ewas h. Price, each, $\$ 3.50$.

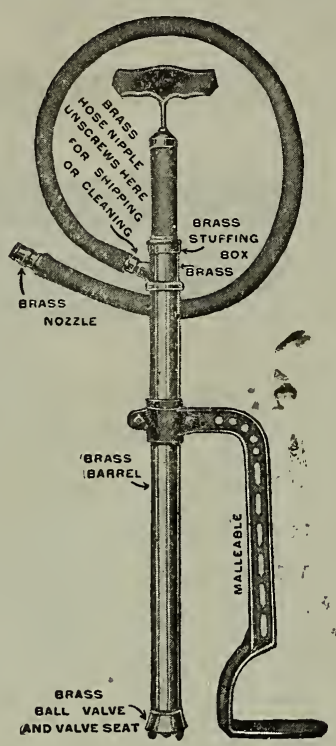

Mushrooms

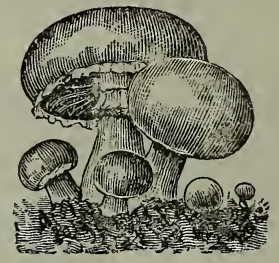

MUSHROOM SPAWN-Per brick, 25c, postpaid. $40 \mathrm{c}$.

REMEMBER-Transportation charges from $\mathrm{Pu}$ eblo Freight Depot and Express Office must be paid by purchaser unless otherwise noted in this catalogue.

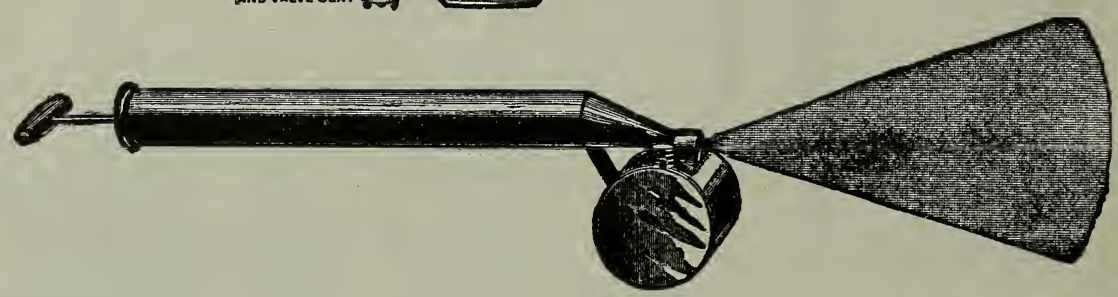

This pump is filled from the top of can through a screw cap opening. Is a very handy and convenient spray pump. Price, 50c

\section{Numerous Items that We Can Furnish}

SPRATT'S DOG BISCUIT.-A complete food for grown dogs. $10 \mathrm{c}$ per pound.

SPRATT'S PUPPY CAKES.- A puppy food that is relished by growing pups and small dogs. 10c per pound.

SPRATT'S DOG SOAP-25c per cake.

GRAFTING WAX (Lyon Brand)-For budding and grafting, used also on bruised and barked trees and shrubs. Furnished in cakes ready fo. use. 1 lb. cake, 35c; 1/2 lb. cake, 20c. Postage extra.

CHICKEN PUNCH MARKERS (Acme)-By mail, $25 \mathrm{c}$ each.

GRIT MORTAR-For breaking up dishes and rock for poultry grit. 9 inches in diameter and 11 inches high with removable perforated bottom. Weight 40 pounds. Price, $\$ 3.00$.

NORWICH AUTOMATIC CHICKEN FEEDERThis is one of the best and most convenient feeders for grain out. Will save its cost in a short time by not feeding your neighbors' pigeons or the flocks of sparrows that now get a great portion of feed on the ground. No. $1 \$ 2.75$;
No. 2, \$3.50. Send for cjrculars. We are State Agents for the NORWICH AUTOMATIC FEED ERS.

EYRIE EGG BOX CARRIERS-For setting of eggs to ship. Holds 15 eggs. Price, each, 15c.

EGG CARTON-Holding one dozen eggs; used for ș́pecial delivery of fresh eggs. 15c per dozen; $\$ 1.00$ per 100 , postpaid.

THE HEN FRIEND DRINKING FOUNTAIN AND FEEDER-Made to resist frost and not leak. No. 1, 60c; No. 2, 40c; No. 3, 30c.

SANITARY GRIT AND SHELL BOX-Three compartments, made of galvanized iron. Price, $75 \mathrm{c}$. NATURAL FISH FOOD-Per box. 10c. postpaid. FISIH FOOD (WAFER) - Per pkg. 5c, postpaid. SEAIMILESS SACKS (AMERICAN A)-Market Price.

MOCIKING BIRD FOOD-Per can, 35c.

EXHIBITION COOPS-Knocked down. Pen size, $\$ 2.25 ;$ Trio size, $\$ 1.75$

CATNIP BALLS-A plaything for cats and kittens. 15c each; postpaid 20c. 


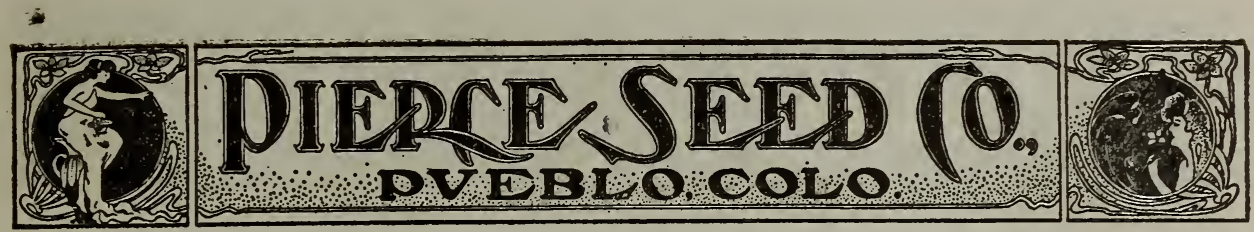

\section{SAL-VET}

Sal-Vet,is a salt, medicated sciontifically. It contains a number of tried, effiective, medical ingredients, which animals in their natural state are prompted to seek.

Worms and indigestion are responsible for about 90 per cent of live stock losses - annually amounting to millions of dollars. U. S. G̛overnment reports prove this. These losses can be overcome or prevented.

If interested, send for circular giving full directions. Sold only in original packages.

10 lb. package ................. \$ .75

20 lb. package .................. 1.25

40 lb. $k e g \quad \ldots \ldots \ldots \ldots \ldots \ldots \ldots \ldots \ldots \ldots \ldots \ldots \ldots \ldots .25$

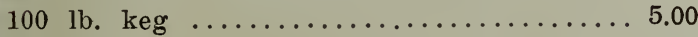

Special price and terms in large quantities.

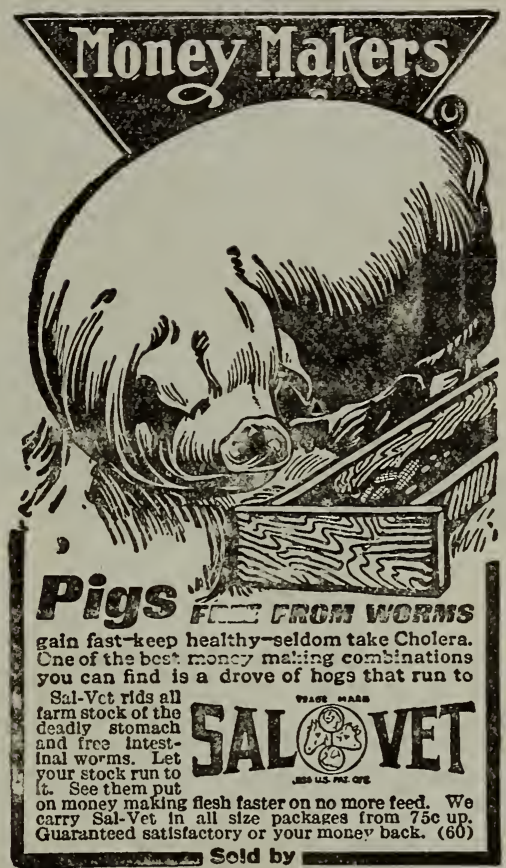

\section{BLATCHFORD'S CALF MEAL Don't Feed Butter Fats to Your Calves}

\section{IT IS WORTH MORE FOR OTHER PURPOSES.}

1st. Will raise three or four calves at the cost of one where milk is fed.

2nd. You can raise your own best milkers, thereby increasing the yield of milk.

3rd. You can veal your calves quickly and economically.

4th. It is very little or no extra trouble to use.

5th. The profits are large. The only cost comes at the start.

6th. It is the Best Calf Meal at any price.

100 POUNDS MAKES 100 GALLONS OF PERFECT MIIK SUBSTITUTE

\section{HOW TO RAISE CALVES CHEAPLY AND SUCCESSFULLY WITHOUT MILK}

\section{0 lb. Bags, - $\$ 3.60$ \\ 50 lb. Bags, - $\$ 1.80$ \\ 25 lb. Bags, - $\$ 1.00$ SEND FOR CIRCULAP CONTAINING FULI DIRECTIONS AND TESTTTMONIALS}

DE LAVAL SEPARATOR_Best cream separator now in use; more of these separators in the Arkan sas Valley than any other make. Write us for eireular and prices.

BANNER ROOT CUTTER FOR POULTRY AND sTOCK - Cuts Beets, Carrots, and all vegetables and roots. Hand Power, $\$ 5.00$.

WE CARRY PRATT'S, LEE'S AND INTERNATIONAL STOCK FOODS.

THIS IS AN ITEM-We make no charge for delivery to the Express Office or Railroad Depots. 

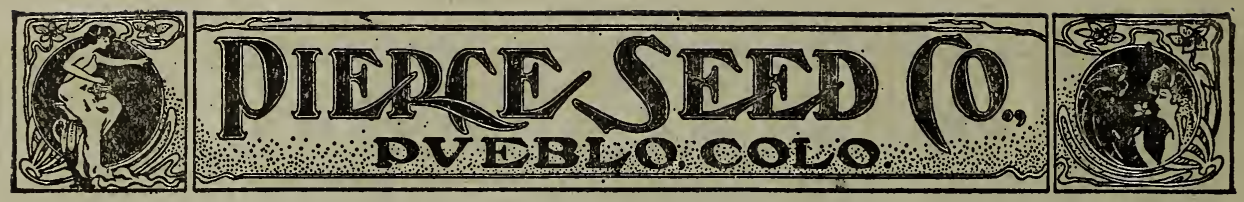

\section{THE DOVE-TAILED HIVE}

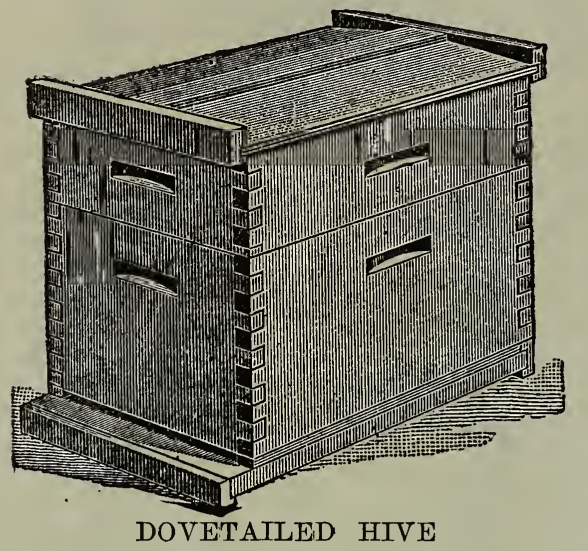

The standard hive, eight frame and $1 \frac{1}{2}$ stories. The body consists of a plain box, $18 \frac{1}{4}$ inches long, $121 / 8$ inches wide and $9 \frac{1}{2}$ inches inside measure, made of $\pi / 8$ lumber and dovetailed at the corners. it has eight self-spacing Hoffman brood frames, metal rabbits and division board.

The super consists of a box, onel half as deep as the hive, which have for their bottom pattern slats, ut the same size and shape as the sections; wood separator and nails go with this hive.

'rice:

3 frame, $11 / 2$ story, each ............. \$2.25

$\$$ frame, $1 \frac{1}{2}$ story, 5 hives $\ldots \ldots \ldots \ldots \ldots . . \ldots 10.50$

Hives are put up five in a crate, and weigh about 140 pounds per crate.

Above prices knocked down.

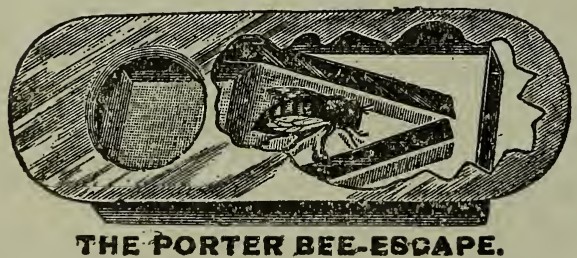

Price, 20c each; \$2.25 per dozen, postpaid.

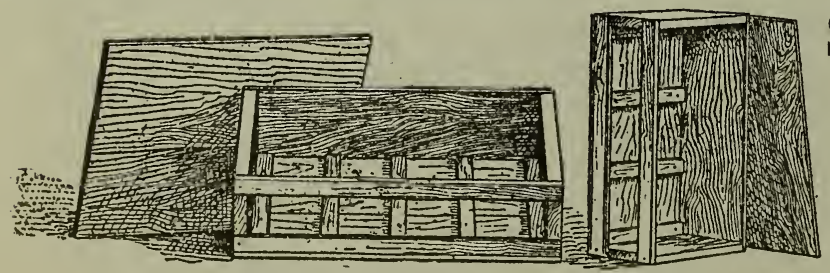

\section{SECTIONS}

$4 \frac{1}{4} \times 4 \frac{1}{4} \times 17 / 8$ are the standard section.

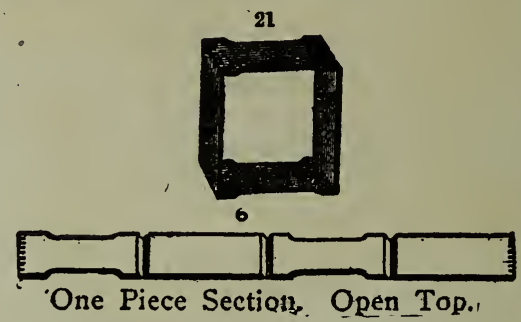

The No. 1 section is made from only the whitest basswood.

In lots of $100-$ No. $1 \ldots \ldots \ldots \ldots \ldots \ldots .75$

In lots of $500-$ No. $1 \ldots \ldots \ldots \ldots \ldots . .00$

In lots of $1,000-$ No. $1 \ldots \ldots \ldots \ldots \ldots .75$

In lots cf $1,000-\mathrm{No} .2 \ldots \ldots \ldots \ldots \ldots . \ldots \ldots$

Sections are put up 500 in a crate, and weigh about 60 pounds per 1,000 .

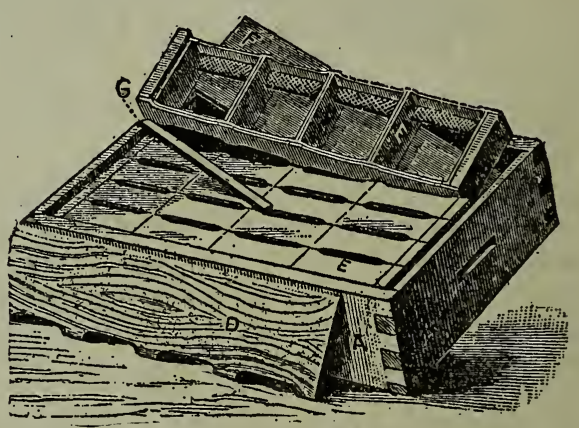

Extra Supers for 8-frame Hive. Pattern Slats.

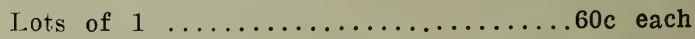
Lots of $5 \quad \ldots \ldots \ldots \ldots \ldots \ldots \ldots \ldots \ldots \ldots \ldots \ldots \ldots$

In lots of $10 \ldots \ldots \ldots \ldots \ldots \ldots 2.25$

In lots of $50 \ldots \ldots \ldots \ldots \ldots \ldots \ldots \ldots \ldots \ldots \ldots$

24 lb. single tier with g!ass, nails and paper complete in original cases of 50 per case. 


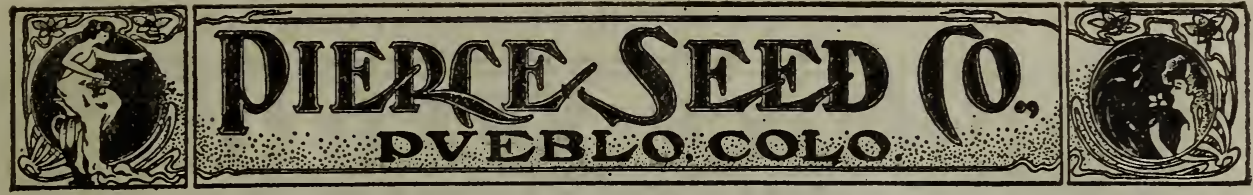

\section{BEE FIXTURES}

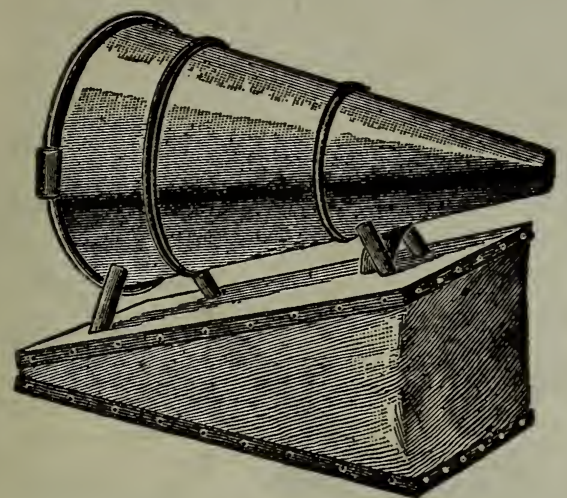

THE CLARK SMOKER

This is a cold blast smoker; it is well made, of good size, cheap and serviceable. Price, 60c.

\section{CORNEIL SMOKER}

Price, $\$ 1.00$ By mail add $20 \mathrm{c}$ each for all smokers.

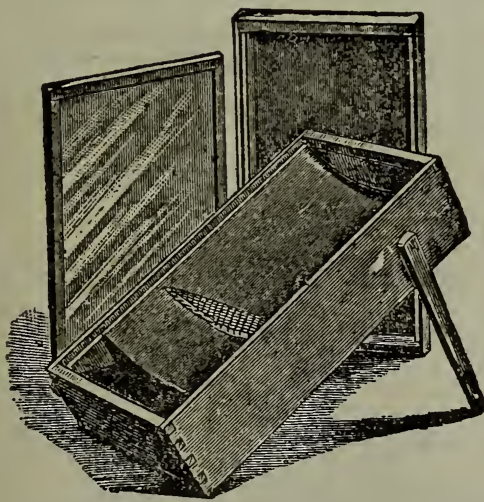

\section{DOOLITTLE'S SOLAR WAX EXTRACTOR}

Better than all artificial heat devices is a Solar IIax Extractor. A good one will more than pay for it:elf in ore season. Price, each, $\$ 4.75$.

Per 100

Hoffman Brood Frames ............... \$3.50

Section Holders ..................... 2.50

Wood Separators for $4 \frac{1}{4}$ sections $\ldots \ldots \ldots \ldots 1.00$

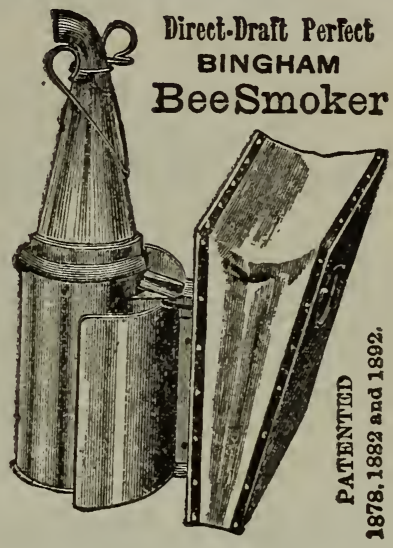

BINGHAAC SMOKERS

Three-inch barrel .................\$1.00

PARKER'S MACHINE FOR FASTFNING STARTERS IN SECTION BOXES

With a little practice, the machines can be made to work very satisfactarily. Price $25 \mathrm{c}$ for our $4 \frac{1 / 4}{4}$ $x 41 / 4$ sections. By mail, $40 c$.

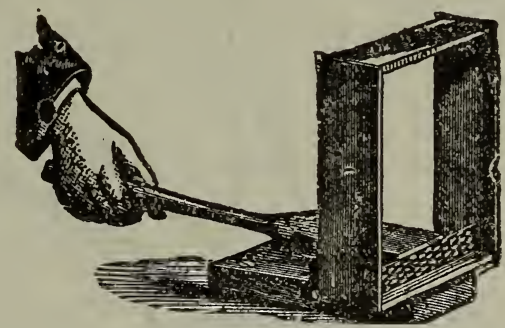

The point of lever should be moistened on under side with water or honey to prerent its sticking to the foundation.

\section{COMB FOUNDATION}

DADANTS

Extra thin surplus, per $1 b . \ldots \ldots \ldots \ldots \ldots \$ .65$

Liedium Brood, per $1 \mathrm{~b} . \ldots \ldots \ldots \ldots \ldots \ldots . .55$

Subject to Market Change.

SPECIAL PRICE IN QUANTITIES.

\section{SUNDRIES.}

A. B. C. of Bee Culture ............. \$ 1.25

Cowan Reversib?e Honey Extractor-two

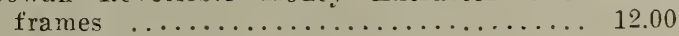

Bee Vails, No. $4 \ldots \ldots \ldots \ldots \ldots \ldots \ldots . .25$

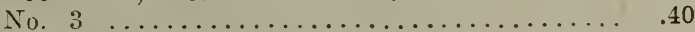

$1 / 2$ lb. Spool No. 30 Tinned Wire ........... .20

1 lb. Epool No. 30 Tirned Wire ............ 30 


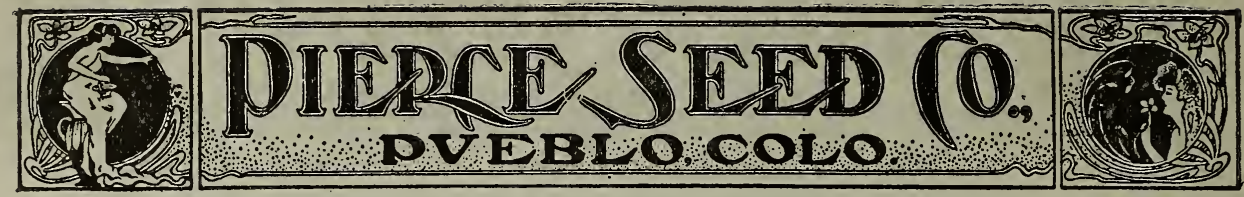

IRON AGE GARDEN TOOLS

\section{No. 1. IRON AGE DOUBLE AND SINGLE WHEEL HOE}

PRICE, COMPLETE, $\$ 7.00$

WEIGHT, PACKED, 40 POUNDS

The wheels are made of steel, very light and are 16 inches in height.

The frame is made of tubing, coupled to malleable eastings, high arch, eapable of working astride 20 inch plants.

TOOLS-With the tools that go with this Wheel Hoe it is adjustable to any work required in a garden.

No. 13, with side hoes and teeth only.....\$5.50

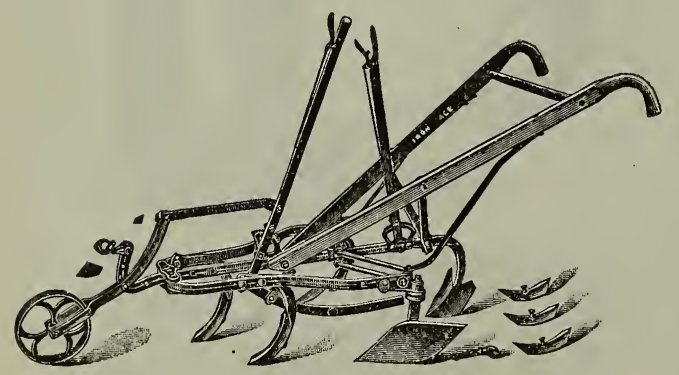

\section{No. 6 IRON AGE HORSE HOE AND CULTIVATOR}

The frame of this tool is high and long, adjustable to width and depth; with lever expander and lever. wheel.

WEIGHT, PACKED, 83 POUNDS PRICE, AS PER CUT, \$6.25.

\section{No. 6 IRON AGE COMBINED}

\section{DOUBLE AND SINGLE HOE,}

\section{HILL AND DRILL SEEDER}

Whee's 16 inches high, tires $11 / 4$ inches wide. Weight, packed, 57 pounds. From Seed Drill this tool can be converted into Wheel Hoes, Double or Single, and adapted to any use for a garden tool. Price, $\$ 12.00$.

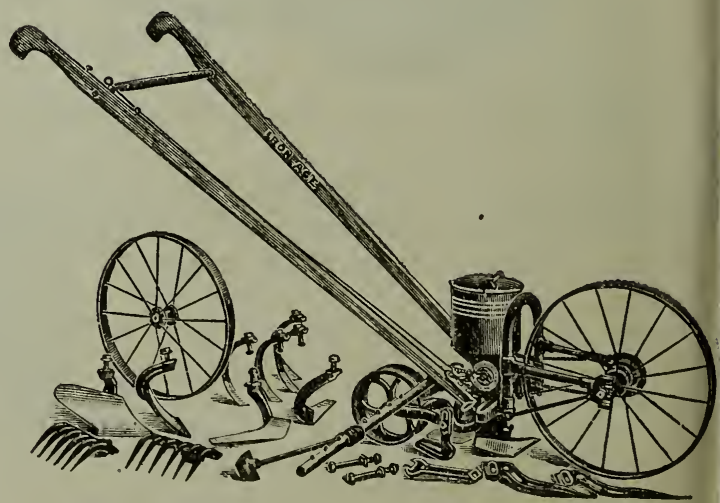




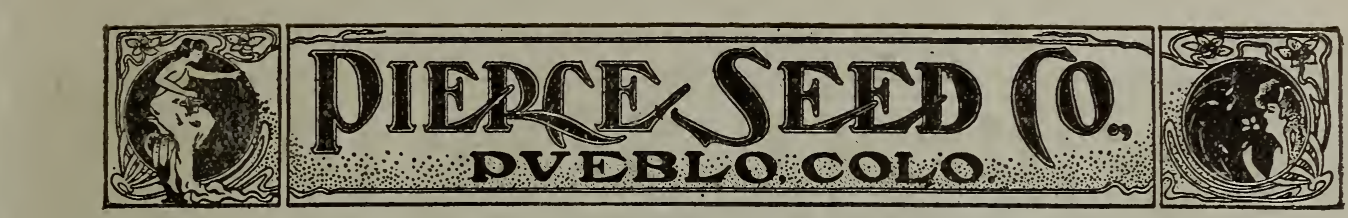

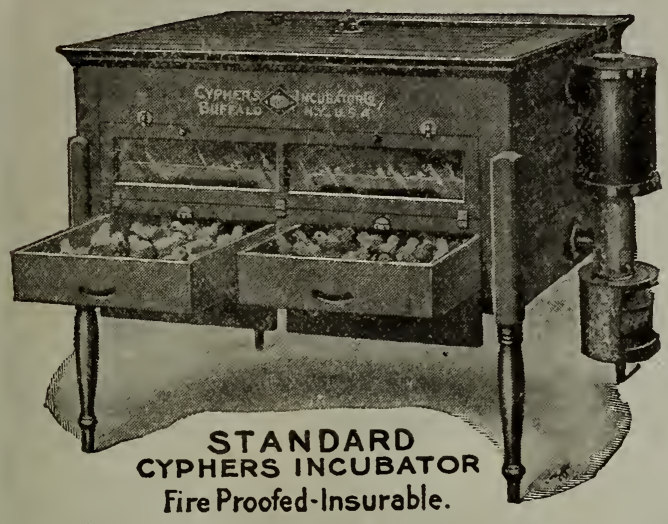

\section{Cyphers Incubators}

No. $0-60$ Egg Size $\ldots \ldots \ldots \ldots \ldots \ldots \ldots 15.00$

No. 1-144 Egg Size ............... 22.00

No. 2-244 Egg Size .............. 32.00

No. $3-390$ Egg Size $\ldots \ldots \ldots \ldots \ldots \ldots \ldots . \ldots \ldots$

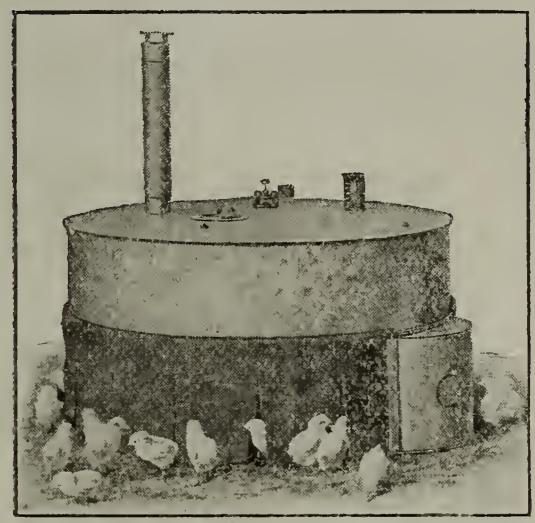

Cyphers Portable Hover

Shows the Cyphers Portable Hover in use on floor of poultry house. Chicks at all times are on a level with the surrounding floor.

PRICE, $\$ 8.50$

SEND FOR DESCRIPTIVE CIRCULAR OF CYP HERS INCUBATORS, BROODERS AND HOVERS

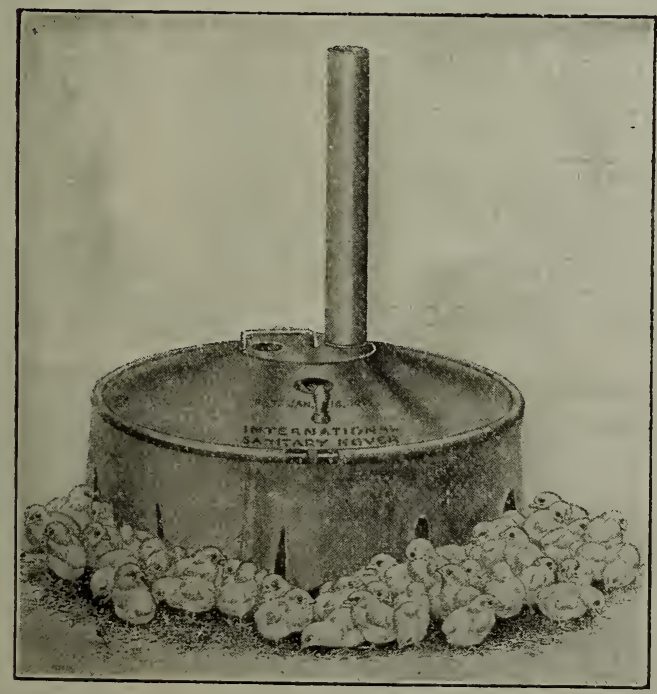

\section{International Sanitary Hover}

\section{HOVERS 100 YOUNG CHICKS.}

You can raise your chicks with this hover. Send for descriptive circular.

\section{PRICE F. O. B. PUEBLO, $\$ 8.50$}

Those who used this Hover last season were more than pleased. 

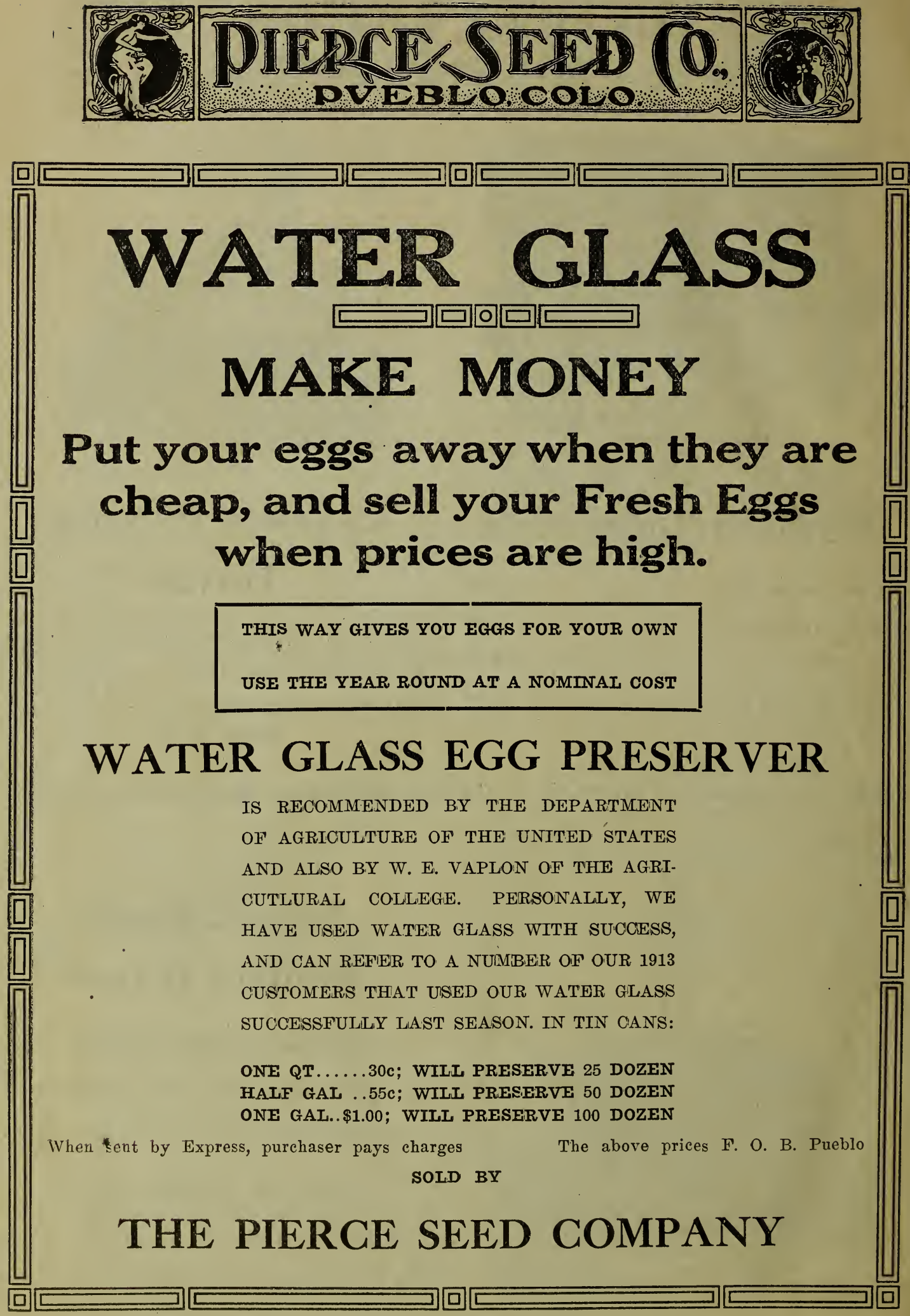


\begin{tabular}{|c|c|c|}
\hline $\begin{array}{l}\text { With } 5 \text { inch 3-pl. } \\
\text { one Borge h } \\
\text { Gozzle. } \\
\text { Giant Brass } \\
\text { Complete with } \\
\text { hose and Bor- } \\
\text { deaux nozzle, } \\
\text { malleable foot } \\
\text { rest. } \\
\text { Price } \\
\$ 3.50\end{array}$ & $\begin{array}{l}\text { FOUNTAIN COMPRESSED } \\
\text { AIR SPRAYER } \\
\text { One of the best Knapsack spray } \\
\text { pumps. Has check valve at handle, } \\
\text { giving complete control of the spray. } \\
\text { Five-gallon galvanized tank. Price, } \\
\text { t6.50. } \\
\text { MYERS IMPROVED } \\
\text { BARREL SPRAY PUMP } \\
\text { Complete with 5-ft. 1/2 inch 3-ply dis- } \\
\text { charge hose, Bordeaux nozzle. } \\
\text { Price ...................... \$10.00 } \\
\text { With Mechanical Agitator ...... \$11.00 }\end{array}$ & $\begin{array}{l}\text { Myers' Lever Bucket } \\
\text { Spray Pump } \\
\text { Complete } \\
\text { with hos e } \\
\text { and Bor- } \\
\text { de a u or } \\
\text { Vermore l } \\
\text { nozzle. } \\
\text { Price } \\
\$ 6.00\end{array}$ \\
\hline
\end{tabular}




\section{Dwarf Yellow Milo}

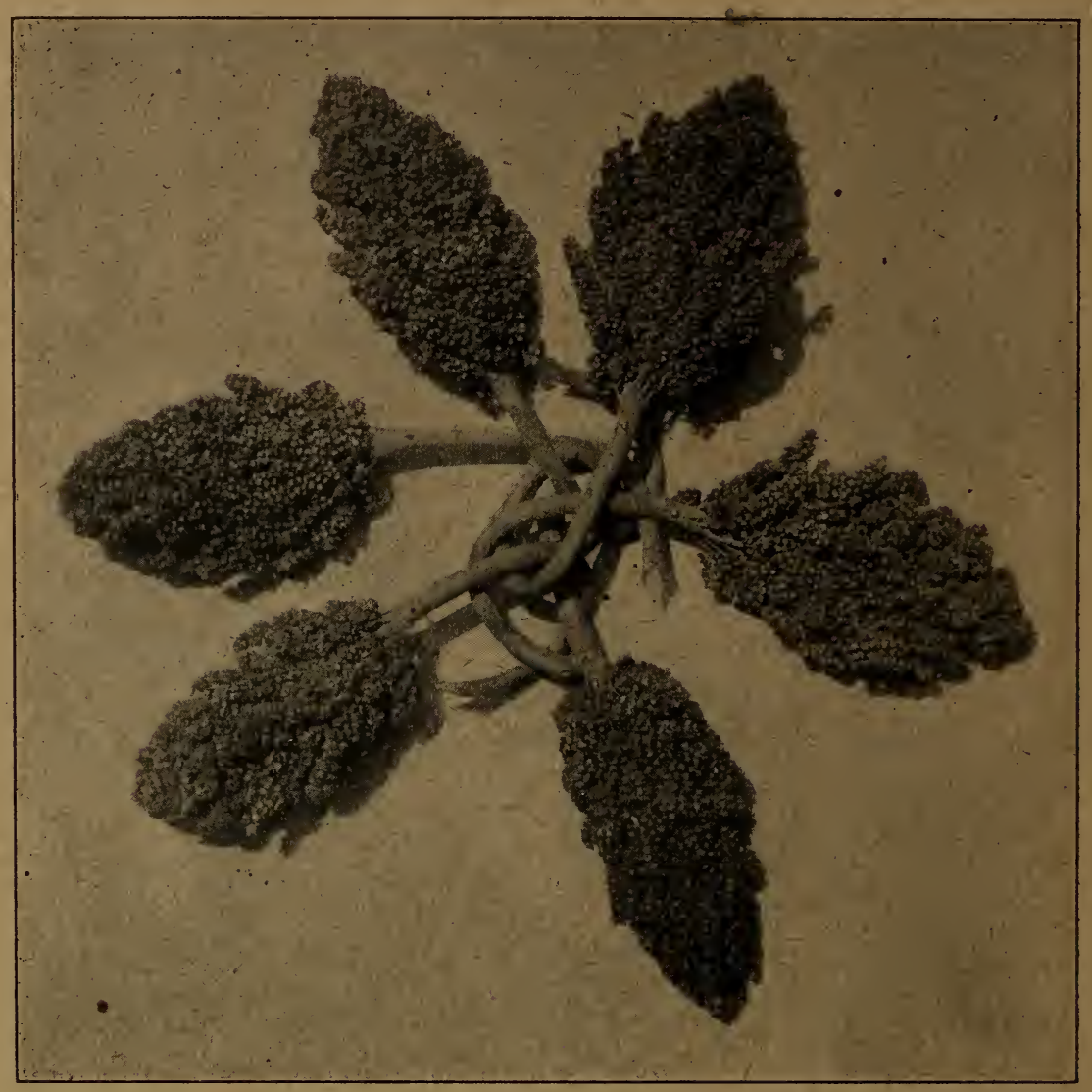

\section{Will Grow With Less Moisture Than Any Other Crop You Can Sow or Plant}

YELLOW MILO MAIZE (Dwarf)-This is one of the best varieties of grain for non-irrigated land. It withstands the drouth better than any other crop and unlike most grain, does not die out but stands dormant after starting until revived by rain, and grows very fast in the hot summer months. The yield is from 30 to 40 bushel per acre; its feeding value 90 per cent of shelled corn. The dwarf variety is the only kind to grow in Colorado, and is the kind we offer. Plant in rows from two to three feet apart, six to eight pounds to the acre, cultivate and give it the same care that you would a crop of corn. The seed that we offer is Colorado grown. Market Price. 